$$
\begin{aligned}
& 5537 \\
& .085 \\
& 1915
\end{aligned}
$$





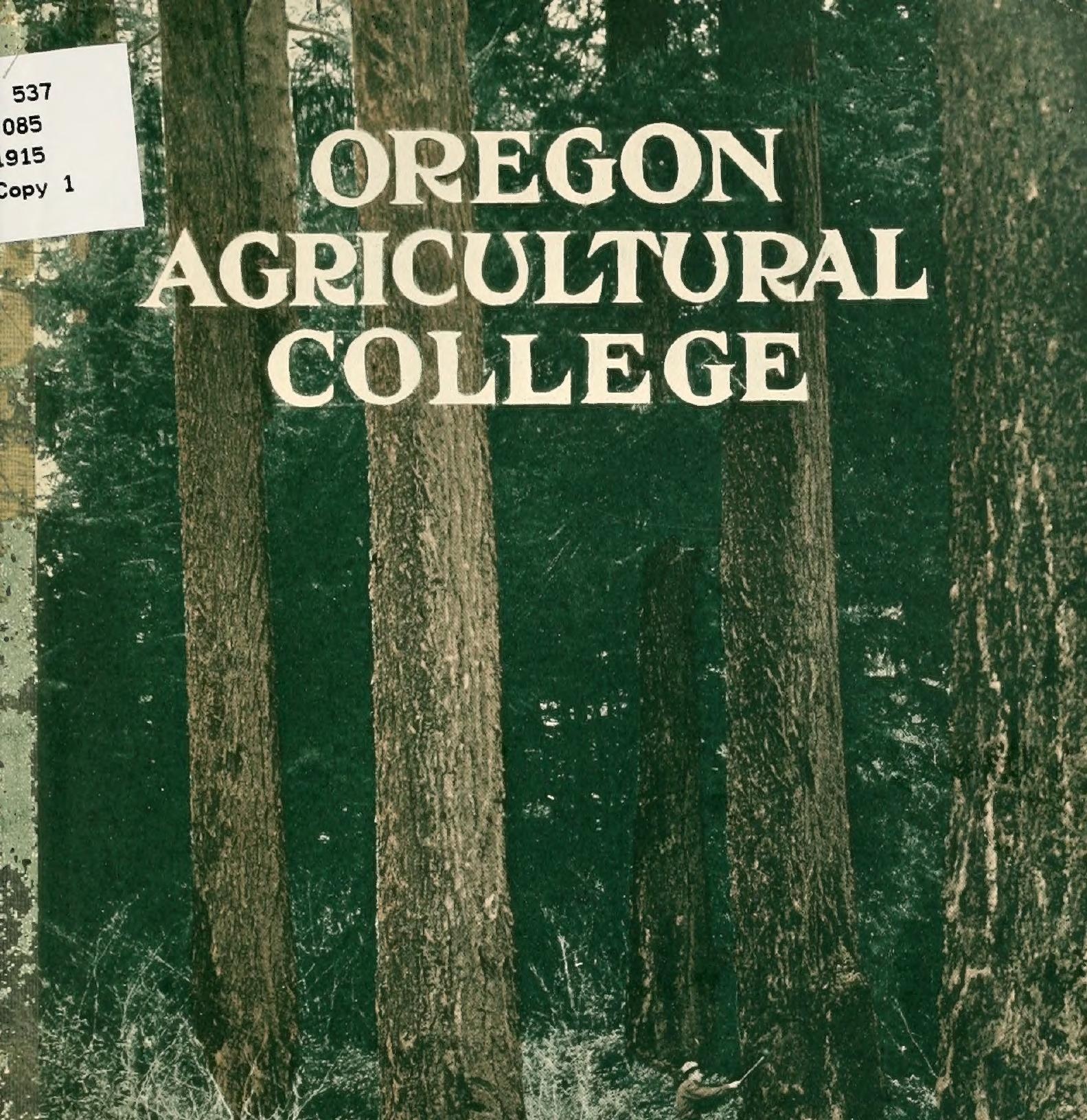

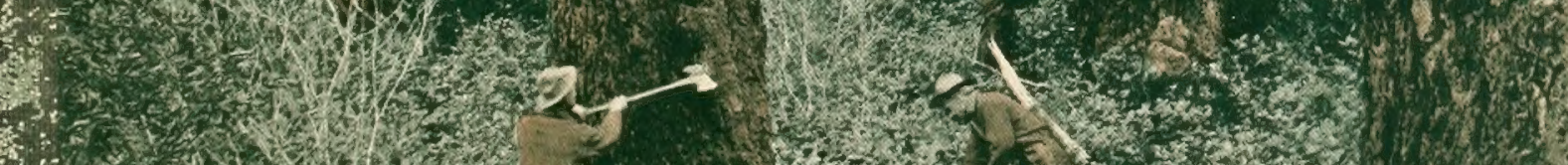
(3) (2)

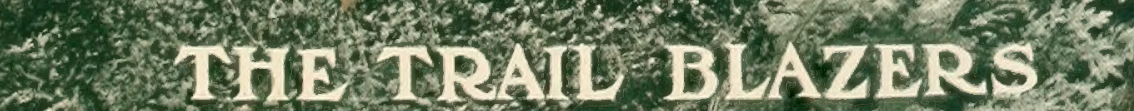

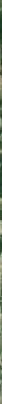




$$
\begin{aligned}
& 537 \\
& 085 \\
& 1915
\end{aligned}
$$

D. 解

OCT $12 \quad 1915$

$\therefore \vdots$ 


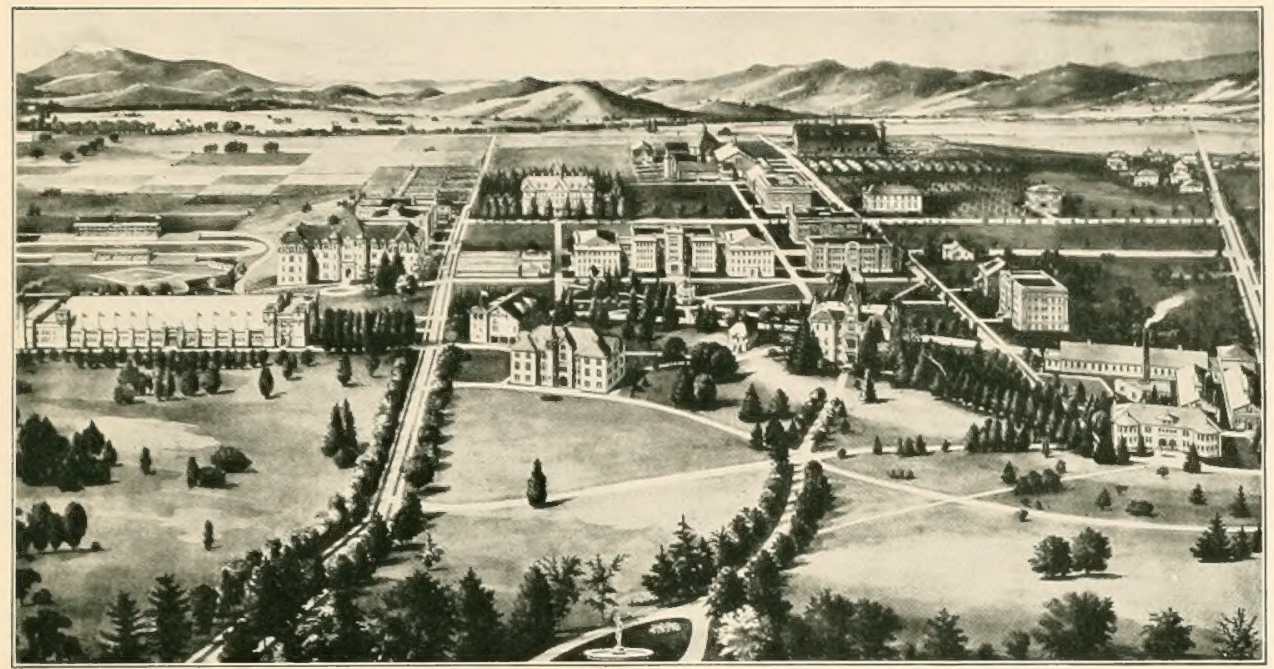

BIRDSEYE VIEW OF THE COLLEGE CAMPUS

THE TRAIL BLAZERS.

The trail blazers, since wilderness was king, have been the men and women who have led the way to new fields of endeavor. They have been the pioneers who have pushed back the frontiers of human experience. In the realm of territorial space,

\section{Work of the} Trail Blazers.

by superior courage, confidence, and perseverance, they have held their courses through a series of perils as triumphant in their conclusion as they were picturesque and thrilling in their performance. In the realm of industry and science, they have braved the sneers of the incredulous and the hatred of the superstitious, in a long and plodding struggle toward the saving of human labor and the widening of human vision. In the realm of government and social service, they have left behind them, through their self-effacement and heroic sacrifices, institutions that have lifted the race to higher levels of happiness and holier heights of spiritual responsibility. The trail blazers, in short, have been the progress-makers of mankind.

In the past, mere discovery of material resources, often of titanic proportions, made up the most startling and revolutionary contribution of those who left the beaten path and broke a trail into the Great Unknown. The revelation in the

In Past

Centuries. accounts of such navigators as Vasco Da Gama, the Cabots, De Soto, and La Salle, unrolled before the eyes of the world intoxicating possibilities of expansion. Daniel Boone blazed a trail from North Carolina to Kentucky, and soon the inland wilderness was dotted with the homes of settlers. Lewis and Clark, in their expedition from the 


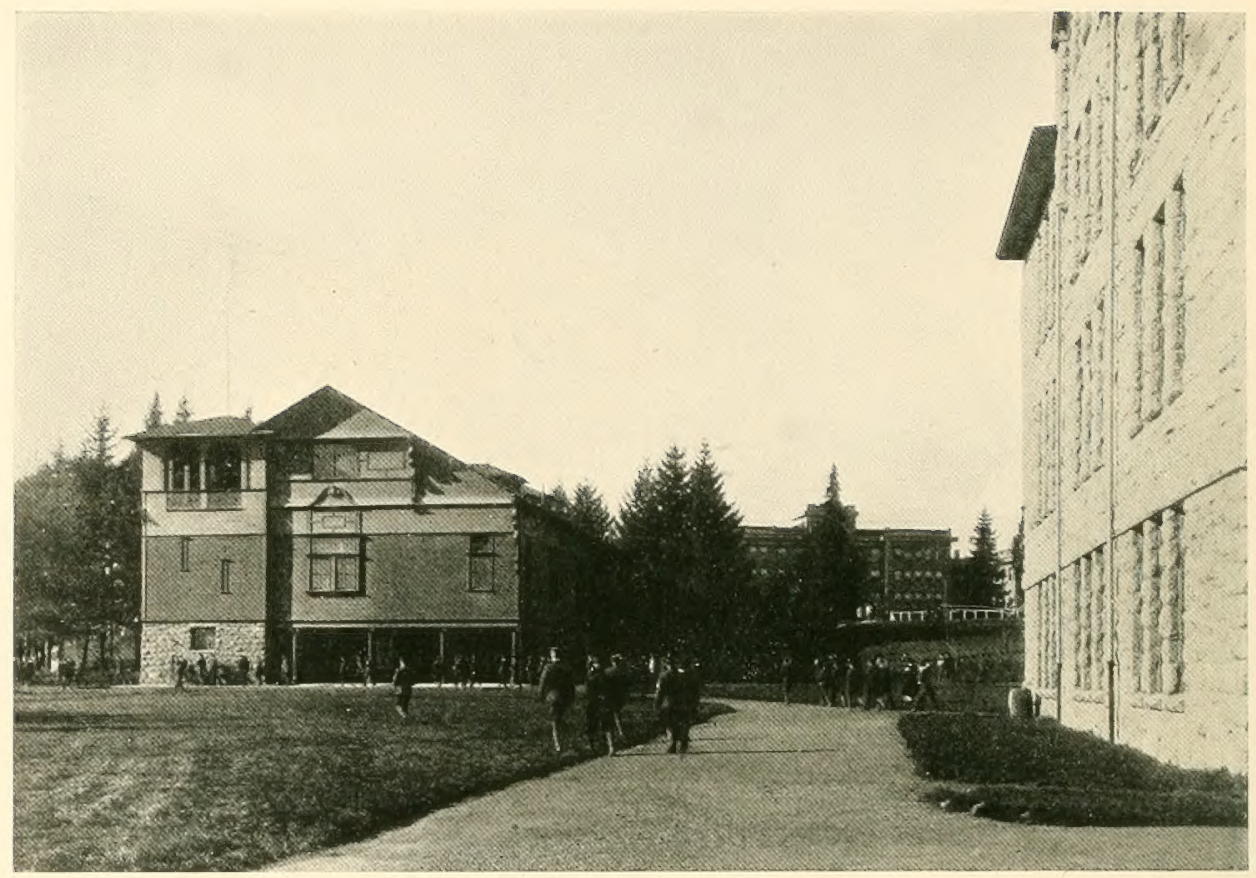

WOMEN'S GYMNASIUM FROM SOUTH END OF SCIENCE HALL

mouth of the Missouri to the mouth of the Columbia-4,134 miles as they made it, through the great Lone Land and over the Rockies - added to settlement the enormous area of half a continent. Along their route, which is today traversed by a great trans-continental railroad, ten states, with a population of fifteen millions, have been erected.

While the trail blazers of today have fewer physical triumphs to achieve on a vast scale than the discoverers of yesterday, their field of operations is still ample, and their services are quite as necessary as of old in redeeming their In the Present Century. contemporaries from the ruts of conventionality. There are no more continents to discover, it appears, yet the courage and persistence of a Columbus may even today penetrate as far into the unknown, and accomplish as momentous results, as the famous voyage of 1492. No captive nation may just now be fleeing out of Egypt to its promised land; yet a modern Moses in the person of Booker Washington may do as much for the redemption of his people in bringing them from degradation to manhood, from bondage to independence, as the biblical leader of old. The thrill that Balboa knew, "silent upon a peak in Darien," may never again be vouchsafed to mortal man, yet a Pacific Ocean which would bear up the prodigious modern fleets of capital and labor, employer and employed,-aye, and the dreadnoughts and submarines of the Powers of the earth, and still be an ocean of Peace, would be a discovery as devoutly to be wished and as perpetually celebrated as the 


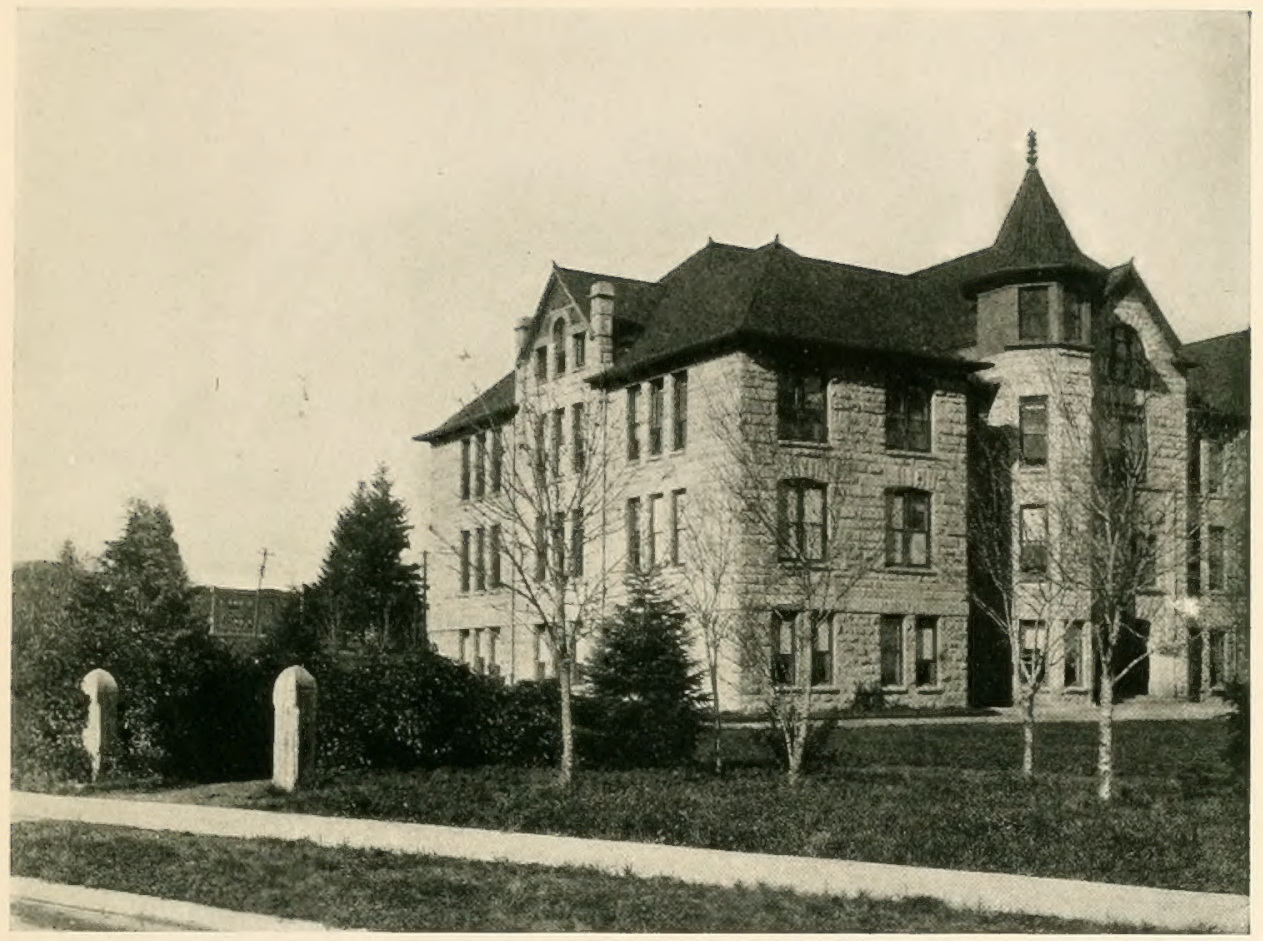

SCIENCE HALL FROM JEFFERSON STREET

achievement of the Spanish adventurer in 1513. There may be possible hereafter no mechanical invention as revolutionary in its effect upon industry as the reaper, the sewing machine, the cotton gin, the linotype, or the steam engine, but some system or device which would reduce the drudgery of the housewife or solve the problem of cheap transportation, whereby the desirable products that go to waste in one section of the country may be exchanged for equally desirable products raised in excess in some other section, would make immortal the name of its originator. No instrument to eclipse, in its own field, the telegraph, clicking off at lightning speed, from continent to continent, the thoughts of men; or the telephone, carrying the human voice, in a spark's duration, from ocean to ocean; or yet the wireless telegraph, whispering through the impalpable ether its doleful warning or its thrilling relief, may ever be added to the mechanical triumphs of the twentieth century. But wise men tell us - the elders of our time, octogenarians, sobered by the limitations of human achievement, yet decorated with the richest emblems of distinguished deeds - these men tell us, in all reverence, that one of the probable attainments of the present century will be intelligible communication with the other planets, possibly with the lower animals, surely with the souls of the departed.

Chimerical do you say? So said the contemporaries of Copernicus when he announced his theory of a sun-centered universe; so said the skeptics in Field's 


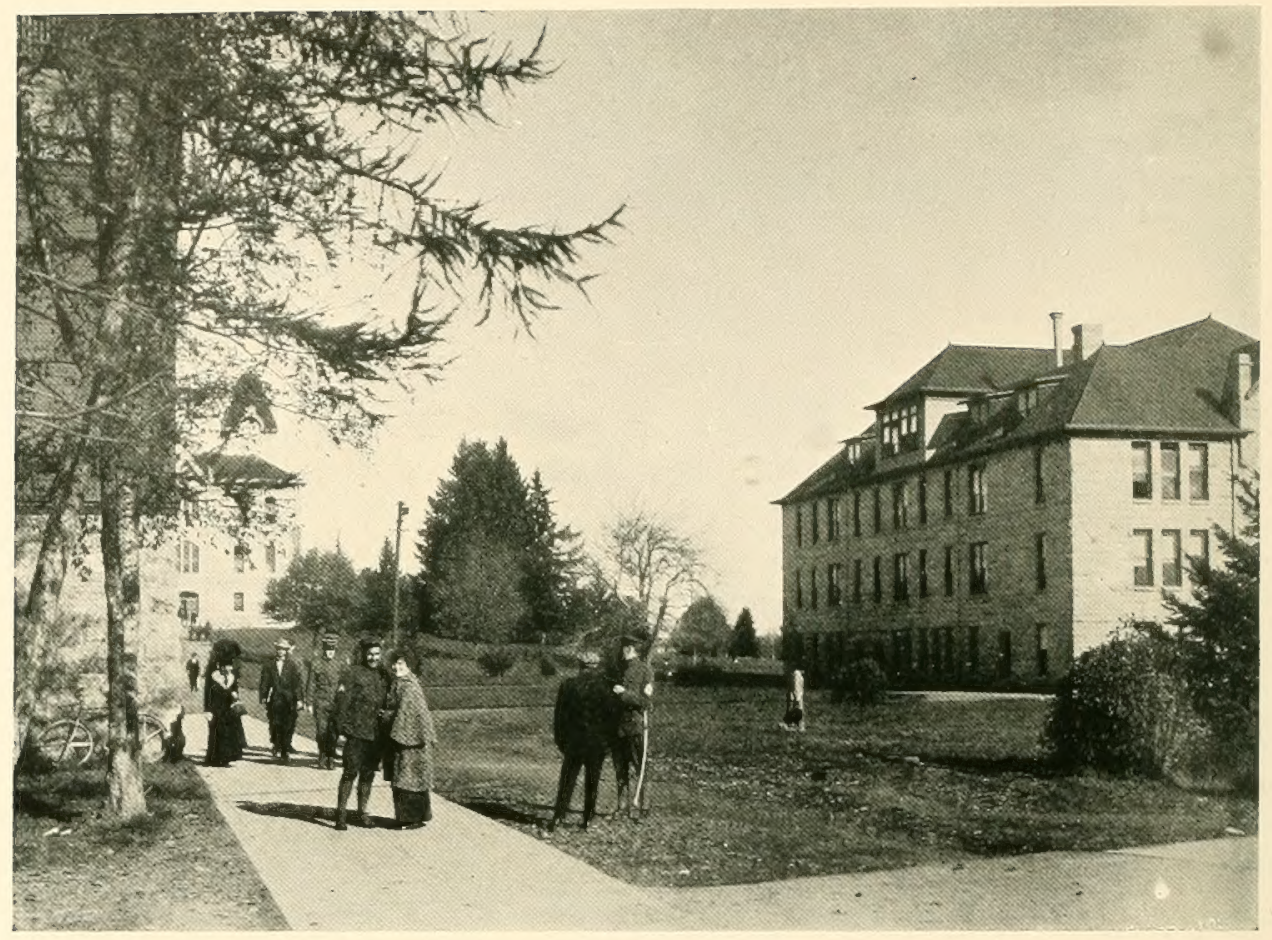

TH E "GYM" PATH ON A WINTER AFTERNOON

day, when he crossed the ocean fifty times in his effort to lay the Atlantic cable;

Doubts of

Yesterday and

Today. so said our complacent elders in the days of our boyhood when the fascinating adventures of the Nautilus, "Twenty-thousand

Leagues Under the Sea," or of the cloud-topping air-ship in

Tom Sawyer, prompted us to inquire, with wide eyes, if it ever had been done, if it really could be done, and we received in answer a tolerant smile or an indulgent reference to "Darius Green and his flying machine." But today these same tolerant old people are zealously scanning the news columns for the expected account of a Zeppelin raid on England, or trying to keep up with the fabulous submarine warfare of the indomitable $\mathrm{U}-16$.

No; there's no use repeating Mrs. Partington's reactionary experiment with the broom, however impelling the energy of our doubts; for the tides of a prodigious future will continue to break over our little barricades of present achieve-

Routed by

Achievements of Tomorrow. ment and pile them up into the majestic mountain peaks of tomorrow. In the past century there was a greater advance in the condition of human life than in all the preceding one thousand years. Who shall say that the twentieth century will not bring changes ihat shall eclipse those of the nineteenth, even as those of the nineteenth century eclipsed those of the eighteenth.

A century ago there was but an occasional investigator, solitary, working on his own resources, with only the most desultory contact with what had gone 


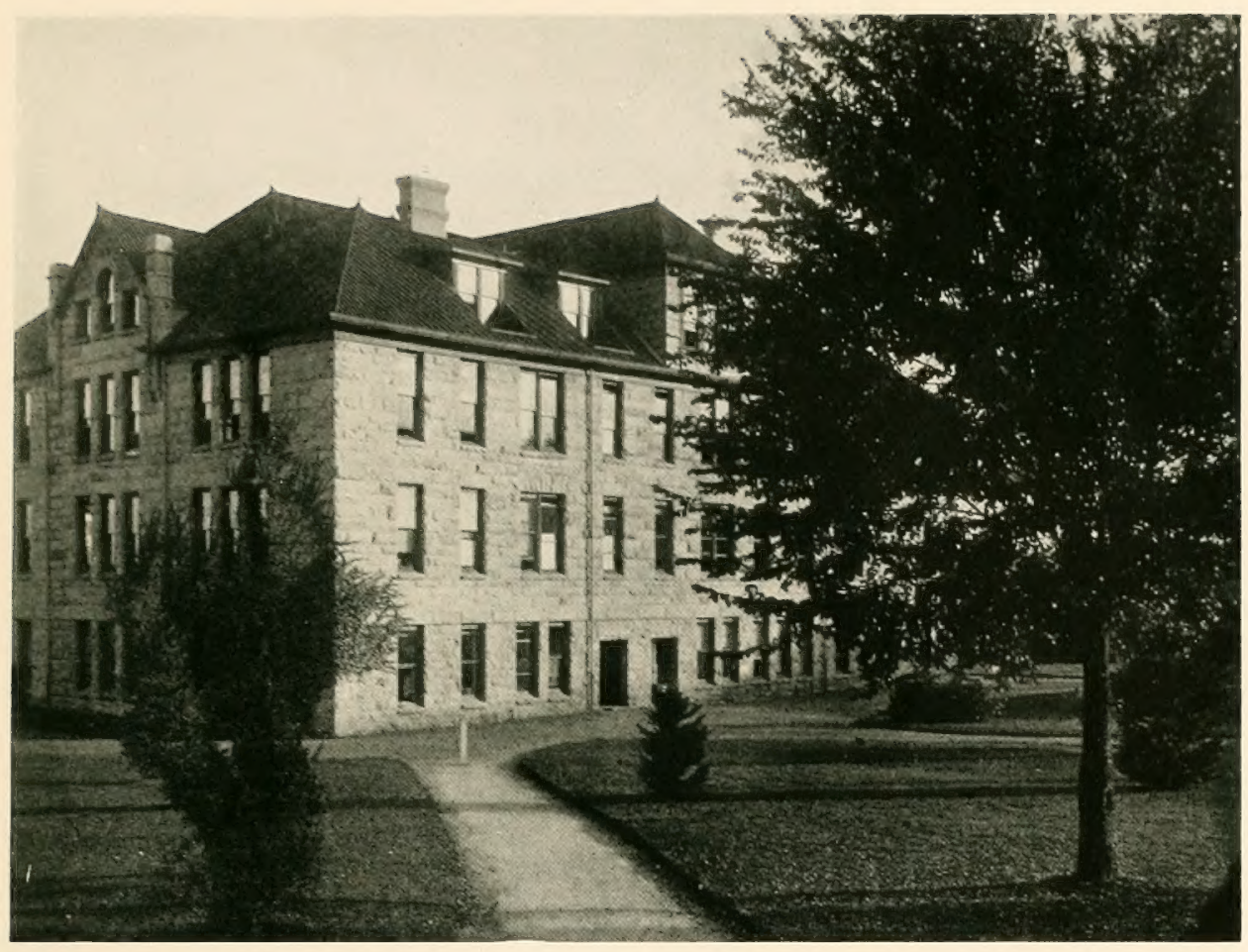

SCIENCE HALL FROM ADMINISTRATION PATH

before; today there is an unorganized army of research workers, backed by the authority of the most august and responsible scientific associations, whose accumulated stores of information are available to all competent inquirers, and supported by adequate funds provided by private endowment, state appropriations, or federal donations.

So comprehensive and so responsible has scientific investigation become, that a working knowledge of the future is a possible and practical thing. Science, in its observation of the laws of causation, has rapidly reached the stage where

Forecasts of the Future. it can offer forecasts of the future as confidently and as accurately as it can chronicle the happenings of the past. The United States Weather Bureau is a comparatively recent evolution. Beginning as a branch of the War Department, it served at first only to give warning of threatened storms along the seaboard. Today, an independent bureau of the Department of Agriculture, it forecasts the weather conditions of the entire country, giving warnings of frosts, as well as storms, and guiding by its daily bulletins not only the momentous operations of commerce, but the complex activities of a national agriculture. It does not simply collect statistics and publish conditions of fact, though these are responsible and valuable functions of the bureau; it analyzes facts and deduces probabilities. In other words, it foretells the future; it prophesies. 


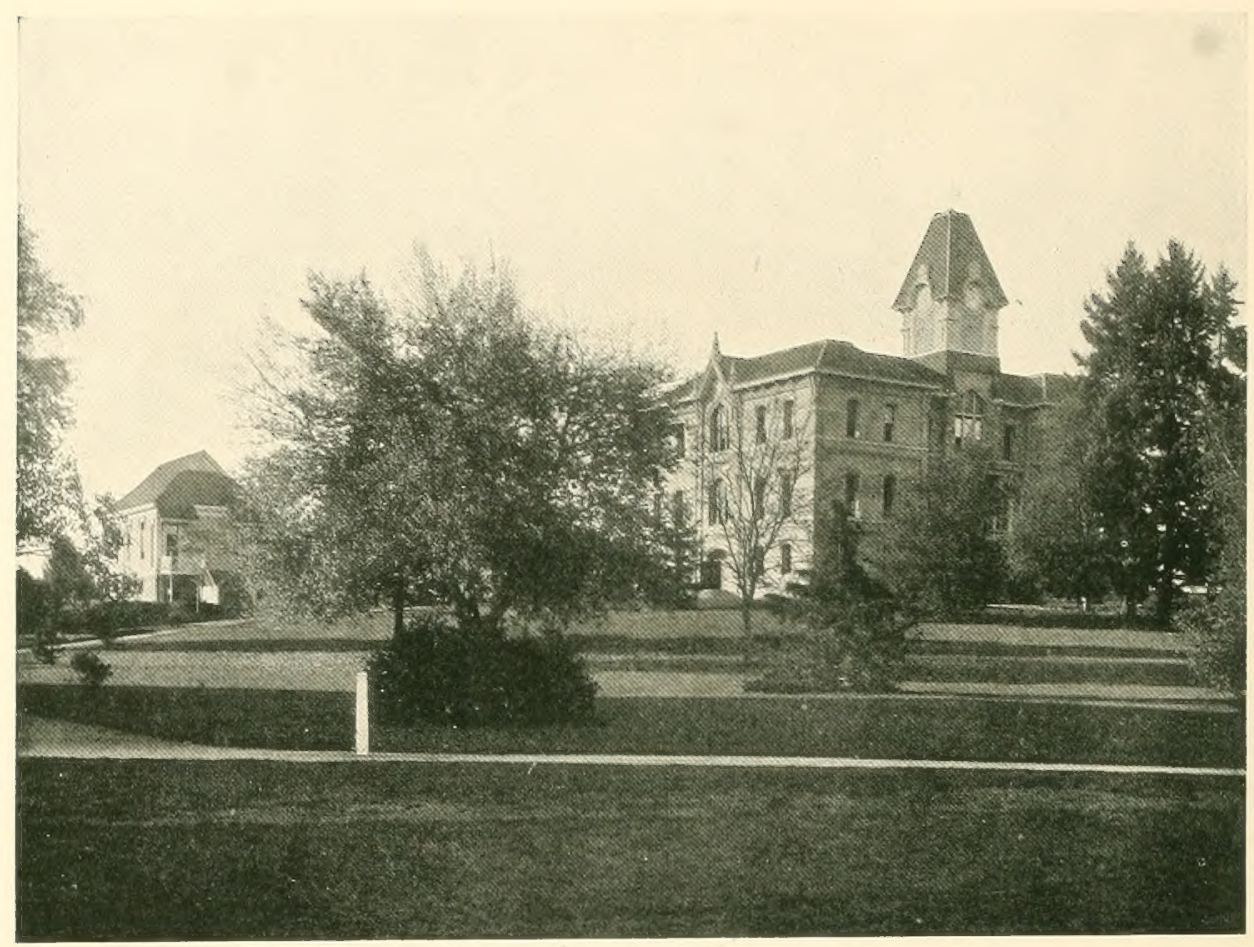

ADMINISTRATION BUILDING AND COOPERATIVE STORE

Any science of today, in fact, that is worthy of that distinguished name, is capable of predicting the future. The Entomologist knows the life-history of the crop enemies of his particular field; he knows the general behavior of crops

Predictions of Science.

under the soil and weather conditions of his field; and he knows the special poisons, preventive measures and precautions best calculated to kill the insect pest and foster the growing crop.

So he prophesies. And in the great majority of cases, the man who heeds the prophecy is the one who raises the crop, while his incredulous or shiftless neighbor harvests nothing but husks and insect enemies. The Horticulturist - familiar with the laws of plant breeding, with its persistent tendency to transmit hereditary characters, but with its variations, "sports," and reversions - can cross and recross varieties of plants that he desires to modify, and even take short cuts by way of selection, and still quite confidently predict the resulting fruit or flower, though his hybrid plant may be many years in coming into blossom or bearing. The Animal Husbandman, scientifically trained in the principles of breeding, and expert through experience in determining the prepotency of his animals, as well as the dominant characters he wishes to transmit, rigidly keeps in view the ideal he would ultimately establish, and works with security, albeit with indomitable patience, toward the goal that is the fulfillment of his prophecy - a superior and distinctive type of animal. 


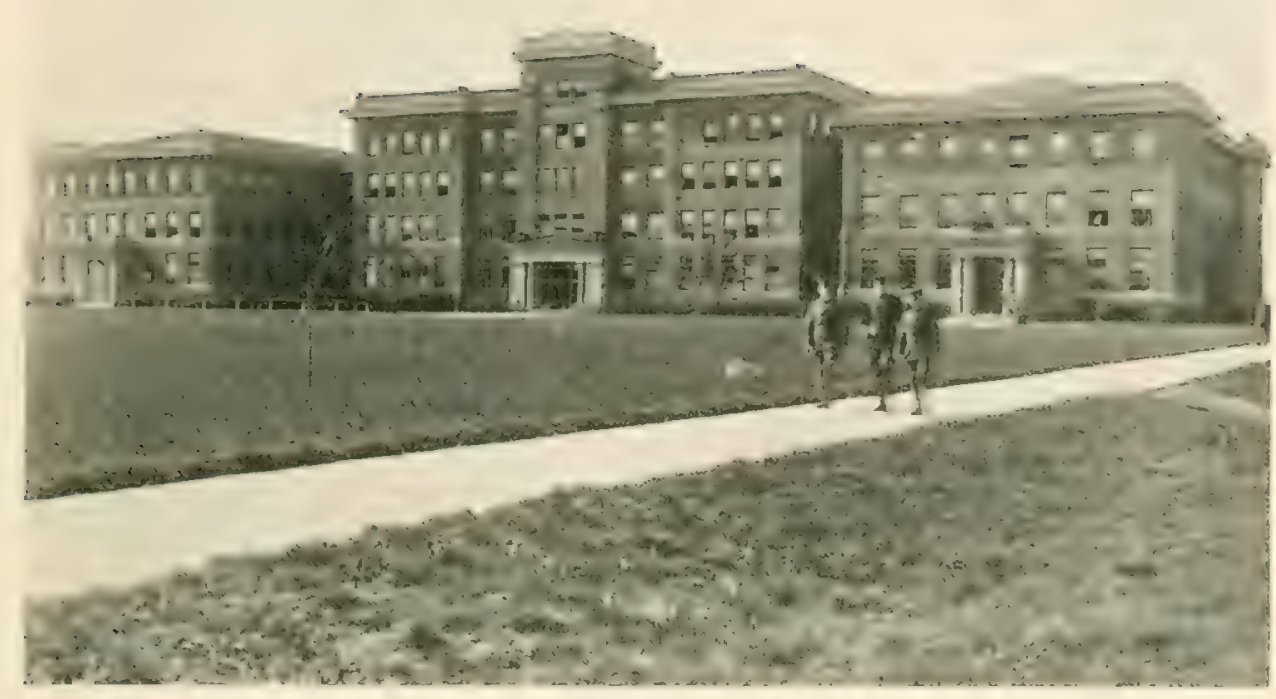

AGRICUITURAL HALL.

And thus throughout the realm of science, prophecy is the test of integrity. The astronomer foretells with mathematical precision the recurrence of eclipses and comets. The soil analyst, bringing to his aid the sciences of physics, chemProphecy, the Test of Science. istry, and bacteriology, prescribes the fertilizer, as well as the sort of treatment, that will bring definite results with specified crops and cropping practices. The Agricultural Chemist, having analyzed the most desirable type of cured hops and thus determined the constituents necessary to perfection, studies the processes of curing, as well as the time and method of harvesting hops, and from this data, together with his acquaintance with the soil and climate, prescribes the program for arriving at the coveted goal. The science that cannot predict results, in fact, is frankly open to suspicion.

Exceptions, do you say? 'True. There are possible exceptions, also, to the wisdom of obeying the ten commandments, and nature herself is no stickler for pure mathematics; but these peculiarities do not invalidate the working of the decalogue or the laws of the natural universe.

The fact is, that the principles and practices of modern production. manufacture, and distribution have been pretty completely reduced to a science. Big Business was quick to recognize this fact, and rallied to its aid all the wizardry of the scientific specialist and his laboratory, assured, both 


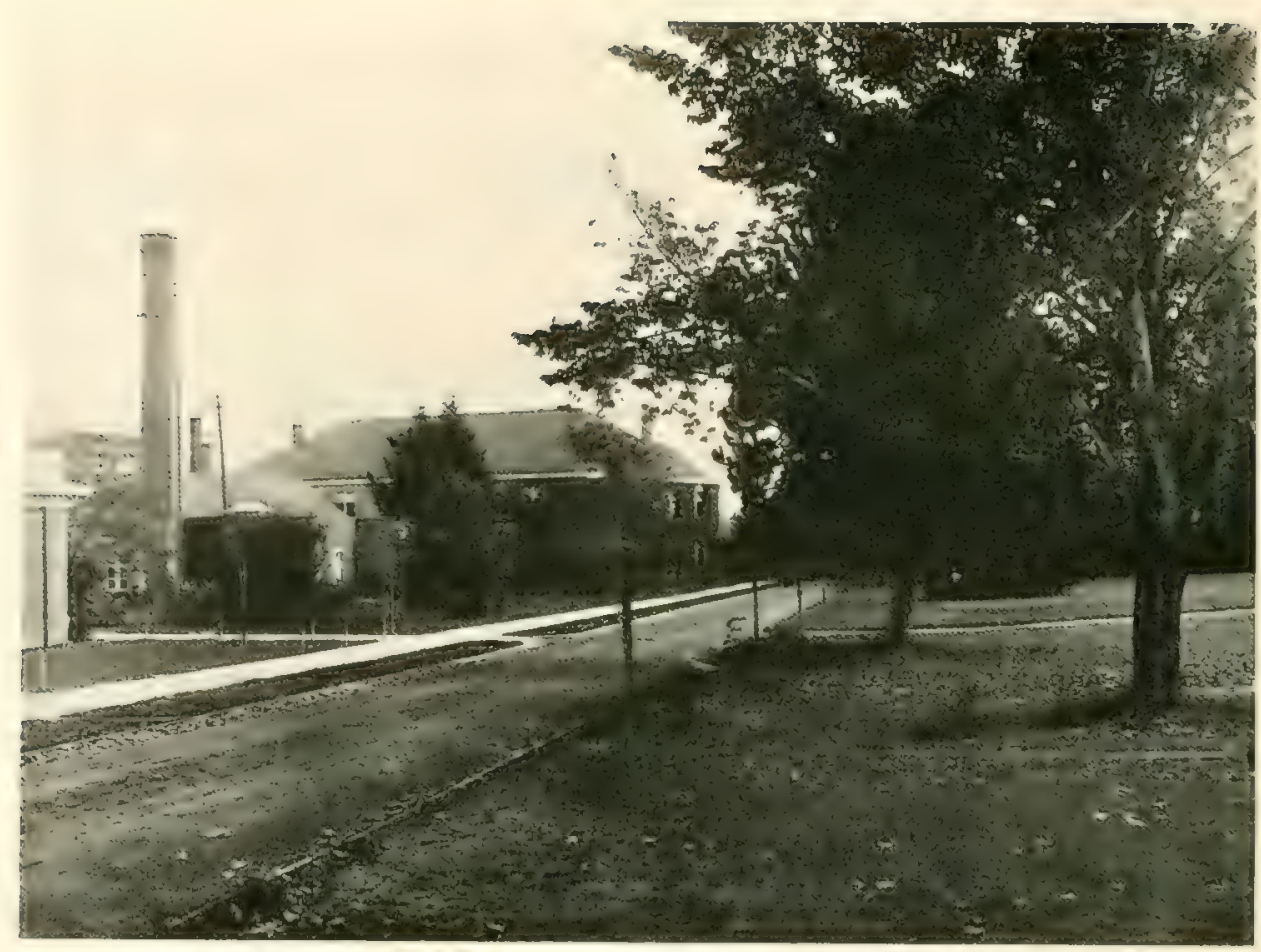

THE OLD HEATING PLANT AND MECHANICAL HALL, COLLEGE-BUILT DRIVEWAY IN THE FOREGROUND

by theory and by actual practice, that the procedure would pay. And it has paid. Indeed, we are told, on the best authority, that the scientific utilization of the by-products of such an industry as meat packing or cotton manu-

Big Business facturing, produces an annual revenue sufficient to pay the Gains by Science. interest on the investment. These by-products, moreover, were not merely waste, they were worse than waste-an absolute menace to public health and comfort. Out of worse than nothing science has created self-support.

The forces of commerce and even of merchandising have also been prompt enough to seize upon the teachings of science, even to the point of obeying the dictates of psychology and economics, neither of which is yet secure in its aspira-

\section{The Producer} tions for scientific accuracy. But both commerce and merchanHas Held Back. dising, in spite of severe restrictions imposed upon them by legislative enactments, have succeeded better under this kind of tutelage than ever before in the history of trade. Only the producer, more especially the farmer, has been indifferent to the warnings and promises of science, or has been reluctant to put his faith in them. In spite of the most immediate, concrete, and substantial assistance on the part of the Federal government, and in spite of a gencrally favorable attitude on the part of the state and local governments, the farmer has been last to be reached, last to be moved, and yet last to be given up. 


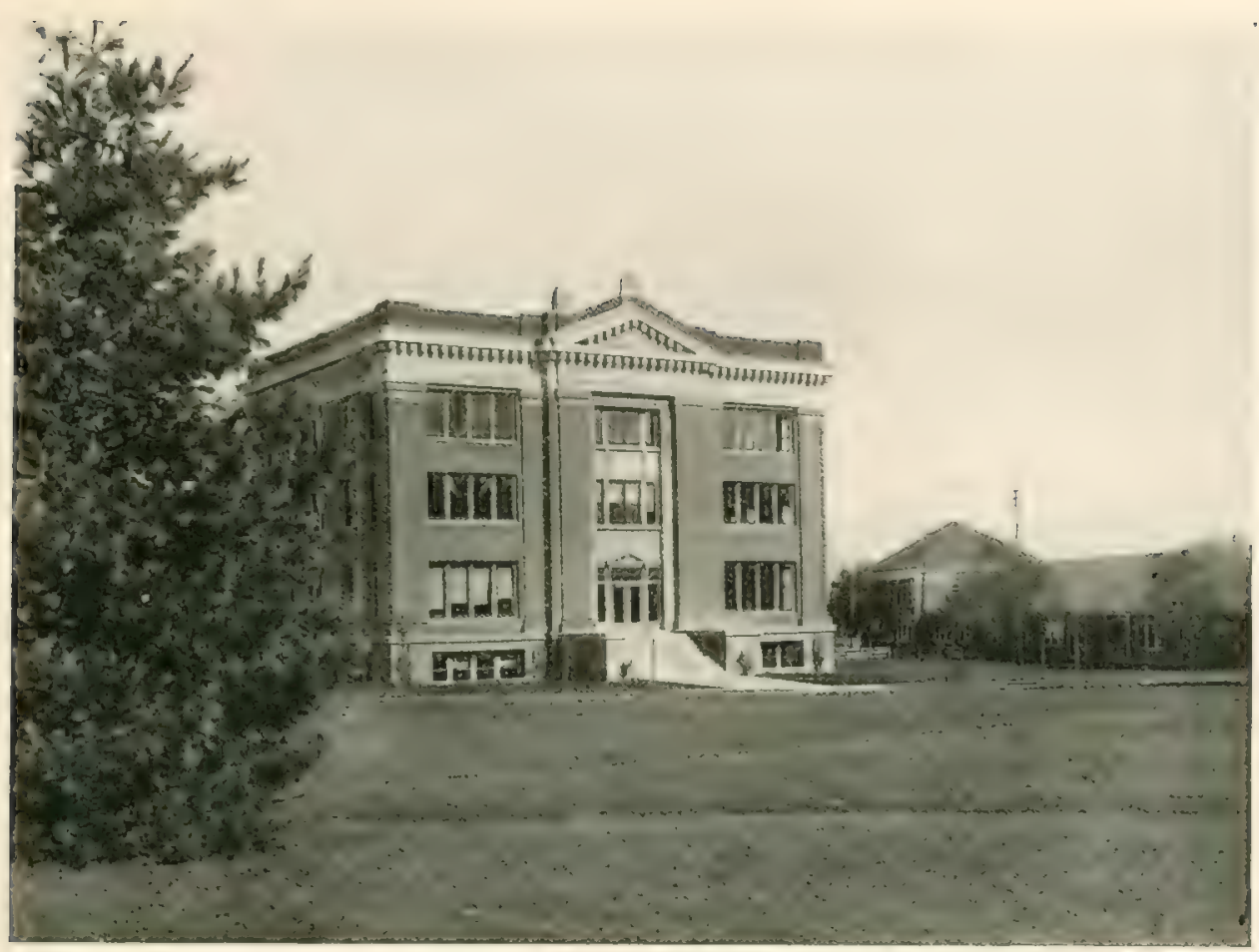

THE MINES BUILDING, WITH WOODWORKING SHOPS IN BACKGROUND

He cannot be given up. The whole splendid superstructure of American civilization, with its cities, its railrouds, its smoking manufactories, its engineering feats, and its prodigies of invention, will collapse in dust at his feet the moment

The Farmer

Must Be

Reached. that he falls. That is why the helping hand is reached out to him all along the line from the whole height of the national congress and the multi-millionaire to the country bank and the village commercial club. It isn't charity that prompts this universal concern; it is intelligent self-interest, a plain case of ultimate bread and butter.

Grant explained very frankly that an army travels on its belly. So does a railroad system, a city council, a merchant marine, and a stove factory. So does all civilization, however complex or refined. Hence the blockade of German

Necessity for Food.

ports by the Allies, and the submarine girdle about the Tight Little Island. Where is Sunday's dinner coming from, and where is Tuesday's breakfast? These are paramount questions in the world today, and they are as pertinent to America as to Europe. When the general average of crop production is declining throughout the land and the average cost of production is increasing, it is high time that somebody harpooned that hard fact and held it up to the light for attention.

And at last the farmer is giving attention. He is giving attention, in the first place, by keeping records and counting the cost, a thing he formerly 


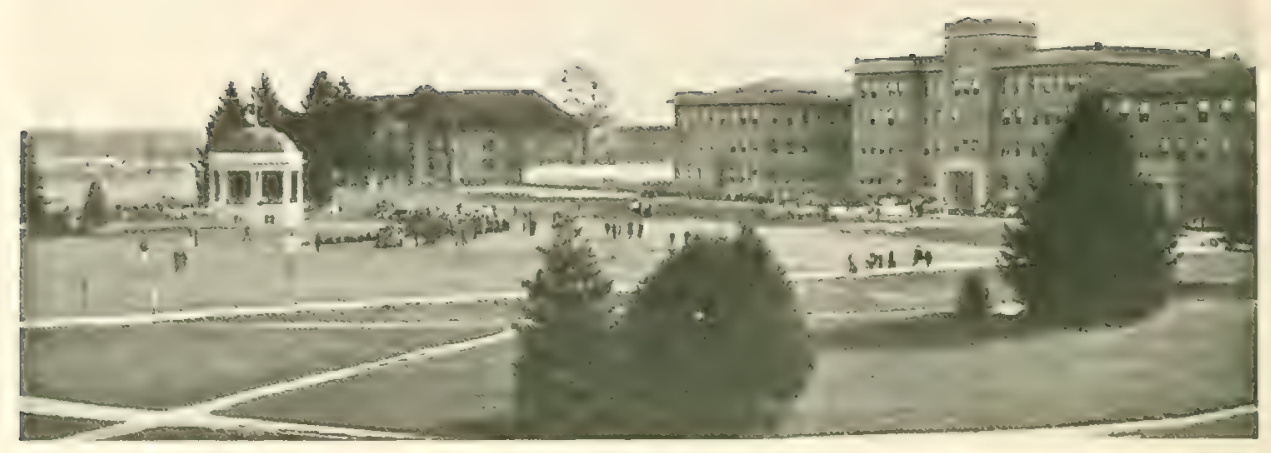

AN AFTERNOON BAND CONCERT

seldom did. He is giving attention, in the second place, by noting the kind and

The Farmer

is Giving

Attention. quality of products the market demands, and doing the grading himself. He is giving attention, finally, by evaluating his real estate at present worth, instead of at some ancient cost price; his hay and grain at market quotations, instead of as so much profitless produce to be fed to "boarding" animals without affecting either side of the farm ledger; and his own and his family's labor at prevailing rates of employment. $\mathrm{He}$ is giving attention to these things, in short, in counting the cost of his food stuffs, and he is looking for a decent compensation. In spite of the high price of food stuffs paid by the consumer, however, he is not receiving such compensation. In other words, he is not receiving a barely reasonable income for his investment and his toil.

The causes and the remedies for this situation, except in so far as they concern the initiative of the farmer himself, it is not the purpose of this booklet to discuss. It is enough to remark here that the problem is not exclusively the farmer's.

The Occasional Pioneer.
It is everybody's problem; for we are all either producers or consumers, or both; and in the end, no doubt, it will be everybody's problem to settle. But the agricultural college is concerned with it chiefly from the standpoint of the farmer and the home makerthe producer and the managing consumer. Here and there throughout the country a community is found that has already blazed a trail far along toward the settlement of this question, chiefly through cooperation and organization. Here and there in many communities an individual is found who is pioneering the may back to larger production and larger prosperity, chiefly through alertness in reading, in individual inquiry, and in appropriating the approved practices of the agricultural colleges and the United States Department of Agriculture. 


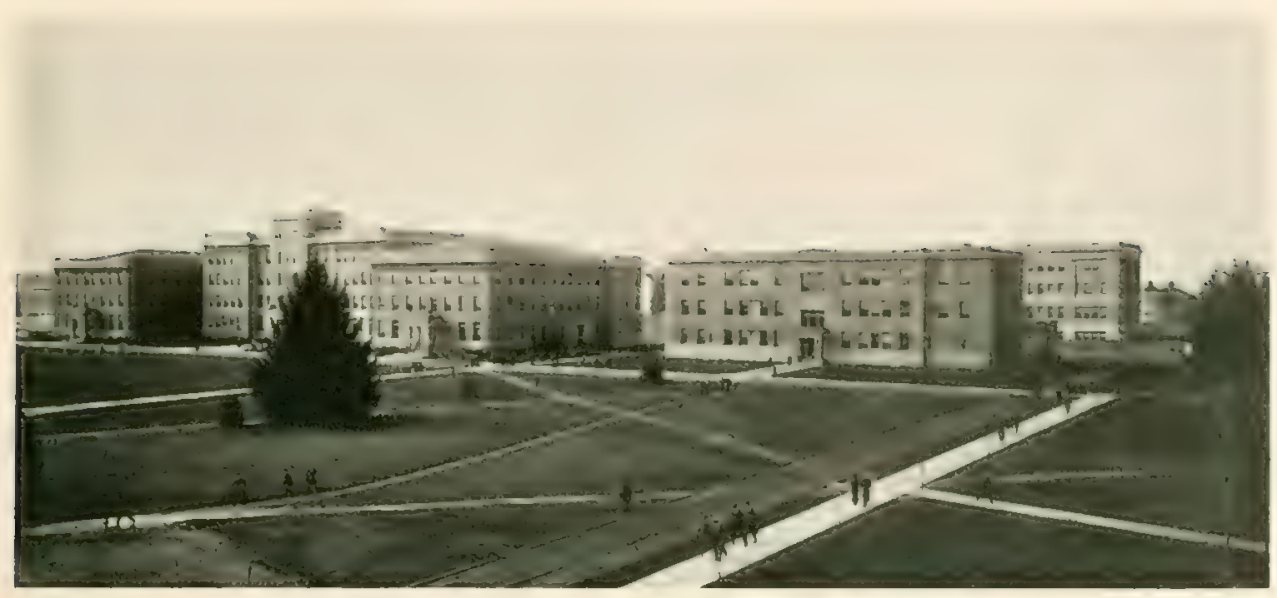

BETWEEN CLASSES ON THW LAST QUADRANGLE

For the chief factor in this whole movement, naturally enough, is the agricultural college. In cooperation with the Federal Department of Agriculture, it has been in the past, what it must become in still larger measure hereafter, the Agricultural Colleges the leader in the improvement of unused lands, in the utilization True Leaders. and conservation of natural resources, in the rejuvenation of worn-out soils, in the production of more varied and more abundant crops, in the distribution and marketing of products, and in the enrichment of the whole range of life on the land. This involves a wide field of effort and enlists the services of all the sciences. It was just such a field, however, that the conception of the founder of the land-grant colleges had in view. For Justin Smith Morrill, the American path breaker for a nationally endowed industrial education, and one of the greatest beneficiaries of agriculture that the nation hats ever known-next to the author of the national homestead bill, probably the greatest-conceived these institutions not merely as trade schools, nor yet as exclusively agricultural colleges, but-in his own words -as "National Colleges for the advancement of general seientific and industrial education." In the fulfilment of this broad function, especially after the establishment of the auxiliary experiment stations, the colleges devoted themselves, from the start, to the promotion of agriculture and the dissemintion of constructive agricultural information. They were the first agencies in America to systematize crop rotation for soil building; first to restore worn-out soils by the use of nitrogen-gathering legumes; first to employ seed selection on a large scale for the improvement of plant varieties and crop yields; first to hybridize and top-graft selected fruit varieties with a view to the generil betterment of hortieulture; and first to demonstrate the value of scientific dairying and live-stock breding. They have taken the initiative in the destruction of insect pests, in the prevention, eradication, or abatement of crop and fruit diseases, and in the correction of the evils incident 


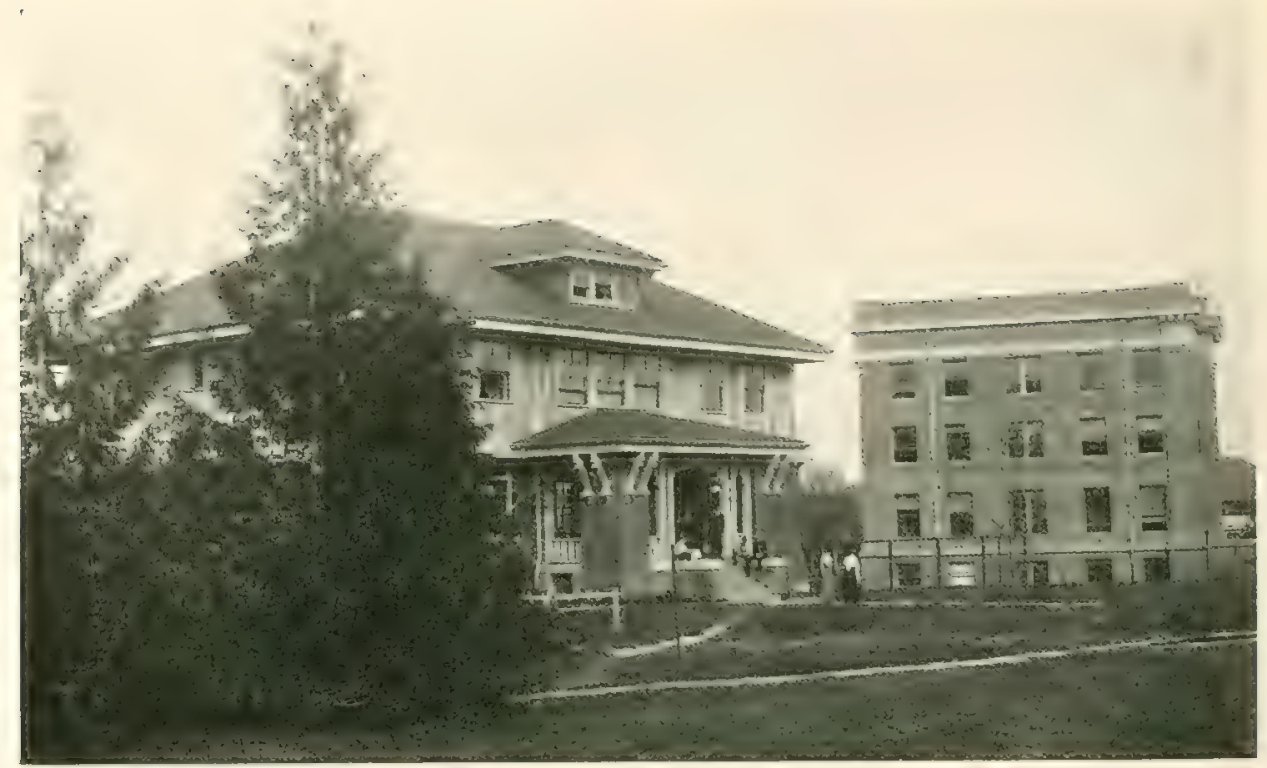

SHEPARD HALL, THE Y. M. C. A. BUILDING

to defective or excessive irrigation. They have led the way, through comprehensive campaigns of extension, demonstration, and farm cooperation, for the spread of constructive agriculture to every county and every community in their respectivestates. The agricultural colleges, in short, have been the most dynamic and immediate forces in the past half century in restoring old types of agriculture to a profitable basis; in opening up new and more reliable sources of farm production; and in mutually relating agriculture, on the one hand, and science and industry, on the other, in such a way as to broaden and energize the whole industrial situation.

In Wisconsin, for instance, to give a few generally-known examples in a state where statistics have heen regularly compiled, the development of an improved type of barley has yielded an income of $\$ 12,000,000$, and is still adding to this

Specific

Achievements.

sum; the prevention of wheat smut has saved the farmers from $\$ 2,000,000$ to $\$ 6,000,000$ a year, the development of a new variety of corn has added $15,000,000$ bushels of corn a year; and in the ten years from 1900 to 1910 the value of all farm property in the state increased over $74 \%$; the number of its cows increased $47 \%$; the annual value of its butter output $70 \%$; its cheese product $86 \%$; and its yield of corn from 25 bushels to the acre, the average for the whole country, to 36 bushels to the acre. In Illinois, improvement of corn culture, following practices advocated by the Agricultural College, increased the yield five bushels to the acre, resulting in an increased income of $\$ 2,000,000$ a year. The same sort of improvement of the corn crop conducted in Iowa by the Agricultural College, resulted in even more remarkable gains. In California, the destruction of orange scale saved the fruit 


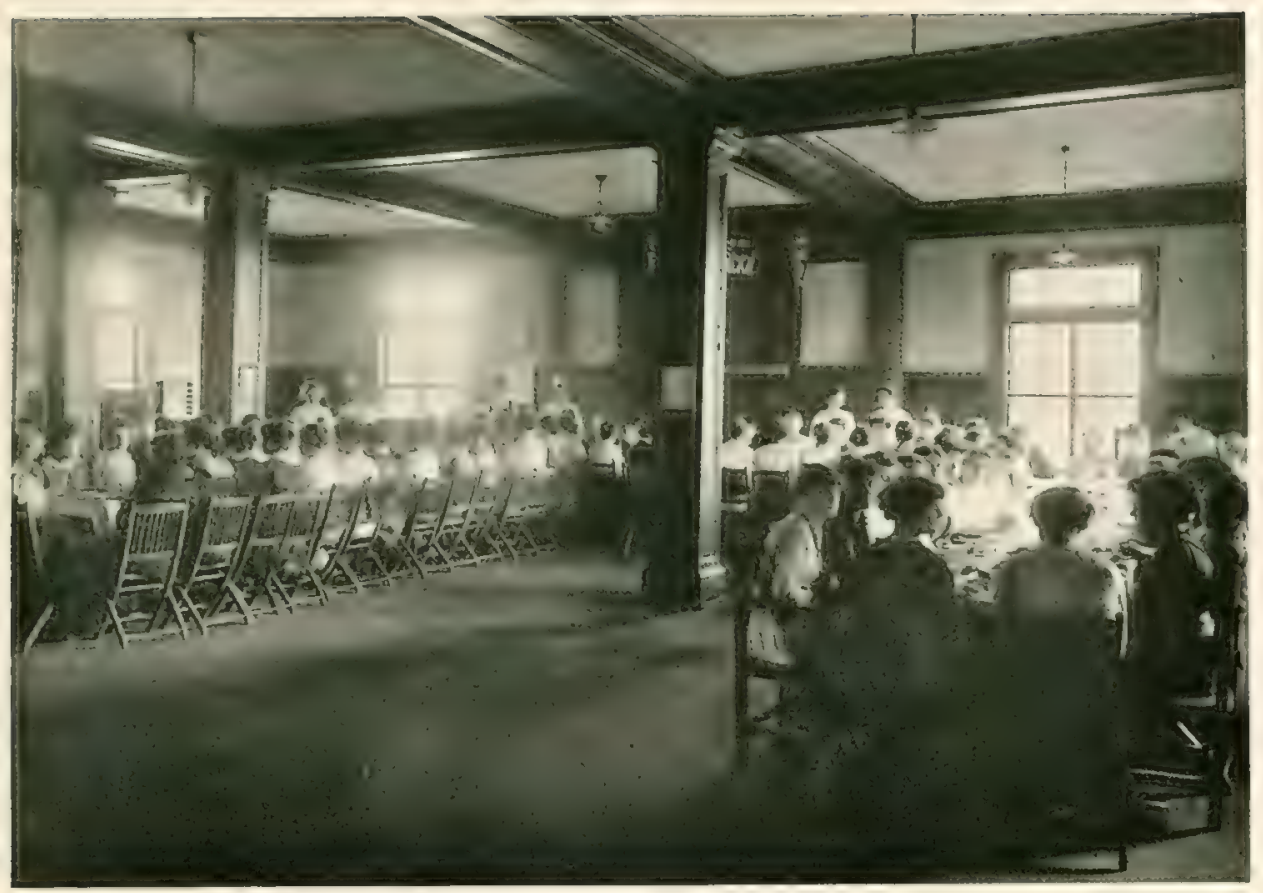

A Y, W. C. A, DINNER IN SHEPARD HATI,

growers $\$ 5,000,000$ a year. In Oregon, the benefits derived from the Station's demonstrations of improved moisture conservation for the dry-farming areas of the State, have alone been worth more than the total sum that the State has expended on the College.

Instances of the practical benefit of the experimental and research work of the College, often rumning into a money value of thousands of dollars, are multiplied in the pages of this bulletin dealing with the work of the different departUltimate ments. But these more or less immediate results of experiResults. mental effort are often the least of the services that the investigators, in library, laboratory, or field, are rendering to their institution and to the cause of science. Such results, while interesting and desirable, are often but the foam on the riffle of the stream, while the real gold of the washing is gathering in the hidden pocket for a future disclosure and use. It is truth that is essential, whether for today's application, or for use in the remote future. Benjamin Franklin expressed this well. To the critic who asked, concerning his kite and key experiment, "But of what use is it?" he replied, "Of what use is a new-born child?" 


\section{SCHOOL OF AGRICULTURE.}

\section{AGRONOMY.}

Over $40 \%$ of the agricultural products of Oregon fall under the classification of field crops-grains, hay, hops, root crops, and green forage. These yield a direct annual income of over fifty million dollars. Upon them depends an addi-

Leadership in Agronomy. tional income, through livestock, dairy, and poultry products of over sixty millions. ()bviously the ('ollege and Experiment Station have a large responsibility in fostering the vast interests involved in the growing of these products. The agronomy resources of the College, therefore- in traine experts, in laboratories, machinery, experimental and demonstration plats, branch stations, and cooperative farms-are proportionately important. The department since its organization hat been an aggressive and dynamic factor throughout the state in the introduction of new crops that have proved productive, new farm practices that have made for profit, and improved methods of seed selection, rop rotation, and farm management that have added both wealth and comfort to the agricultural population of the State. It has repeatedly taken the initiative in demonstrating to the people of the Willamette Valley that many crops, such as clover and corn, which were reputed to be impossible of reliable growth in this region, were not only safe but conspicuously profitable crops where selected, local-grown seed was used and suitable cultural methods were employed. In sixteen years the annual production of clover seed, in response to the initiative of the College, has grown from nothing to a crop valued at two millions.

In Crook and Sherman counties, by improved methods of tillage, the department has greatly increased the productivity of the soil. ()n land that would not grow alfalfa or field peas sown broudeast, he'ause of lack of moisture, it has demon-

In the DryLand Regions. strated that both crops can be grown in cultivated rows, with advantages over the wheat crop commonly grown. It has shown that rotations of fodder corn, field peas, or alfalfa sown in drilled rows, with wheat, will save summer fallowing once in three years. It has adapted ten varieties of choice small grains and five varieties of potatoes to successful culture on these lands, and has secured regular yields of forage corn as high as sixteen tons of silage to the acre.

When the branch experiment station of Eastern Oregon was established in 1911 at Burns, on sage-brush prairie where the annual rainfall averages but $11 \frac{1}{2}$ inches, our agronomists, by a series of borings through the surface soil, which was devoid of perceptible moisture to a depth of six to nine feet, found that 

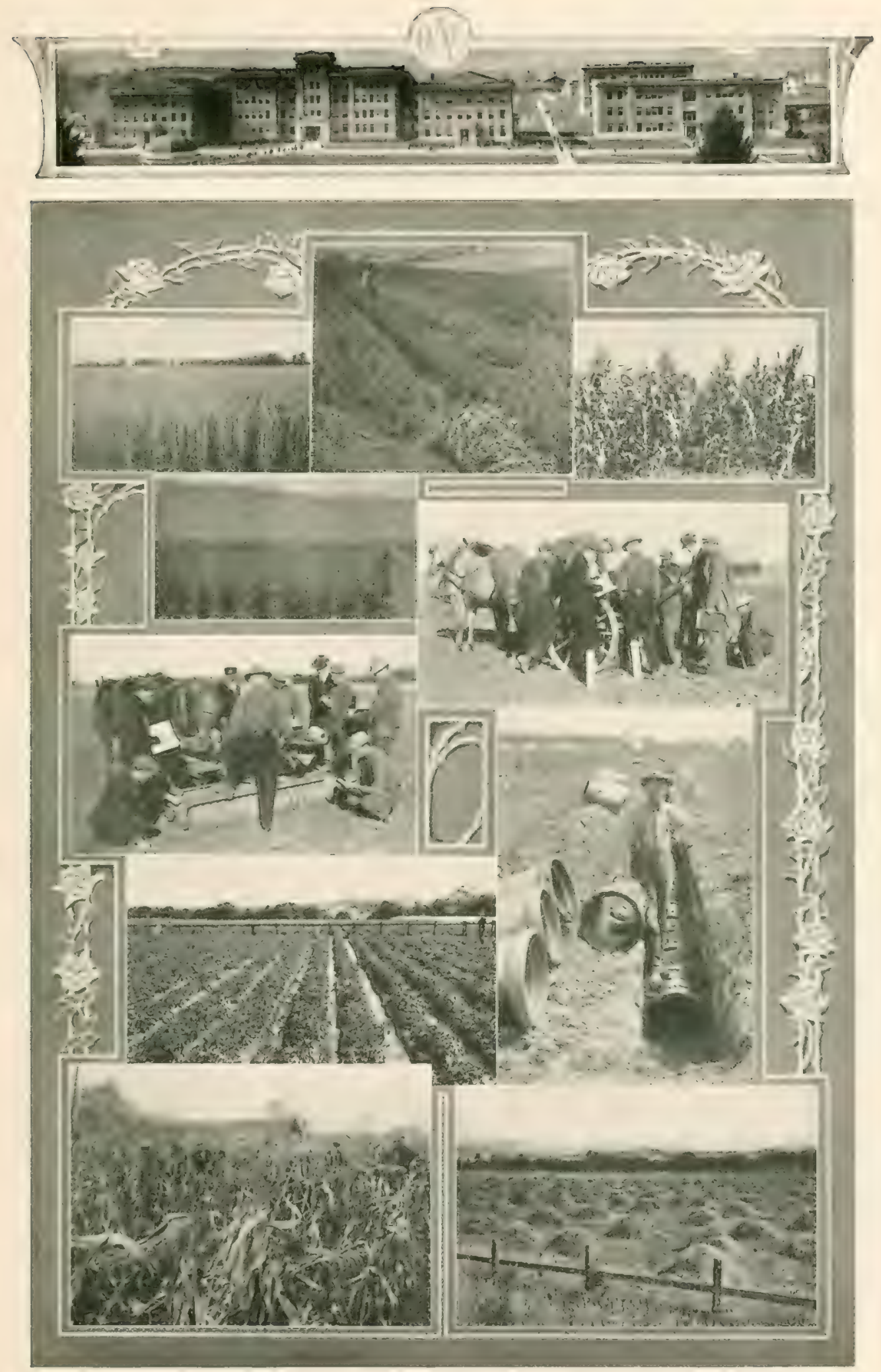
an underground flow of water lay at a depth of ten to twenty feet below the surface. They promptly undertook the task of driving down the surface

In Moisture

Conservation. moisture, conserved by careful tillage, to meet this underground water table, which would thus become available, through capillary movement of moisture, for the nourishment of field crops. Within two years from the time this method was put into practice, 80 per cent of the two-hundrea acre tract so treated had responded adequately to the treatment; the surface moisture had joined the underground moisture, and the crops were noticeably improved. This discovery gives promise of remarkable athievements. Since vast tracts of tillable sage-brush land in Central Oregon are undoubtedly underlaid with an accessible water table like that on the station farm, similar methods of tillage promise to bring about similar results, transforming, throughout a wide area, a strictly dry-farm practice into what may safely be termed a sub-irrigated system of cropping.*

The Oregon Agricultural College was among the first in the country to offer agricultural class instruction in Irrigation Farming. The laboratory for this work is the irrigated field on the College Farm, where the students learn to

\section{In Irrigation} Farming. build wiers, measure water, lay out aistribution systems, make cement pipe for laterals, and test pumping machinery. Experiments in irrigation methods for Willamette Valley conditions were begun at the College in 1907 . They have since been regularly maintained and extended until they now number sixty plats and comprise nine different crops of standard varieties. Seven years' data covering these crops show a profit from irrigation with all but one of them.

Results of the experiments may be readily indicated by giving a few specific instances. Corn has given an average profit of forty-three cents for each acre inch of water applied; kale, sixty cents; alfalfa, one dollar and sixty-five cents; clover, two dollars and seventy-one cents; carrots, six dollars and eighty-three cents; and potatoes, seven dollars and seventy-five cents. The average increase in yield by crops, in short, has been fifty-three per cent. The experiments have thus shown conclusively that irrigation may be successfully practiced on the welldrained silt loam and sandy loam soils of Western Oregon in connection with intensive dairying, hop growing, and truck gardening. $\dagger$

The College has been a consistent advocate of drainage for the heavy soils of the Willamette Valley and similar sections of the State, especially for the socalled "white lands." It has demonstrated that the proper tiling of fields is both an immediate and cumulative benefit to crops, allowing the working of the land at a more seasonable time, giving greater aeration to the soil, promoting sub-irrigation, and ultimately bringing about beneficial changes in the character of the soil.

*Station Bulletin 119. TStation Bulletin 122 

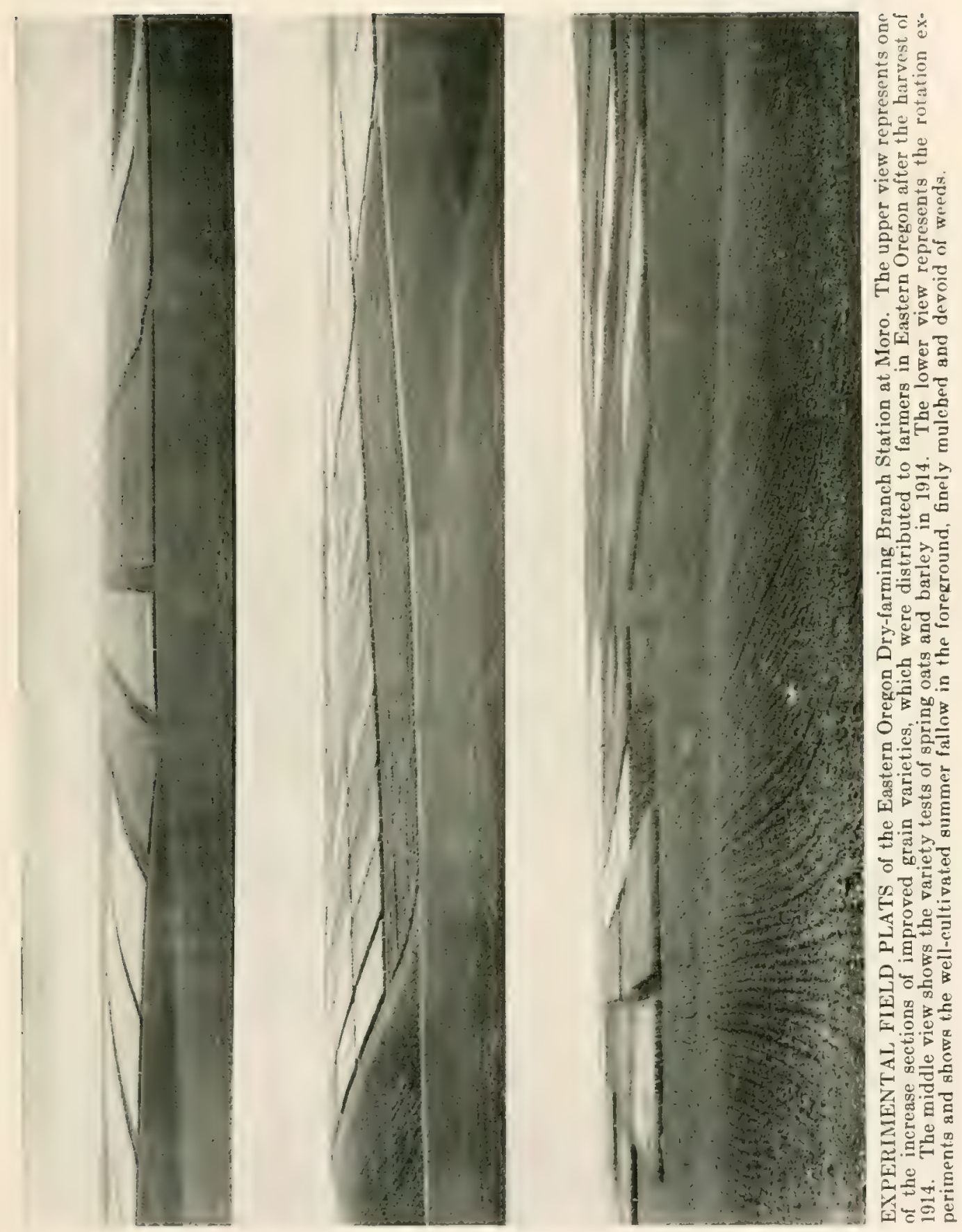
As a result of initiative steps taken by the College, drainage operations in the Willamette Valley have been exceptionally dynamic this spring. The United States Government, cooperating with the College, has assigned to this field a

In Drainage Operations. specialist from the Drainage Division of the Department of Agriculture. Following the Drainage Conference held at the College during Farmer's Week, moreover, a suitable district drainage proposal was submitted to the state legislature. This having become a law, petitions for the organization of drainage districts under its provisions have ben rapidly put into effect. As a consequence, drainage operations in the Valley promise to be much more extensive, as well as much more thorough and scientific, than ever before.*

Experiments in plant breeding, seed selection, crop improvement and prevention of disedses ates a few additional problems that have occupied the attention of the sturlent and faculty investigators in the department. Many of the students

In Miscellaneous Problems. in crop improvement have been given opportunity to do a certain amount of field selection of various plants in an attempt to develop the best types. An instance of the results of this method of experimenting, is the selection of a type of kale plant that shall have the largest amount of succulent and palatable foliage. Such a type of kale plant has been developed at the College, the seed of which is now in great demand. Another interesting problem in which the investigation of a Senior student taking s] ucial work in crops brought about positive results of value, was that of the honeydew of clover, a pest that has become a serious menace to this crop. The investigation showed that clover seed may be suecessfully freed from honeydew without injury to its power of germination, if the seed is soaked for ten minutes in water at $96^{\circ}$ Fahrenheit and then promptly removed and dried.

Numerous other problems in this department that are enlisting the absorbed attention of bright young men and women are such as the germination of the hard seed of legumes, the effects of certain treatments for smut of cereals, the temperature at which seed corn can be most safely and rapidly dried, and field selection of certain types of potatoes and other plants. These are but instances of the simpler and more practical problems that engage the attention of students and teachers in a single department of the College. They suggest the challenge as well as the ample range, of the questions that cry for solution in the march toward agricultural efficiency. They call for brains and insight, as well as for patience and industry, and they involve the most implicit respect for the processes of nature.

-A Station Bulletin concerning this work is being prepared for publication. 


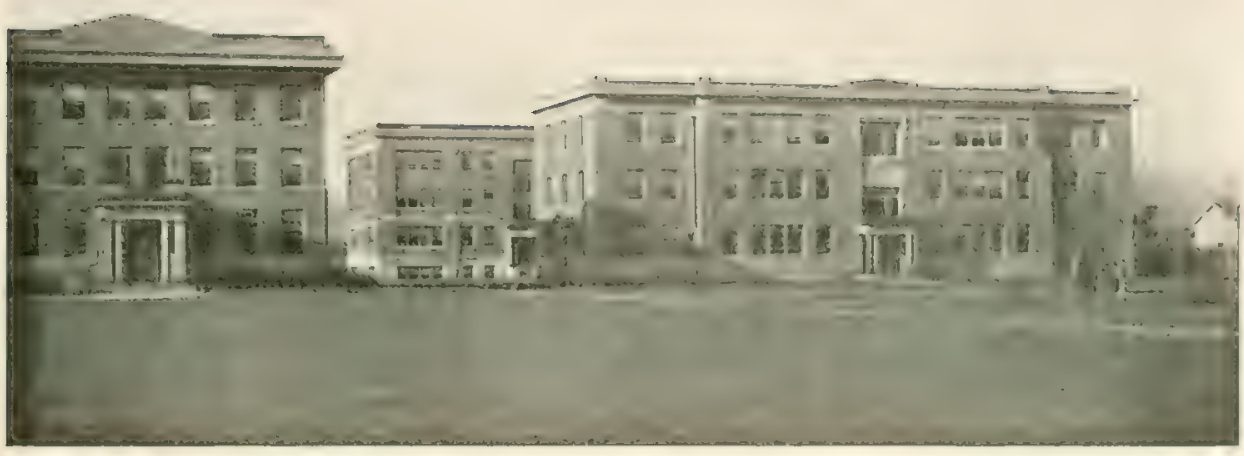

THHEE CORNERS. AGRONOMY. DAIRY AND HOME ECONOMICS BUILUINGS

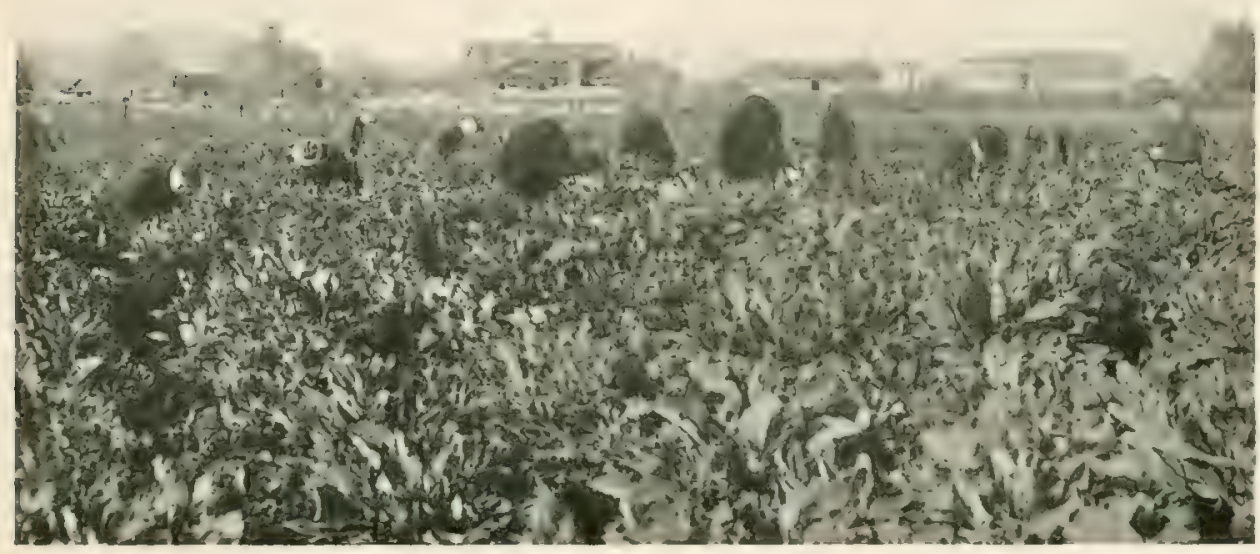

FIELD SELECTION OF KALE PLANTS FOR THE RAISING OF CHOICE SEED

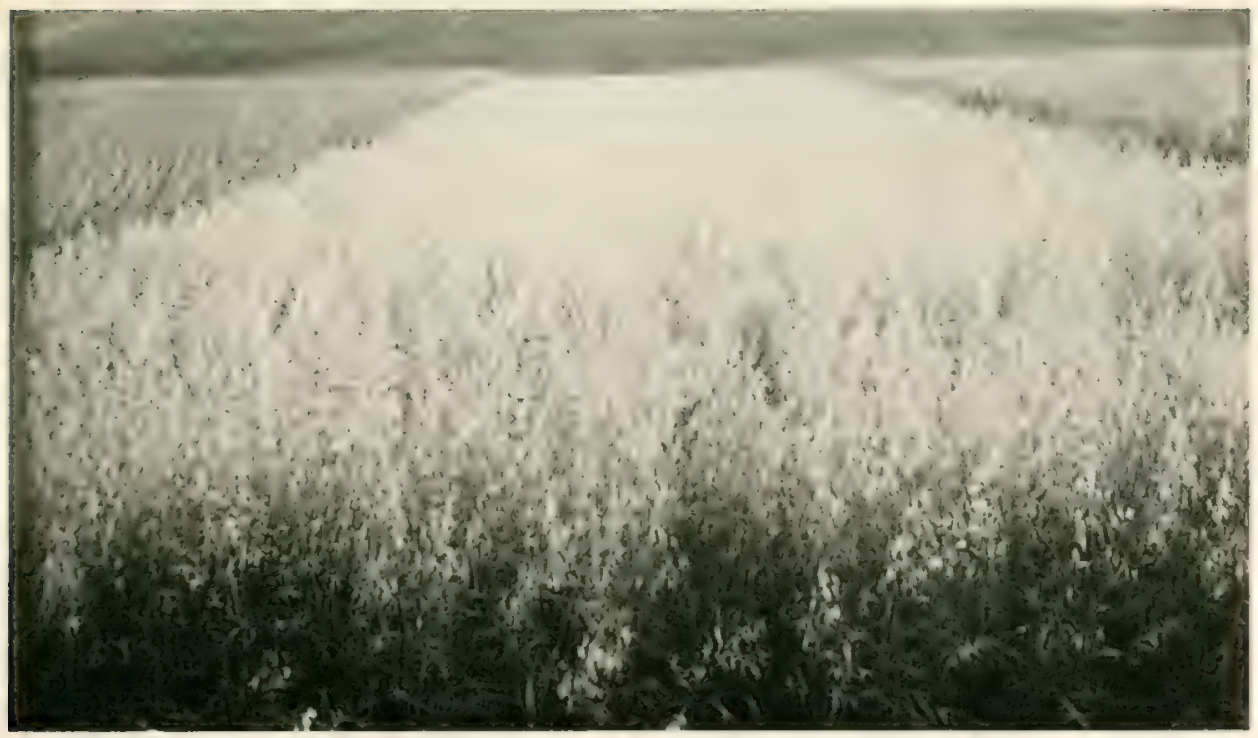

A SELECTION FROM THE SIXTY-DAY OAT THAT YIELDED 67 BUSHELS TO THE ACRE, ON DRT-FARMING LAND, IN 1914. A COLLEGE PRODUCT AT THE MORO BRANCH STATION 


\section{ANIMAL HUSBANDRY.}

The Animal Husbandry department has made notable progress during the past few years in initiating and solving many problems of paramount importance to stock raisers in Oregon. Its work in growing and marketing meat animals

Experiments in Fattening Live Stock. to the greatest economic advantage, has met with pronounced success, both its beef cattle and its lambs topping the Portland market for the year and netting handsome profits. Experi-

ments at the Lastern Oregon (Moro) branch experiment station, in fattening steers for market, demonstrate the value of various grain rations when fed in connection with alfalfa hay, as compared with an exclusive ration of hay. Experiments in fattening hogs have demonstrated also, beyond question, that the common practice of finishing hogs on grain alone is not an economical practice. Some supplementary feed, notably clover or alfalfa pasture or hay, is essential to rapid and profitable gains. Digester tankage has proved profitable, but the most surprising gains were made on alfalfa pasture as a supplement to a full grain ration, hogs finished in this manner netting a profit of $\$ 222$ a carload over hogs finished on grain alone. ()ther experiments in hog feeding at this branch station have shown conclusively that field peas, fed green-when at the right stage for cooking-produce a remarkably quick-maturing and high quality of pork. Forage corn, experimented with it this station and at others of the branch stations and demonstration farms, his also proved a very profitable method of finishing hogs in the field. Fixperiments in the use of the self-feeder, especially when employed in connection with alfalfir or clover pasture, have demonstrated the efficiency of this device as compared with the usual method of hand-feeding for finishing hogs.

Other investigations with swine have involved studies extending over a number of years concerning inherited traits of fecundity, rapid maturity, economical fattening, and similar characteristics. Results of these inquiries will soon be

Studies with Swine. ready for publication. These and numerous other investigations, not mentioned here, have been giving an emphatic impetus to the industry of growing hogs in Oregon, whether in the humid sections of the Willamette Valley and Coast Region or in the irrigated and semi-arid sections of Central and Eastern Oregon. The general freedom from diseases, particularly hog cholera, throughout the State, and the ease with which forage crops, such as clover, alfalfa, field-peas, and corn can be grown, make this industry a convenient, safe, and profitable feature of all types of general farming, and particularly of dairying.

For years the College has been rearing some fine specimens of Cotswold and Shropshire sheep, and has been a leading factor in the movement that has given 



ANIMAL HUSBANDRY

SPECIMENS OF THE COLLEGE LIVE STOCK. NEW STOCK BARN AT FOOT OF THE GROUP' 


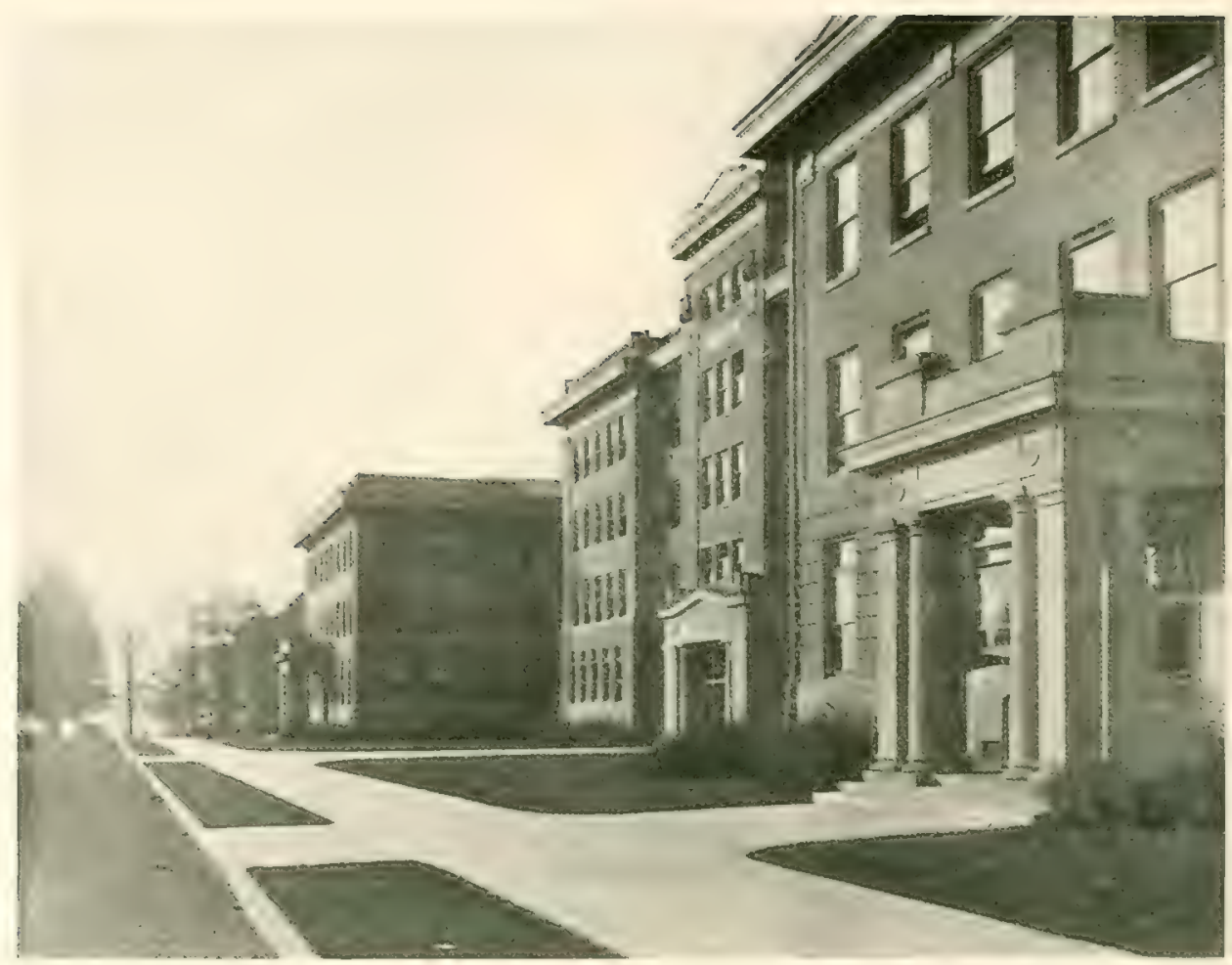

FRONT OF AGRICULTURAL HALL LOOKING SOUTH TOWARD WALDO HALL

Oregon an enviable reputation as the home of well-bred and high-producing

Building the

Sheep Industry.

sheep. The possibilities of wool production in Oregon, as well as the growing of lambs for a choice market, are as ample as the rich and varied grazing resources of the State, and as

favorable as its mild and equable climate.

The College has been a pioneer in its advocacy of pure-bred horses in Oregon; and in recent years has led a most vigorous and effective campaign for the standardization of breeding practices in the state, including the elimination of mongrel

\section{Striving for} Better Horses. sires. This work has already brought positive results, and has atwakened such general and favorable support that the success of horse breeding in Oregon seems to be assured.

With climate and crop conditions, throughout almost the entire agricultural portions of the State, as favorable for horse raising as in England or Belgium, it would seem that this dectivive step in the direstion of better breeding should place the State in an ascendant position in respect to raising fine horses. With the enlarged and insistent demand that is arising as a result of the European war, moreover, and that seems likely to increase the moment peace is concluded, because of Europe's imminent need of work horses, this campaign will doubtless anticipate, within the next decade, a very liberal harvest for Oregon horse breeders. 


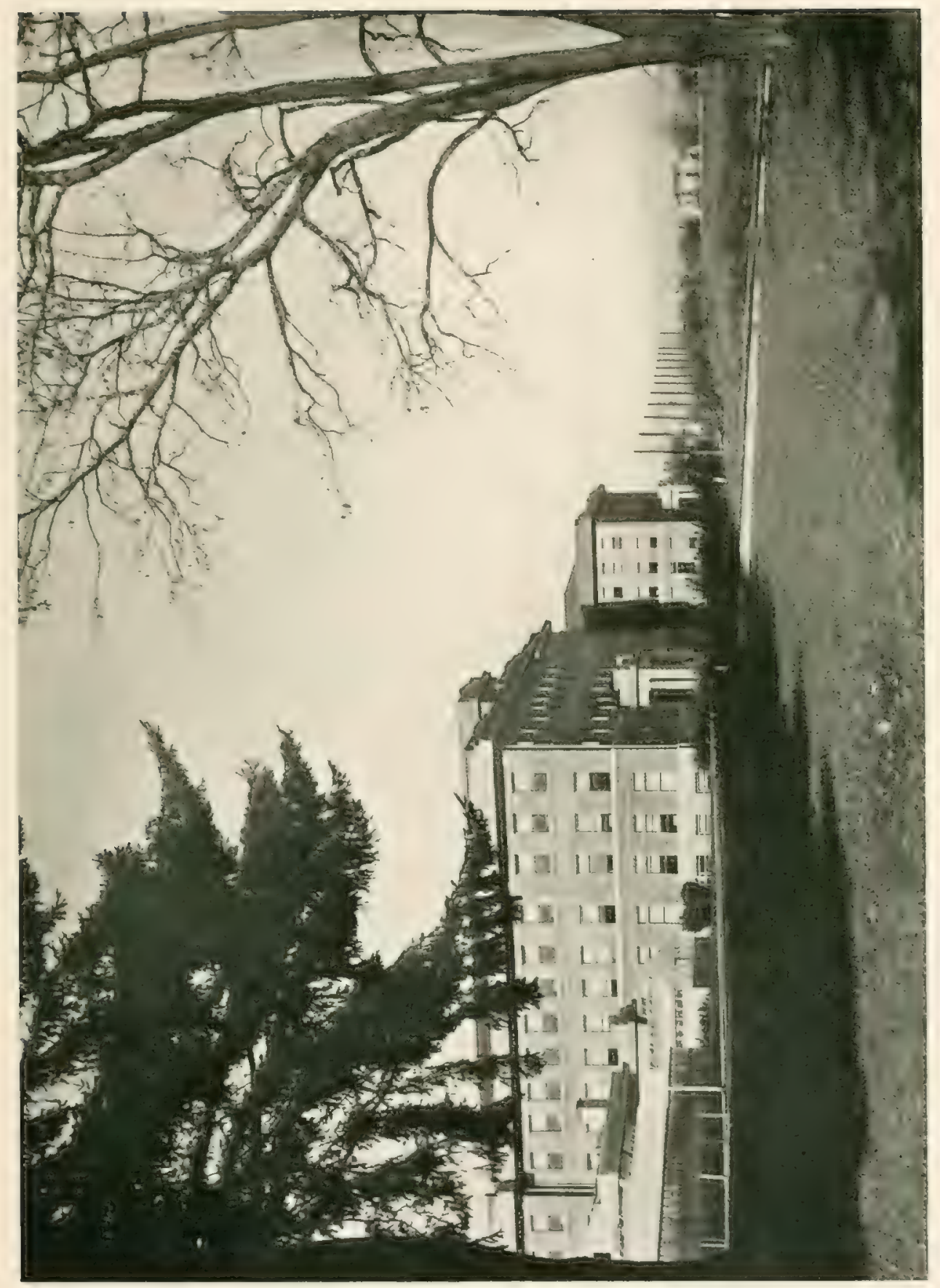

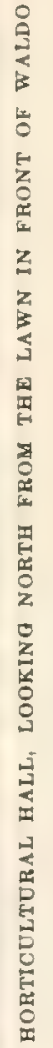




\section{DAIRY IIUSBANDRY.}

Dairying in Oregon is an industry as varied as the chief geographical regions of the State. Each of the grand divisions of the commonwealth has climatic conditions and consequently crop conditions, peculiar to itself. Its dairying is

Various Dairy Problems. peculiar, too. Tillamook, and other humid coast valleys, the hills of the coast range with their narrow mountain basins and gorges, the valleys of Southern Oregon, and the great Willamette valley, all have their cheese factories, their creameries, their condenseries or their local markets, and carry on a distinctive dairy industry. Aside from these principal dairy regions, there are certain localities here and there throughout the State-in the Blue Mountains, in Northeastern Oregon, in Crook and Klamath counties - where the dairy cow is contributing a generous share to the annual income of the farm.

It is evident that so varied an industry, conducted under diverse conditions of climate, altitude, feed resources, and market facilities, involves correspondingly varied problems. These problems, the College has been vigorously assailing. In order to understand them to better advantage, a systematic

Efficiency Campaign. survey of the dairy resources of the State was recently made by the College specialists through various agencies. This revealed the fact that Oregon, in spite of her exceptional natural advantages, is in need of just such a campaign for dairy-herd improvement as has been carried on in Ohio, Wisconsin, and many other states. From the 174,000 cows used exclusively for dairy purposes in Oregon, it appears that the average production of butterfat is less than 200 pounds for each cow. Of the 18,500 herds of dairy cattle, only 1,200, or approximately seven per cent, are headed by pure-bred sires. This low average production, in the face of highly satisfactory returns where dairy practices are efficient, is found to be due to one or more of several causes; namely, the failure to eliminate from the herd the low-producing cows; the failure to obey proper feeding principles with some or all of the cows; the failure to produce the right kinds of crops to the full capacity of the available land; and the failure to provide buildings properly arranged and constructed.

To improve these conditions, the College Dairy department, through the Extension Service, in cooperation with the United States Department of Agriculture, through the Dairy division, has been conducting a state-wide campaign for approximately two years. Results of these activities have

Brings Prompt Results. been prompt and encouraging. During a single year under the supervision, direct or indirect, of the College representa-

tives, twenty-nine silos, including six solid-wall concrete structures, with a total capacity of 1,926 tons, have been built throughout the state, at an average cost for each ton eapacity of $\$ 2.56$. This is but the beginning of a movement, coupled 

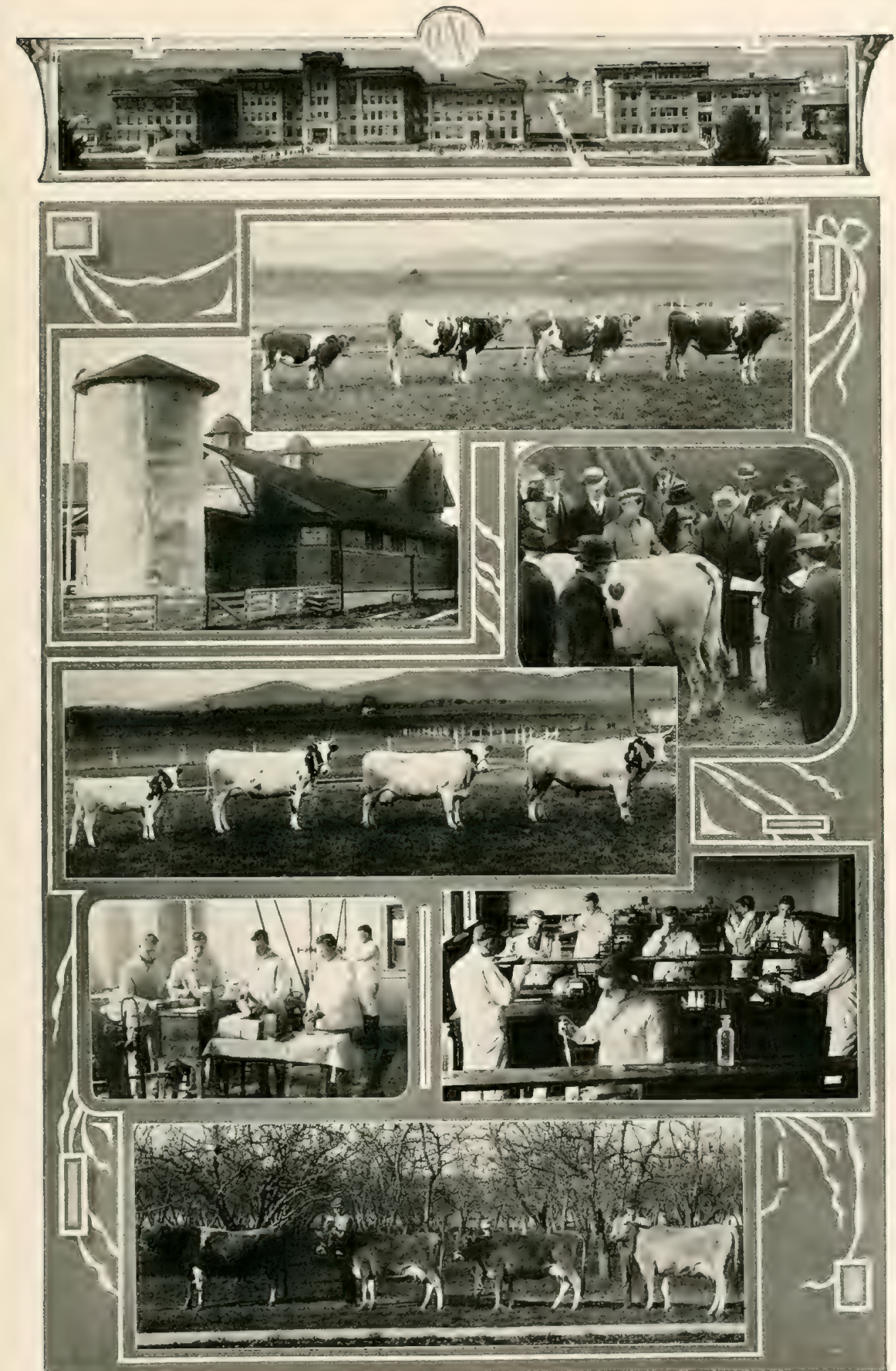

DAIRY HUSBANDRY

SPECIMENS OF THE GLERNSEY, AYRSHIRE AND JERSEY GROUPS, COLLEGE DAIRY HERD, WITH

GLIMPSES OF THE NEW CONCRETE SILO, STOCK JUDGING, BUTTER MOLDING, AND MILK TESTING 
with that for the more general production of corn, that promises to give a new and telling impetus to profitable dairying in Oregon.

In connection with this pioneering service on the part of the College dairymen, assistance has also been rendered to farmers in the building of four modern dairy barns of the two-story, gambrel-roof type and four modern milk houses.

In Better

Equipment. to farmers who contemplate building barns, silos, or milk-houses, blue print plans, bills of material, and suggestions for guarding against mistakes commonly made in erecting dairy buildings. Whenever possible, a representative of the College will respond to requests to visit the farms of the builders and give personal supervision in beginning construction. These services are given without cost to the farmers, in behalf of better dairy practices for Oregon, which must result ultimately in better health and greater prosperity for all her citizens.

Dairy herd record keeping, another extension activity of the Dairy department, is still in its infaney in Oregon; but it is making a lusty growth, nevertheless, and promises great things for more general economy in the conduct of the In Dairy Records. dairy business. During the past year, under the direction of one of the College representatives, four dairymen, in different parts of the State, have been keeping systematic records of the daily feed and the daily milk-yield of their cows. Results have been striking, and the savings involved have compensated many times for the pains involved in the work. In one instance, the saving due to a change of ration from certain high-priced protein feeds to equally efficient substitutes, amounted to $\$ 30$ for the herd during the first month following the change. But results are by no means confined to the individual dairymen who keep records of their herds. These men, often recognized as the most progressive in their respective communities, become examples of genuine, open-eyed prosperity in the dairy business, in contrast to an indifferent, hap-hazard method which shuts its eyes to plain facts, and blindly suffers from year to year those leaks that in the end drain the farm of profits and sap rural life of its joys.

Still another phase of the pioneering movement for a more thorough, sanitary, and permanently profitable dairy industry in Oregon is the institution in the public schools of the Dairy Record Contests, in connection with the Boys and In Public School Cooperation. Girls Industrial Clubs. Forty public schools in the Willamette Valley have installed Babcock testers for the use of the pupils in carrying on their daily records of the herds at home. Regulation forms for keeping the reeords are supplied by the College Extension service, and representatives of the Dairy department visit the schools as frequently as possible to supervise and assist the work. Enthusiasm for this undertaking is 

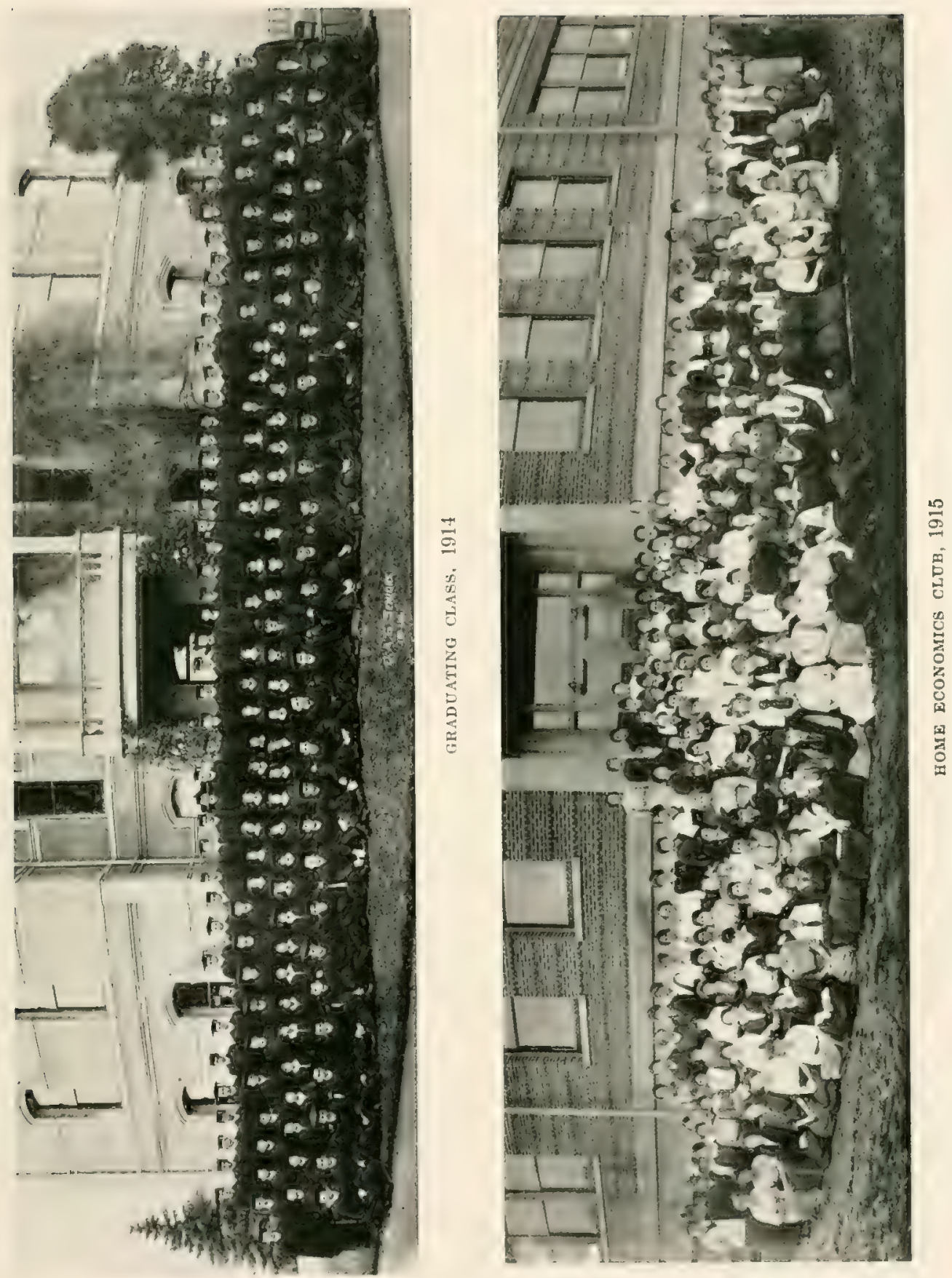
general and sustained. It not only brings positive and beneficial results to the dairies that are concerned, it brings closer together the home and the school, and opens up new channels for the diffusion of progressive intelligence and cooperative ideas for community development. Best of all, it interests the school children, through the regular school work, in the economic problems of the farm, instills habits of searching and thorough work, and excites a just and intelligent pride in the occupation that most of them will ultimately pursue. It imbues them, in short, with the alert, inquiring spirit of the trail blazer; and gives assurance that from each of these school communities will ultimately go forth certain young people who will not only have the initiative to cut new paths, straight and clean, into the unknown or the unused fields of agriculture, but will have both the habit, and the disposition, to uphold the pine-knot of community effort.

\section{VETERINARY MEDICINE.}

Veterinary Medicine, a comparatively new department at the College, has already shown by its services to the institution and the State, that the hour was ripe for the establishment of this work. The public realizes today, as never before, that the ultimate elimination in human beings of such

Prestige of Veterinarian. diseases as tuberculosis, is dependent upon the control of these diseases in animals that furnish food for man, hence the skilled veterinarian has taken rank with the physician. The increased value of live stock, particularly registered animals, which amounts in many instances to twice that of a dozen years ago, has also made insistent the calls for a competent veterinary surgeon. The larger prevalence of contagious diseases, moreover, due to the increased transportation of live stock, together with the efficiency of the government and state campaigns for the elimination of these diseases, through the medium of the licensed practitioner, has enlarged the field and the importance of the veterinarian.

At the Oregon Agricultural College, instruction in veterinary medicine is offered primarily for the sake of giving necesary information to students in animal and dairy hushandry and in general adgriculture, rather than to fit them for the profesional duties of a veterinary, though the courses, taken in conjunction with those in agriculture, make an admirathe preparation for the strictly professional work.

While the duties of class instruction, clinical demonstrations, and extension appointments, consume most of the Veterinarian's time at the College, he has nevertheless done considerable work in investigating local diseases of live stock

Veterinary

Work at O. A. C. and has given particular attention to the general problem of sterility in cattle. Through conferences with cattle men, farmers, and others interested in upbuilding the live-stock industry, moreover, he has exerted a constructive personal influence toward conserving the health and integrity of the live-stock herds of Oregon. 


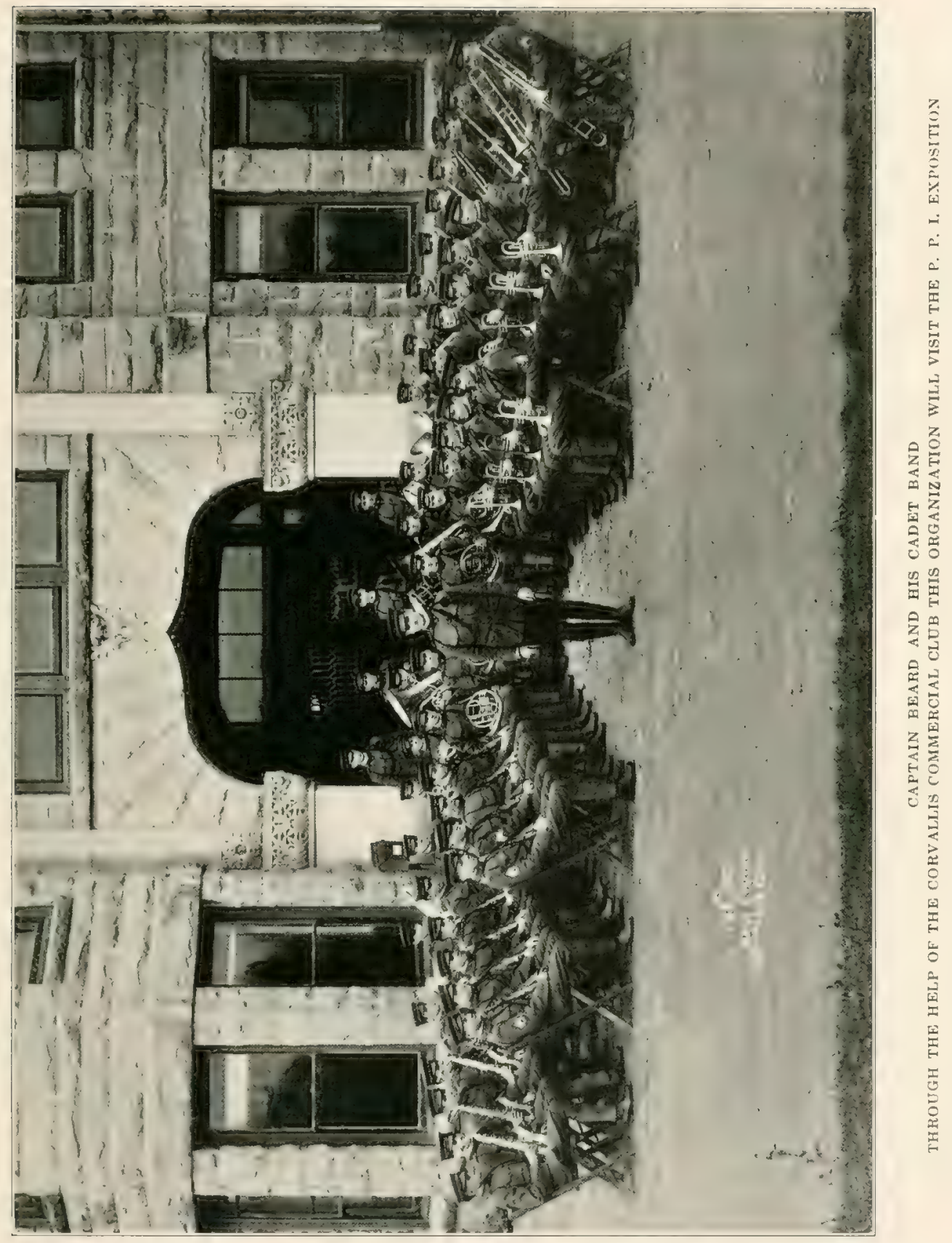




\section{HORTIGULTURE.}

The Division of Horticulture has been developed to proportions commensurate with the importance of the horticultural resources of the State. An industry, the combined products of which amount to the grand total of ten million

Leadership in Horticulture. dollars annually, naturally involves many important and complex problems, requires the services of many experts to safeguard and guide its progress, and demands instruction for hundreds of youths from various parts of the State. 'These functions the division is adequately prepared to perform. The division comprises several types of work, such as Pomology, Tegetable Ciardening, Iandseape Gardening and Floriculture, besides Special Research, and includes also the branch experiment stations at Umatilla, Southern Oregon, and Hood River. It carries on, in addition, a regular program of horticultural extension.

While only one section of the Division of Horticulture is primarily devoted to research and investigation, pursuing, in many instances, highly technical problems that are fundamental to the tasks that the division is striving to work out, all its resources are really enlisted in the work of investigation, in bringing toward solution the horticultural problems of the State. At different times the Division has had under investigation problems that have yielded such results as are briefly summarized in the following statements.

Frost fighting and orchard irrigation investigations in the Rogue River Valley, conducted between the years 1907 and 1912, led to definite conclusions of positive value to the fruit growers of Southern Oregon. 'These conclusions were summarized in two Station publications.*

The Pollenation Problem, which has now been under investigation by the horticultural experts of the College for over eight years, and has yielded significant results, is still in progress. Several publications, issued from time to time, have

The Pollenation Problem. summarized the results of their researches, so far as facts were determined in the particular instances. $\dagger$ The essential points of practical value to the general fruit grower, may be briefly suggested in a few statements. All varieties of pome fruits, especially apples and pears, even though the varieties are termed self-fertile, are benefitted by having other varieties planted with them as pollenizers. One variety as a pollenizer for another will serve as well as twenty varieties; hence promiscuous variation is unnecessary for pollenation and inconvenient for practical orcharding. The kind of pollen used has nothing to do with the color, flavor, or quality of the fruit; for pollenation affects chiefly only three important factors; namely, 

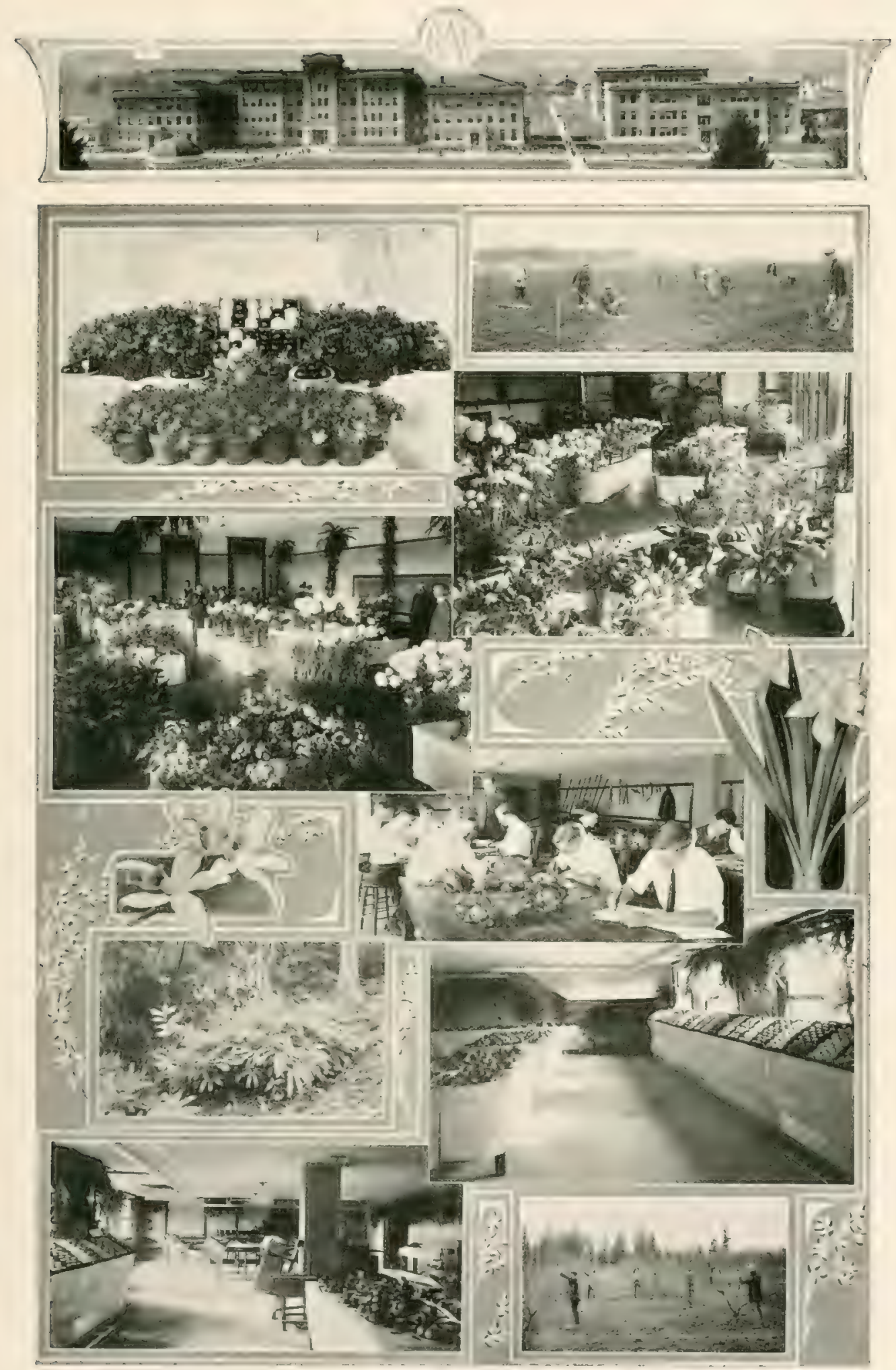

HORTICULTURE

SHOWING VARIOUS VIEWS OF THE 1914 "HORT. SHOW" AT THE COLLEGE, WITH TREF PLANTING, LARORATORY PRACTICE IN VEGFTABL GARDENING. AND ORCHARD PRUNING: 
size of fruit, percentage of set, and uniformity. Precautions to be observed in planting different varieties for pollenation purposes, are that the varieties must bloom at the same time, must have an affinity for one another, must be good pollen producers, and must be commercial varieties.

Concerning the pollenation of the sweet cherry, careful investigations have brought out the following facts, which are of the utmost importance to all cherry growers in the Pacific Northwest. All varieties of the commercial sweet cherry

\section{Pollenation of} Sweet Cherries. are self-sterile, and certain of these varieties most commonly cultivated for the market; namely, Bing, Lambert, and Royal Ann, are inter-sterile. It follows that these varieties of cherries must necessarily be pollenated by other varieties, among which the most successful pollenizers proved to be Black Republican, Black Tartarian, and Waterhouse, together with a number of seedlings. The latter, however, cannot be relied upon as safe pollenizers unless subjected to individual tests.

Investigations in strawberry, cherry, prune, and apple breeding, which are closely allied to the pollenation investigations, have been under way for several years, the object being to develop superior types of these fruits. Extensive

\section{Breeding and Selection.} experiments with two hundred varieties of strawberries, conducted during the past six years with the aim of determining the best variety of strawberry for various purposes in Oregon, have shown that very few of the popular varieties of this fruit can measure up to the existing standard that a great fruit-growing state like Oregon demands. Only six varieties are considered worthy of direct approval for specific purposes.*

Researches and investigations in the handling of the fruit crops and in utilizing fruit and vegetable by-products** have been 'mbodied in popular bulletins, as have also the preliminary results of special investigations with loganberry byproducts. $\dagger$ From the latter investigations it appears that one of the most attractive uses of the loganberry is for juice, which, as a beverage, has superiorities over the more popular grape juice.

Other researches of the Horticultural experts, results of which are not yet concluded, concern the culture of walnuts, the control of fruit-pit of apple, and the subject of orchard economics. The latter study, a searching and comprehensive survey, will be of the utmost importance to the practice of horticulture. ${ }^{1}$

Horticultural experiments at the branch stations, though these were established only in recent years, are already proving valuable. At the Umatilla branch station, five-years investigations with wind-breaks and hedges designed to protect

The Branch

Stations

Contribute. growing crops and farm houses from the evils of drifting sand and hot summer winds, have resulted in definite recommendations embodied in bulletin form. $\neq$ From the same branch station also, as a result of experiments covering five years of successful

-Crop Pest Report 1913-14. 1Station Bulletin 132

sCollege Bulletin 118. "College Bulletin 128. TStation Bulletin 117

tStation Bulletin 125. 

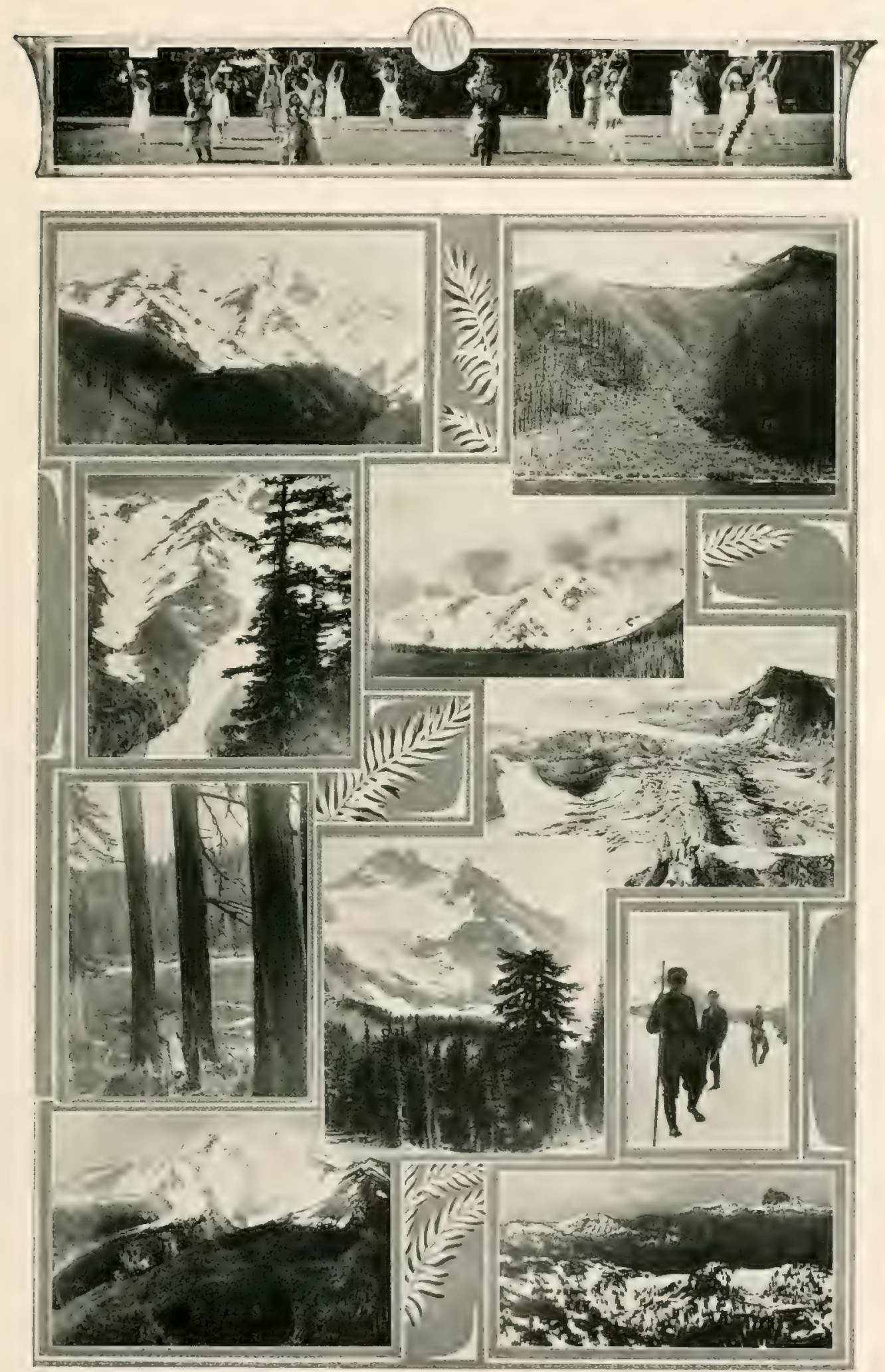

VIEWS OF MT. JEFFERSON, KING OF CENTRAL CASCADES, A DAY'S JOURNEY FROM THE COLLEGE 
culture, have recently been issued recommendations concerning the growing of grapes under irrigation, with particular reference to commercial production, in the light soils of Northeastern Oregon.* Other investigations of the Umatilla branch experiment station that promise to lead the way to new farm practices of permanent importance to northeastern Oregon are those concerning the use of green manure crops in improving sandy soils, ${ }^{* *}$ variety tests of cane fruits and of strawberries, irrigation experiments with apple trees and other crops, and several soil-building experiments.

The horticultural work of the Southern Oregon branch experiment station, located at Talent in Jackson county, has led to the discovery of means whereby all the advantages of commercial fertilizers for the growing of alfalfa as a cover crop or for hay, may be secured at a saving of $75 \%$ of the cost of such fertilizers. $\uparrow$ For the control of pear blight, the worst enemy of the pear industry in Southern Oregon, the station is making the most searching and sustained efforts, chiefly toward discovering varieties and stocks resistant to the disease. To this end, four hundred varieties of pears are being tried out, and indications already point to four varieties which are blight resistant. These are being propagated as rapidly as possible, and if they prove resistant to blight, they will be offered for general cultivation. To this end, also, root stocks have been collected from all parts of the world, and as they show resistance to blight are being top-grafted with commercial varieties, to determine whether the bodies of these trees will also remain free from blight. Success in these experiments will mean the safeguarding and perhaps the doubling of the pear industry of Oregon, which represents, in the southern counties alone, an investment of ten million dollars. The ultimate importance of this pioneering work is almost beyond estimate.

Additional investigations conducted on a large scale at this branch station have as their goal the production of a strain of pears, prunes, and other fruits devoid of the particular defects that now impair the absolute excellence of some of our choice commercial fruits, and possessing the distinctive qualities for which these varieties are already famous. $\dagger$

Investigations at the Hood River branch experiment station, which were begum only in 1913, have not yet been in progress long enough to warrant definite conclusions; but results of one-year experiments with orchard fertilizers, shade crops, root systems, etc., give promise of some very interesting recommendations when the investigations are completed. $\ddagger$

- Etation Bulletin 126.

* Station Bulletin 120.

tReport of the Southern Oregon Branch Experiment Station, 1915

+ Report of the Hood River Branch Experiment Station, 1915. 


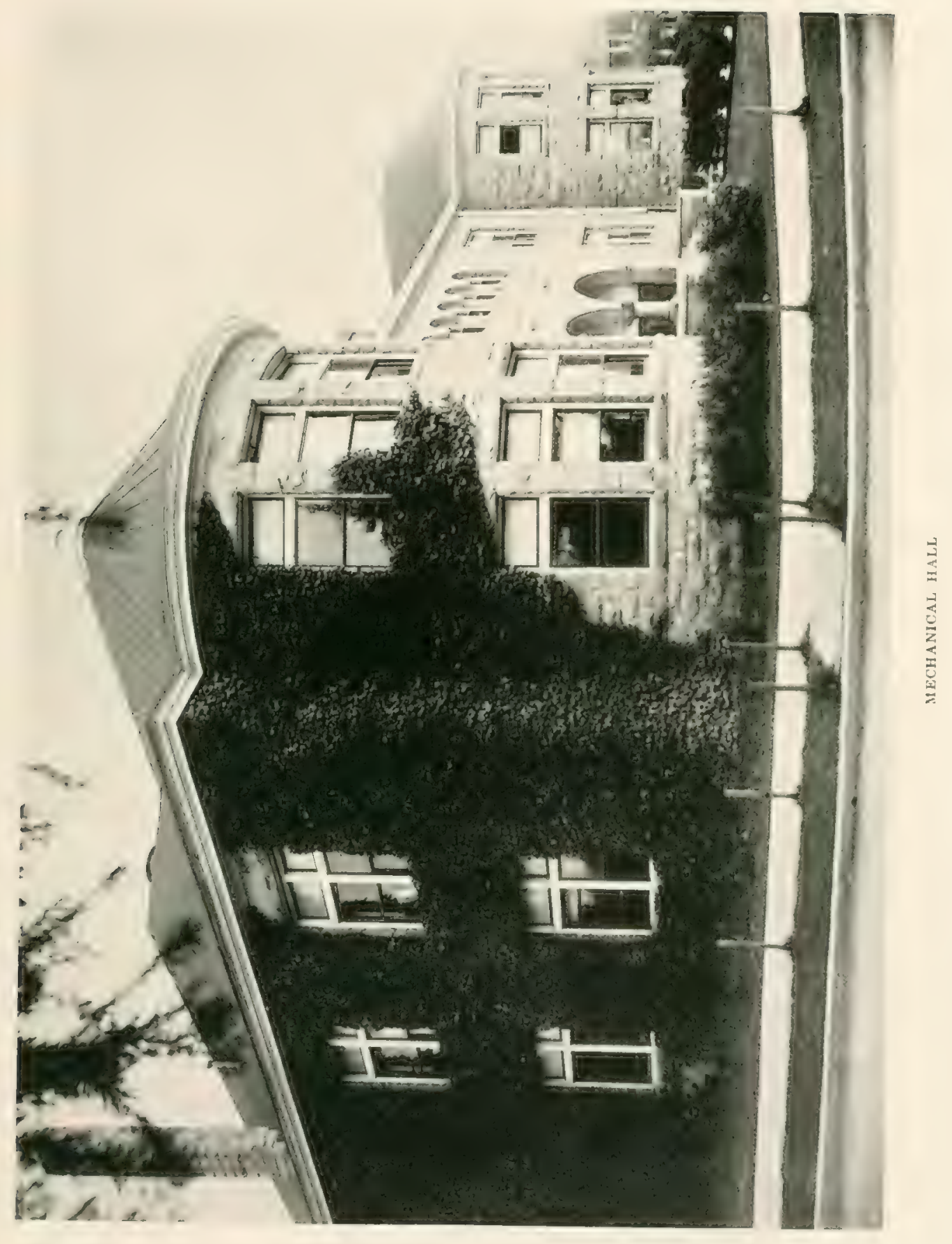




\section{POULTRY HUSBANDRY.}

The department of Poultry Husbandry, in the course of several years of investigative work, has broken quite a number of idols piously upheld by the fanciers of the domestic fowl. As a result, a new standard has been erected in the lists

New Standard in Poultry World. of the poultry world-the standard of production, rather than plumage; efficiency, rathar than fine points. Not how stylish you look, but how well you lay, is the new note of approval in addressing biddy Barred Rock or biddy Brown Leghom. Not how impeccably perfect your top-knot, or how luxuriously draped the foliage of your hackle or your saddle, but how rapidly you take on the proportions of a good "fry" or how surely you possess the prepotency to transmit this tendency, or the egg-laying tendency, to your progeny, is the latter-day word of praise for the cockerel, be he Wyandotte, Minorca, or Rhode Island Red.

This upheaval in the traditions of the poultry world, has been due chiefly to the patient industry, and the imaginative foresight, of the head of the Poultry department of the Oregon Agricultural College. His experiments in breeding for egg-production brought about not only the two greatest O. A. C.'s World's Champions.

individual egg-records for a single year-291 eggs for hen "C-543" and 303 eggs for hen "C-521" - but also the greatest individual record of production for four consecutive years, 819 eggs for a Leghorn. They have shown, moreover, by repeated results running through a large number of flocks of different lineage, that the faculty of producing eggs is inherited, and may be conserved in a flock by judicious selection and breeding. Pursuing these experiments on a broad scale, he has bred up from year to year large numbers of cockerels for distribution to the poultry raisers of the State-fowls descended from good layers, and capable of transmitting the laying quality to their offspring. In this way, a far-reaching movement is inaugurated for increasing the egg-production of the entire commonwealth-not by hap-hazard practices, but by a tried and scientifically accurate method of breeding. At the P. P. I. Exposition the O.A.C. layers rapidly took their place at the head of all competitors.

Add to these striling achievements - the report of which is already worldwide-the department's discoveries in respect to housing chickens-fresh air without draughts-its discoveries in economical feeding, both for eggs and for meat, its investigations in incubation, in preparing poultry products for market and in marketing these products - and you have an idea, albeit brief and inadequate, of the comprehensive services of the department in breaking trails into new regions of the kingdom of poultry raising. 

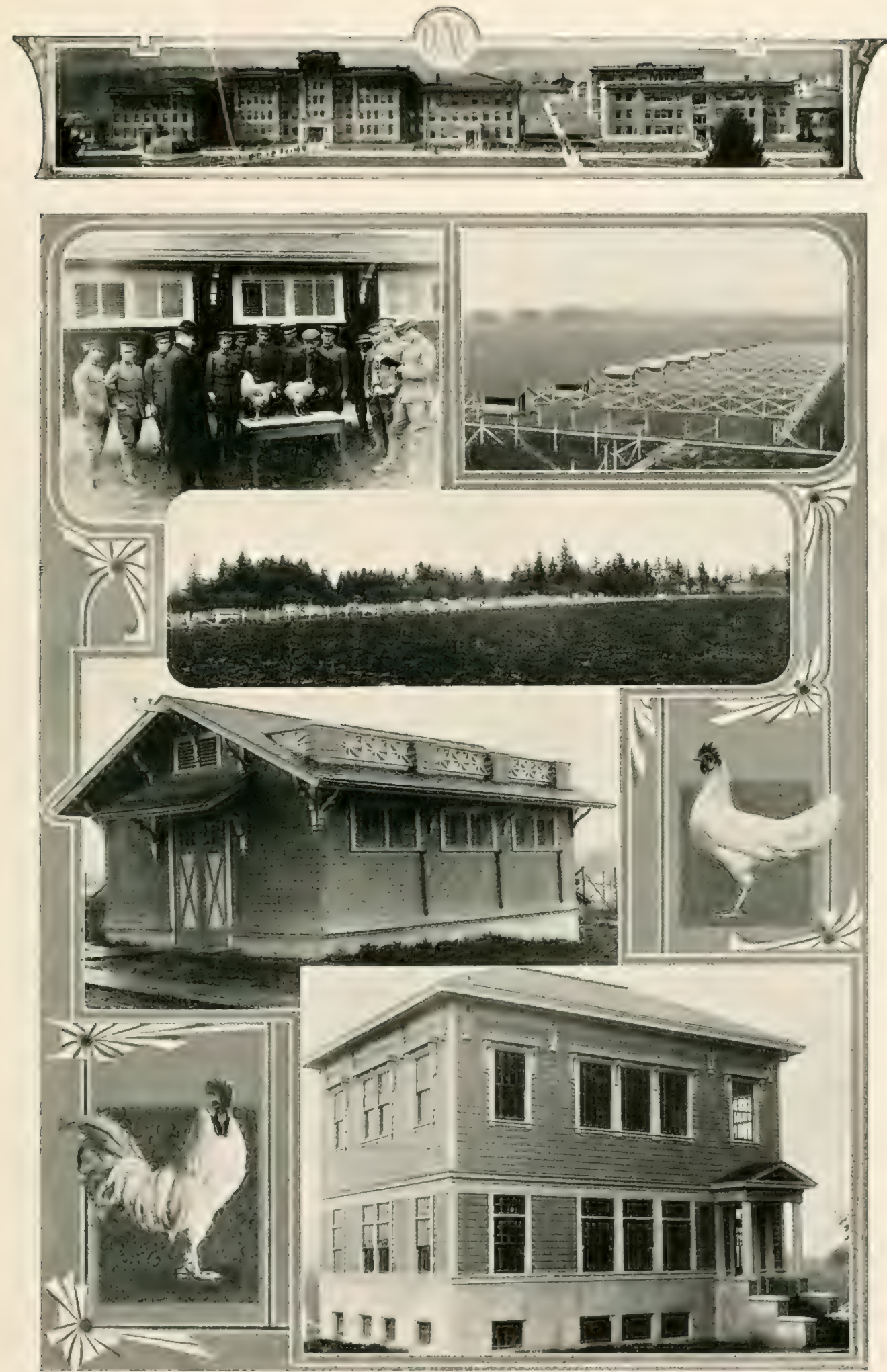

POULTRY HUSBANDRY IF

POULTRY BREEDING PENS, UTILITY POULTRY BUILDLNGS, AND JUDGING FOWLS, TOGETHER WITH THE WORLD'S LONG DISTANCE IAYER ( 819 EGGS IN FOUR YEARS) AND HER PEDIGREED SON 


\section{BACTERIOLOGY.}

The department of bacteriology has been a leader in many efforts that have resulted in better living conditions throughout the State. Its work for sanitation in dairy practices, in the handling of houstnoia wastes, and in the disposal of sewrage; its development and distribution of pure cultures of yeast, vinegar, and butter starters; its service in the inoculation of legume seed for the improvement of the crop and the nitrification of the soil, and its work with poultry diseasesall have been initial efforts in this State and have wrought undoubted benefits.

Realizing the far-reaching importance of the effect of bacteria in restoring to the soil that most essential plant-food element, nitrogen, the department has carried on a careful series of experiments to learn the particular needs of the different types of Oregon soils. It has been found, as a result of this investigation, that different types of our soils require radically different treatments in order to assist the chemical processes whereby nitrogenous organic matter is transformed by the activities of bacteria into available plant food. The application of lime, for instance, had almost an opposite effect upon bacterial activity of soils at Hermiston and Corvallis. In the soils of Clatskanie the effect of lime was found even more marked than in Corvallis, increasing the nitrifying power $400 \%$. These studies, which are preliminary to more fundamental investigations in the problem of soil fertility in Oregon, give promise of yelding scientific information of the greatest value.*

Present problems of the department deal with the activities of soil bacteria as related especially to protein matter broken down from plant tissues which are decomposed in the soil. To find out if possible which of the "end products" resulting from the breaking up of proteins in the soil, are beneficial and which are deleterious to crops, and thus to determine one of the most important steps in humus formation, is the object of a set of experiments now in progress by the department in cooperation with the department of chemistry. This is a new line of investigation, and results, when they are achieved, should be of decided value in increasing the fertility of our soils.

The department is also carrying on experimental work with a view to ascertaining the different amounts, kinds, and conditions of soil acidity which damage the growth of our leguminous plants, such as peas, beans, alfalfa, vetch, etc., and the bacteria which are necessary for the successful growth of these plants.

The work of the department dealing with poultry diseases falls under two main heads; (a) the effort to control that most prevalent and disastrous scourge to Oregon poultry, white diarrhea, and (b) a campaign for the elimination of fowl tuberculosis. Both of these diseases are so common, and have so degenerating an effect upon the vitality of the flocks which they infect, as well as so threatening an influence upon the health of human beings, that the investigations are eminently worth while. $\dagger$

"Station Bulletin 118. tCollege Bulletin No. 99. 
实.

$\ldots$ the

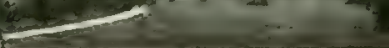
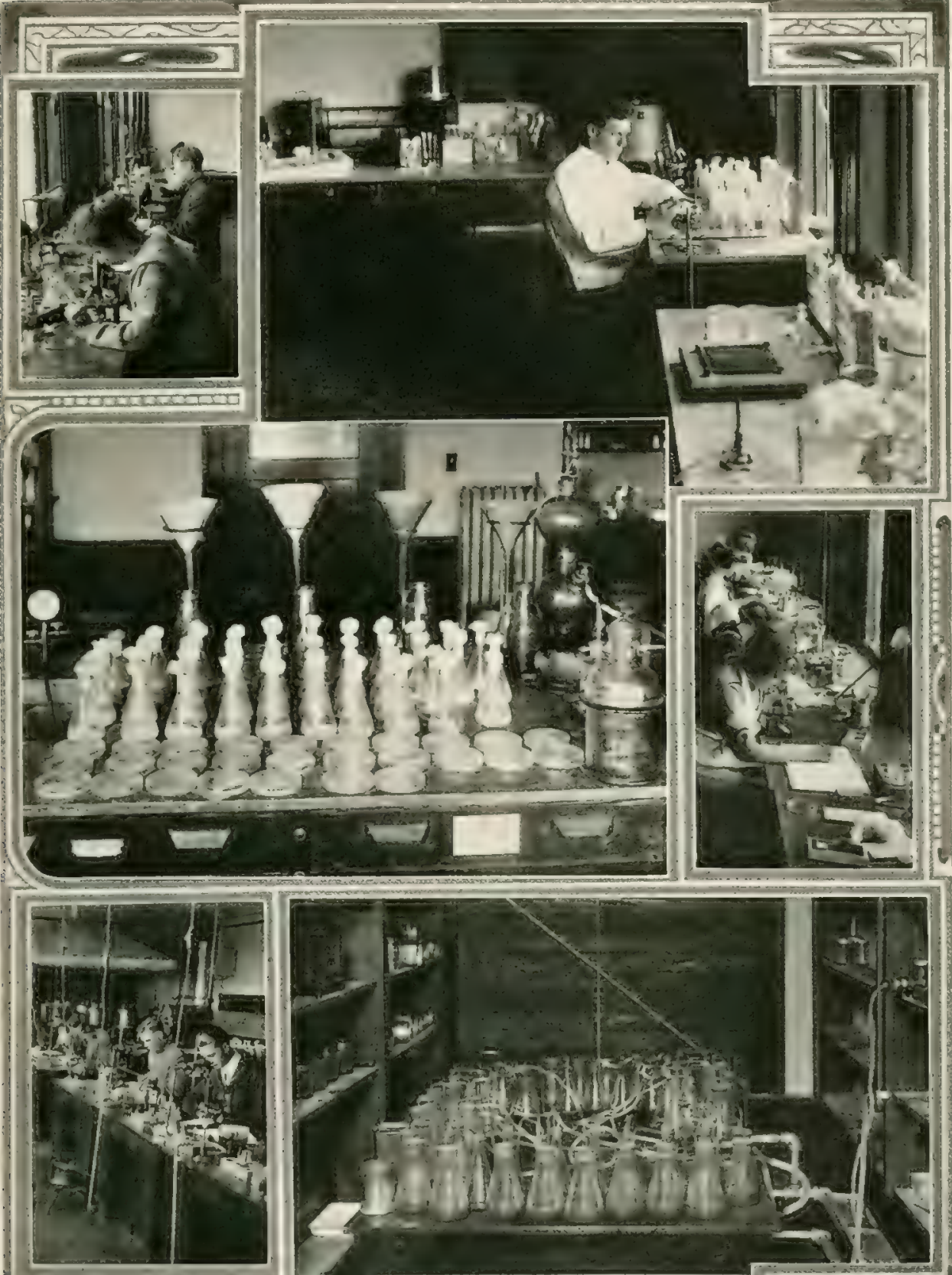

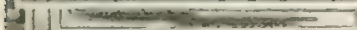

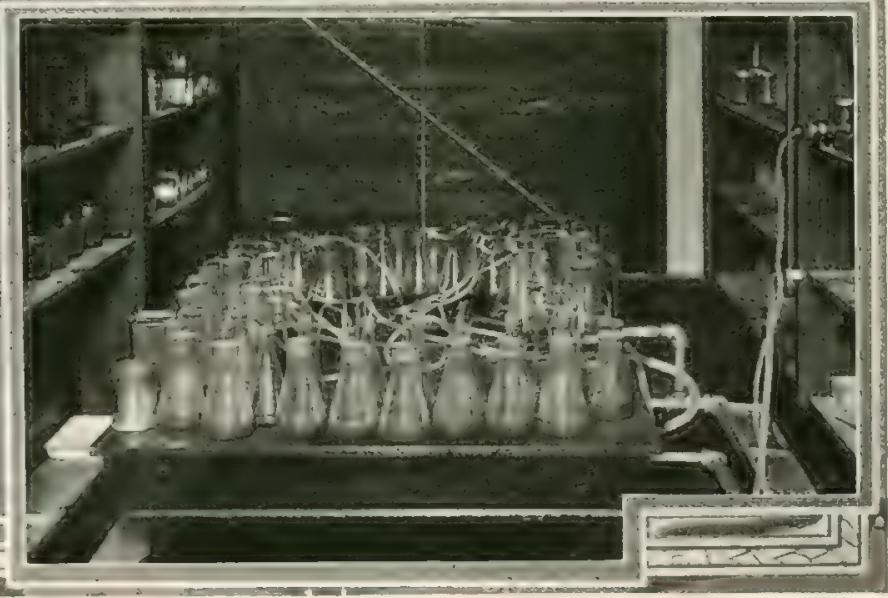

BACTERIOLOGY

SHOWING MINIATURE VIEWS OF STUDENT LABORATOILS TUGETHER WITH PICTURES OF SEED INOCULATION WORK, SOIL INVESTIGATIONS, AND SOIL TESTING 


\section{BOTANY AND PLANT PATHOLOGY.}

The department of Botany and Plant Pathology is peculiarly devoted to problems of research and investigation. Its function, like that of the department of Chemistry, is to deal chiefly in fundamental principles, in primary processes, and in the essential manifestations of plant life, both

Contributions to Science. in health and disease. It has been a leading factor in the investigation of the crop, fruit, and plant diseases of the Pacific Northwest, and through its contribution to the pathological literature, as well as its conduct of departmental work, has won general recognition as among the foremost departments of hotany and plant pathology in the entire West. As an instance of the recognition the department is receiving for its recent contributions to pathology, mention may be made of the election of the head of the department to the position of president of the first pathological association formed west of the Rocky Mountains.

Among the problems that the department has been first to investigate or first to carry into the dawn of final solution in the Pacific Northwest are Bacterial Gummosis of cherry trees, Anthracnose of apple trees and cane fruits, Fire blight of pear and quince, Peach leaf curl, Brown rot of stone fruit,

Problems that Pay Big Dividends.

Mushroom root rot of fruit trees, a Pacific Coast rust attacking pear and quince, Late blight and Scab of potatoes, and Downy mildew of lettuce, onions, tomatoes, etc. Methods of control evolved in the course of these investigations give promise of affording effectual relief from the ravages of many of them, notably that worst enemy of the young cherry tree, bacterial gummosis. While most of the investigations have not yet been concluded, they have progressed far enough to give assurance that the State's investment in this work will be repaid a thousand fold in the saving of future crops, and that our most feared diseases of plants and fruits must ultimately be routed by the vigilant and resistless warfare of science.

"The establishment of the Agricultural and Mechanical Colleges was a revolt from the older education. That education set its face toward the past, and occupied itself with books; it was the desire of the newer education to set the pupil into relations with his environment, and to teach him things as well as concepts." - Dean L. H. Bailey, Cornell University.

"The development of the experiment station in the full tide of the nation's prosperity, came $n$ response to the demand for research work and for a basis of fact scientifically attested, which would be the foundation, not only of instruction in the colleges but of improved methods on the farm. The accelerated progress in these colleges from the date of the Hatch act is too obvious to call for explanatory comment." - President W. O. Thompson, Ohio State University.

"All things considered, the outlook is for a glorious future, and the historian fifty years hence will discharge a pleasant duty in making record of the richest half-century of human progress along agricultural and humanistic lines, to the accomplishment of which the American agricultural college will have contributed its full and proper share."-Dean Eugene Davenport, College o Agriculture, University of Illinois. 


\section{1}

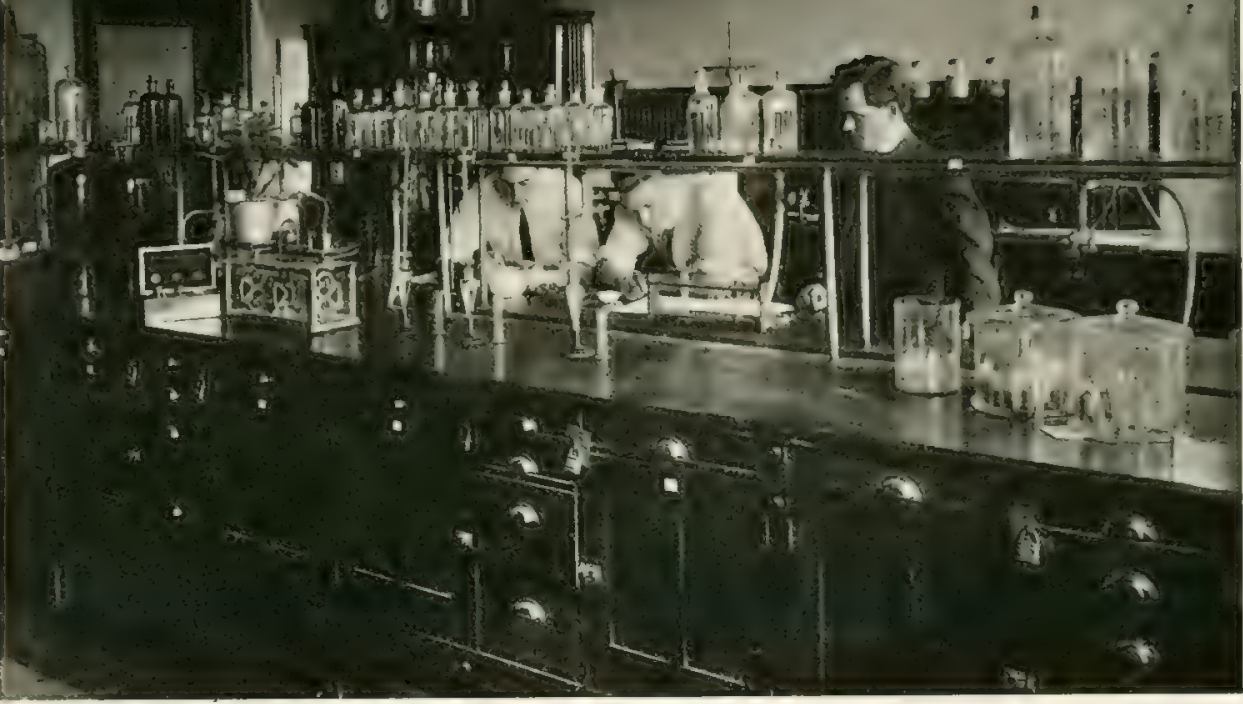

STUDENTS ENGAGED IN PLANTT PATHOLOGICAL INVESTIGATIONS

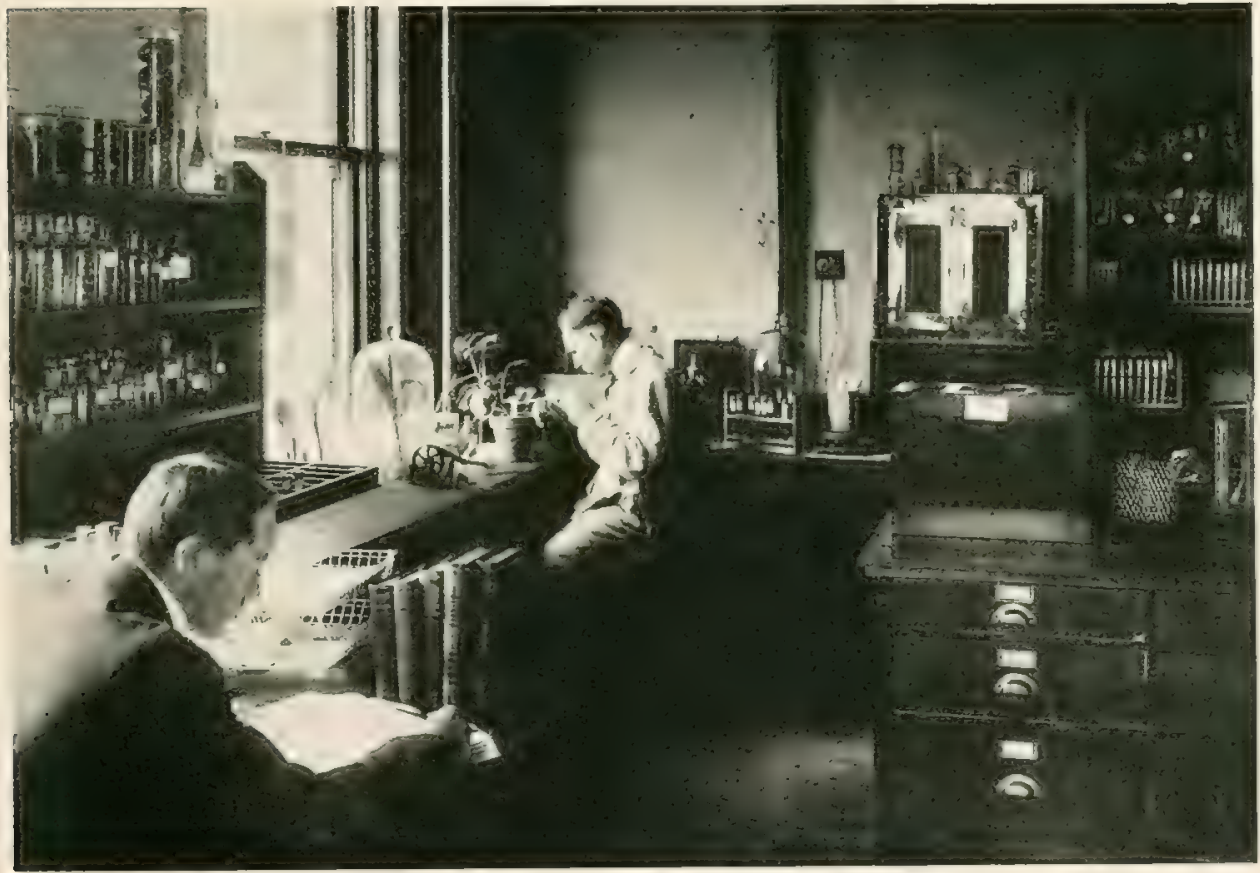

LABORATORY RESEARCHES

BOTANY AND PLANT PATHOLOGY 


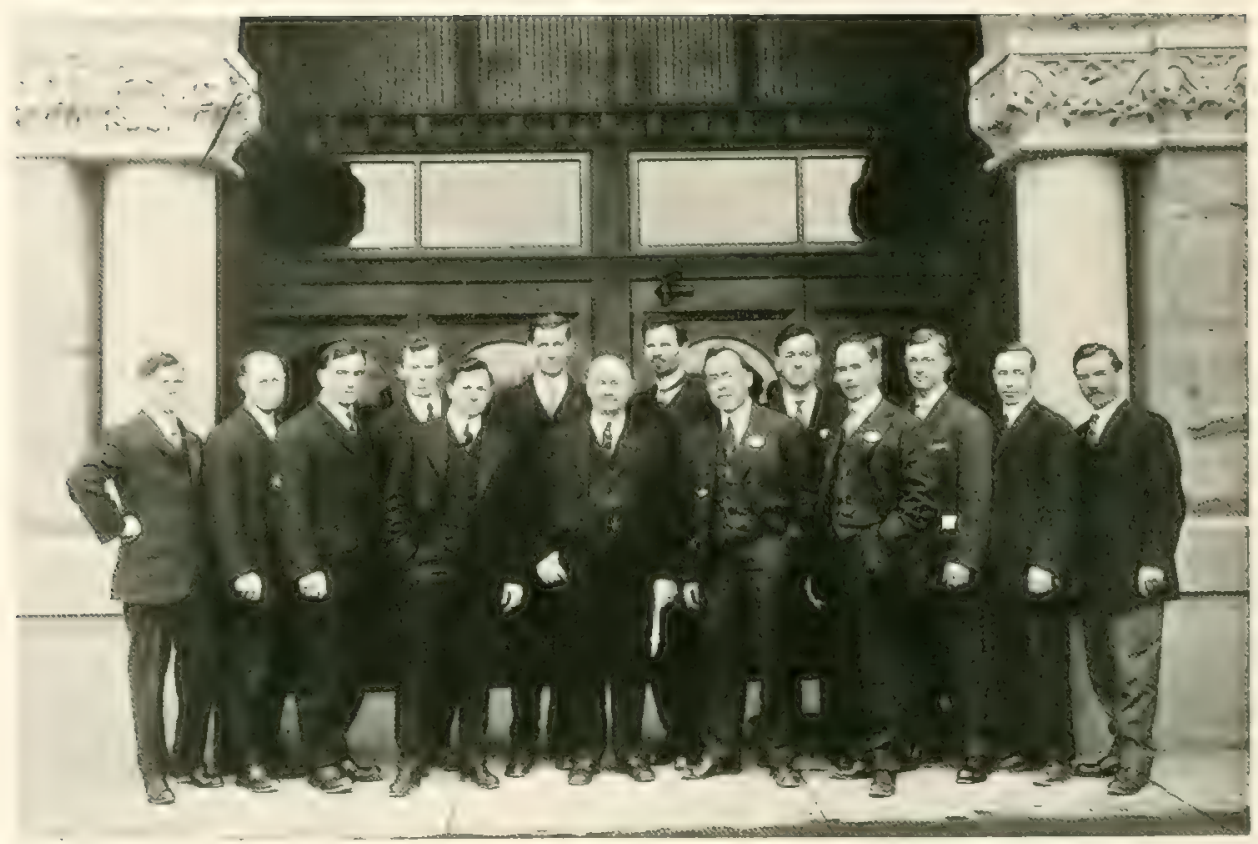

COUNTY AGRICLLTURISTS AND U. S. DEPARTMENT OF AGIRULTURE SPECIALISTS IN CONFERENCE AT THE COLLEGE

\section{ENTOMOLOGY.}

Five-sixths of all living beings are insects. Of these, by far the greater number are injurious to vegetation or parasitic upon the higher animals. Incalculable damage befalls the growing crops of each recurring season, because of the ravages of myriads of insects, many of them so small as to defy inspection by the naked eye. Without the aid of a vigilant and uncompromising warfare on the part of entomologists throughout the country insects would soon reduce the crops to the point of starvation for the human race. In a climate as mild as that of most sections of Oregon, moreover, where frosts are rare or light, the need for a constant and vigorous attack upon our insect enemies is even greater than in climates where the cold of winter slays most of the annual horde of crop pests. Hence the paramount importance of the work of the department of Entomology at the Oregon Agricultural college in protecting domestic animals and fowls, in safeguarding the crops of the field, and in clearing the orchard of its many destroying insects.

The work of the department has been notable for many years, contributing some of the most effective safeguards to the science of insect control on the Pacific Coast. Its investigations of the San Jose scale, tent caterpillars, the codling moth, strawberry root weevil, bud moth, garden slugs, onion thrips, and aphis-to name only a conspicuous list of researches-have made positive contributions to the knowledge of these insects and the methods of controlling them. The department has also done constructive work in the study of bee-keeping in Oregon, and is exerting a stimulating influence in fostering all profitable phases of the apiary industry. 


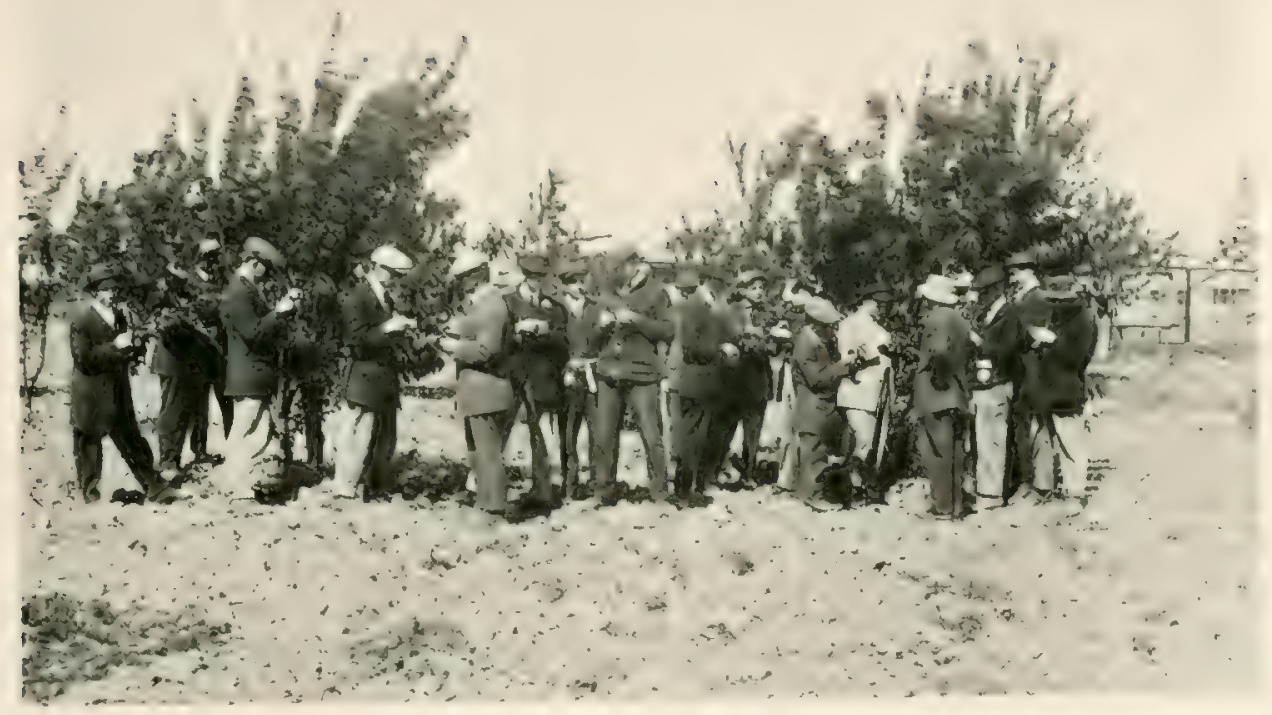

FIELD WORK IN ENTOMOLOG

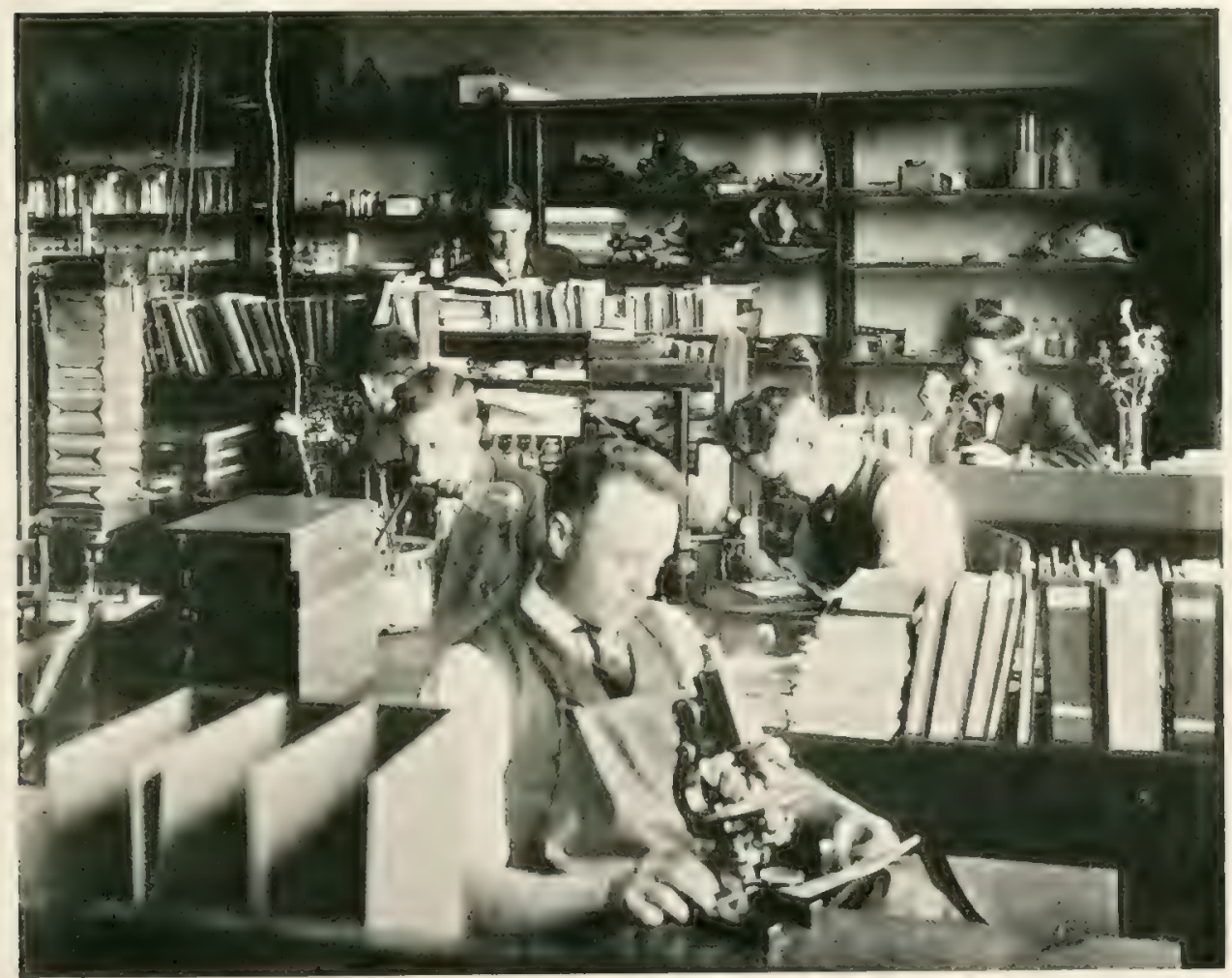

A BUSY LABORATORY IN PERSCIT OF INSECT PESTS AND IN THE WORK OF FOSTERING THE HELPFUI, INSECT

ENTOMOLOGY 
The peculiar charm in the study of biology lies in the pursuit of knowledge in the field of living things, the study of life itself; and the study of zoology has an even more vital fascination for man because the intimacies of human interest are brought so acutely in contact with the problems of animal life.

A zoologist is first of all an observer. His primary business is to see things, to take note of occurrences in the animal world, to examine into the nature of animal phenomena and to record these observations. His secondary business is to search into the causes of zoological phenomena. He must examine the mechanism of the organism, determine its function, analyze its composition.

For original study of zoology, Oregon is a virgin field. Here, more conspicuously than elsewhere, the fields of zoology still remain unexplored. Oregon's vast areas of valley, mountain, and plain are as yet searcely touched by the systematist

Oregon's Special Problems. and the ecologist. As to the birds and mammals of the State, who knows what they are? New species are being reported every year. Science is crying for more facts in this field. The economic interests of the State demand a detailed knowledge of the distribution, habitats, and habits of these animals of the field, the forest, and the waters. Does the balance sheet of the Brewer's Black Bird show a profit or a loss at the end of the year? What does the mole eat? Does the coyote kill off enough jack rabbits to warrant keeping him at large in the back lot? Do the salmon hatched in one stream return to the same stream to spawn? What is a "Salmon Trout"? What valuable but unutilized fishes live in the sea? Do the sea lions destroy food fishes? Whoever can answer one of these questions to the satisfaction of science will not go unrewarded.

Other zoological problems that are conspicuously worth investigating for the scientific anpirant of the Pacific Northwest are the following: What are the conditions that render the Eastern oyster incapable of reproducing in the Pacific waters? What factors are involved in determining the routes Questions that
Challenge Solution. of seasonal migrations among birds? What are the effects of various poisons and narcotics on the vital capacities of various mammals? What is the influence of untoward environment in heridity? How are form and function correlated in heridity? How do temperatures, pressure, and light affect the development of animal organisms? He who has the perseverance to pursue any one of these problems to the point where a ray or two of light may filter through, will be adequately taken care of by the scientific world. 

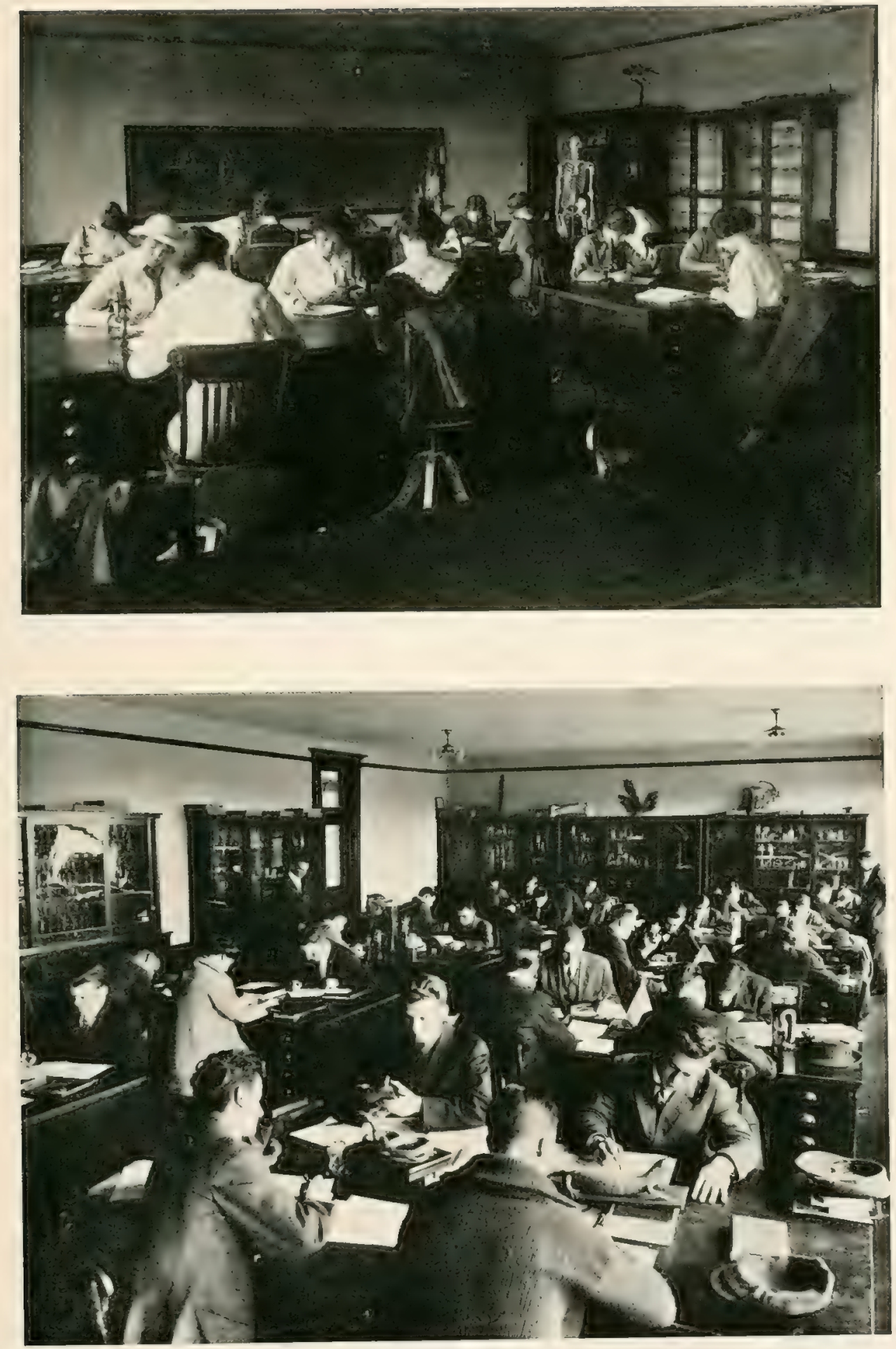

ZOOLOGY

TWO LABORATORY EXERCISES IN DIFFERENT COURSES OF STUDY 


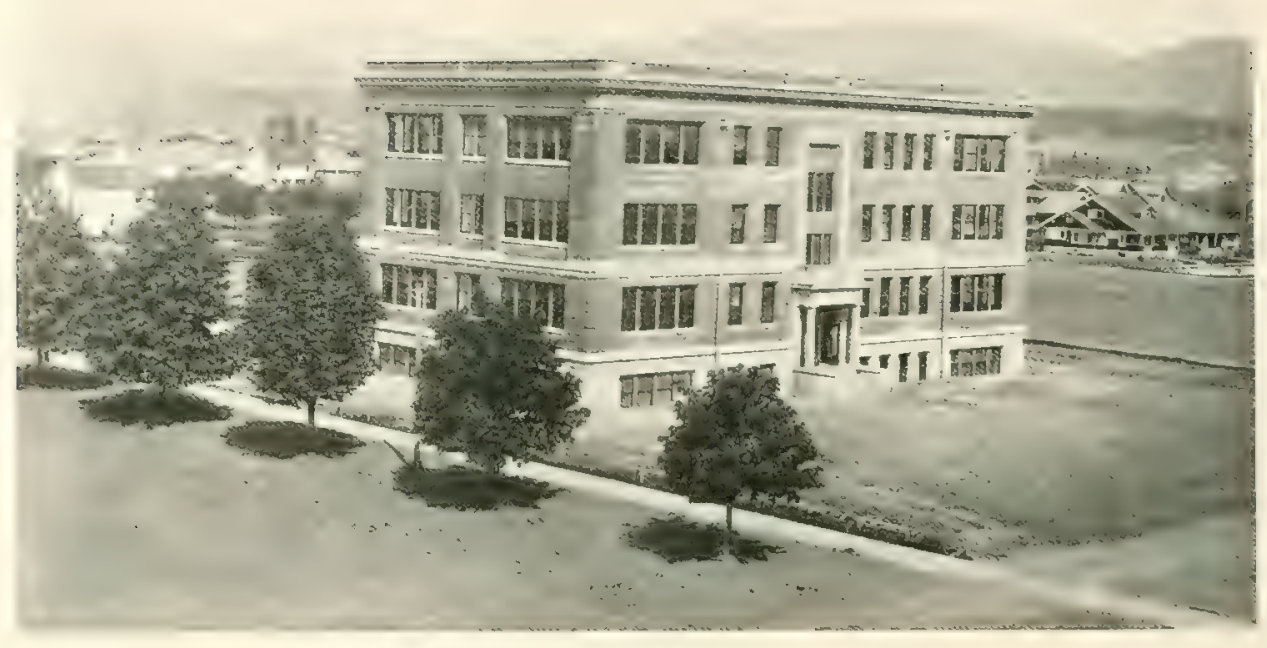

EAST WING OF HOME ECONOMIS BULUING

\section{CHEMISTRY.}

No science during the past century has contributed so much to the fundamental progress of agriculture as has chemistry. It has revealed the true composition of the soil and its relation to plant food. It has discovered the methods of utilizing plant food and of conserving it for future growing seasons. It has established, by experiment, the habits of plant growth and the chemical changes that take place during plant growth. It has successfully demonstrated the laws of animal nutrition, and has thereby enabled the animal husbandman and the dairyman to exercise great economy in the use of nutrients. It has revealed the methods whereby organic nitrogen is prepared for plant food, and some of the ways in which atmospheric nitrogen enters into organic combination. It has been intimately associated, in short, with nearly every line of agricultural progress, and is still pioneering the way to new, more profitable, and more inspiring conquests.

The department of Agricultural Chemistry at the College has shared liberally in the original contributions of this science to the betterment of agriculture, and of human life in general. The mere enumeration of the bulletins which it has issued, either independently* or in cooperation with other departments of the College, would suggest the scope and worth of its work. But its services go beyond the subject matter of such investigations, which are fundamental to progress in many other lines of effort at this institution, and often in the laboratories of other similar institutions throughout the world. The department, in short, is a good example of those service departments of an experiment station whose work, as far as ultimate results are concerned, is so intricately involved with that of other departments, that its true value may never be appreciated by the public, or even kmown to many beyond the circle of scientific workers.

"One fourth of all the bulletins of the Station have been the work of the station chemists. 

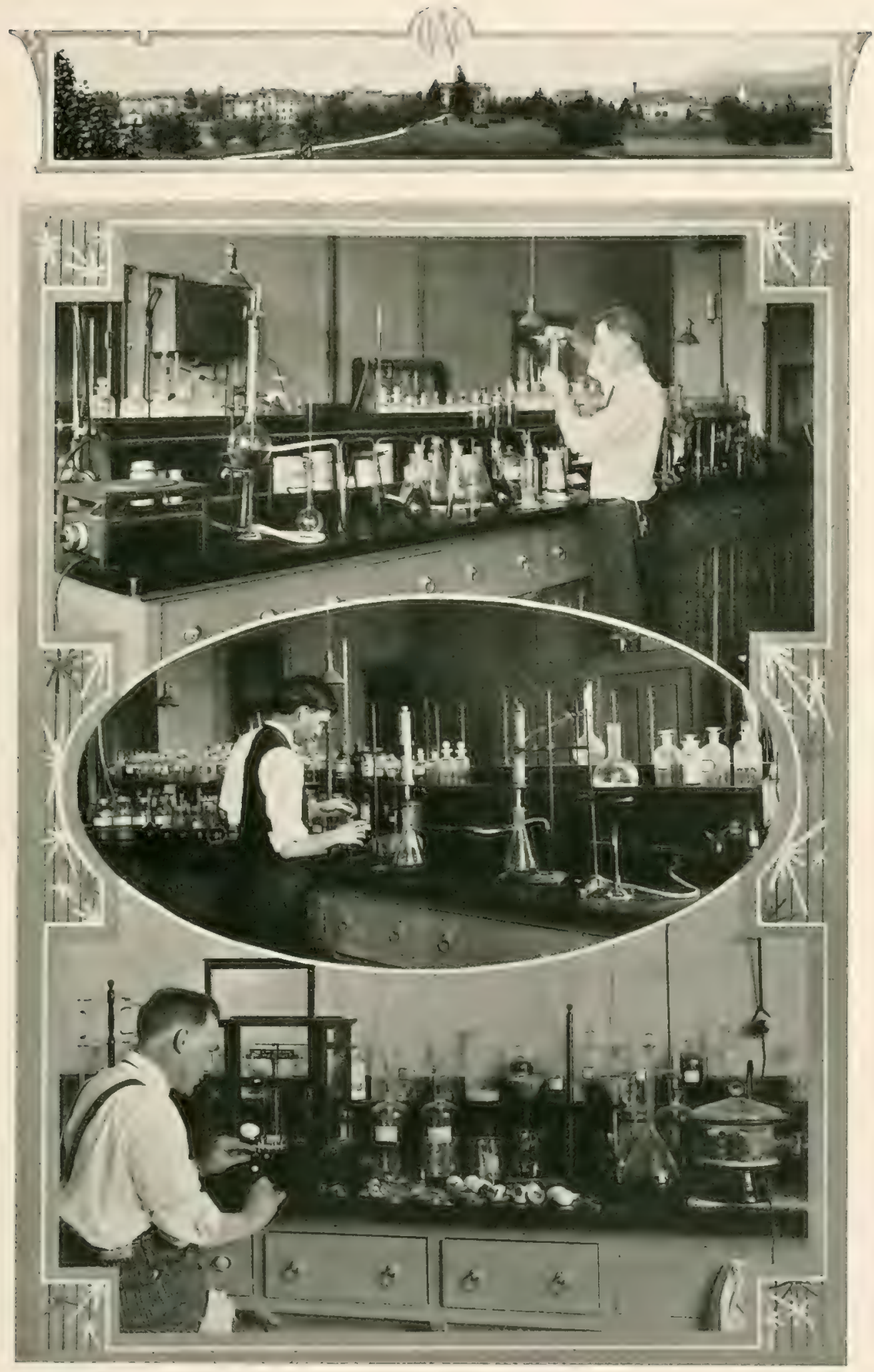

AGRICULTURAI, CHEMISTRY

INVESTIGATION WORK WITH SOILS AND WITH INCUBATION OF CHICKS 


\section{SCHOOL OF ENGINEERING.}

Exceptional opportunities for pioneering service in Engineering are afforded by Oregon in particular, and by the Pacific Northwest in general. Conditions here are still in the making, and few of the phases of engineering work have been

Peculiar Needs in Oregon. reduced to extreme specialization as in the more settled communities of the East. The departments of Engineering that are conspicuously needed in the upbuilding of Oregon's resources, especially in the utilization of her great natural wealth, are mechanical, highway, irrigation, sanitary, electrical, and civil. The mechanical industries are still in their infancy in this State so far as great manufacturing enterprises are concerned, but the need for college-trained mechanics, especially those possessed of initiative and constructive ability, is far greater than the supply.

The school of Engineering therefore aims to train men primarily for all-around duties in machine shops and mechanical trades. A feature of work in this department that is peculiarly constructive, involving creative skill and accurate

Designing and Making Castings. finishing of castings for College-built machines. Patterns for the castings are designed and constructed by the students in the wood-working shops. They are then set up and molded in sand at the foundry, where the "casting" is periodically done. "Pouring a heat," as the process of casting is called, makes a picturesque and interesting spectacle, often accompanied, at certain stages of the work, with displays of fire-works altogether thrilling. When cooled, the castings so made at the foundry are cleaned of all sand and freed from irregularitis.s. Thus prepared, they are taken to the machine shop, where they go through various processes of sawing, drilling, turning on the lathes, planing, or other treatment, according to the respective purposes for which they were made.

By this interesting but exacting procedure, students in the regular and vocational courses have built, in the course of the present college year, a large hydraulic testing machine for the Experimental Engineering laboratory, five speed lathes

Results and Purpose. for the pattern shop, two emery-grinding stands, one vertical gas engine, one horizontal gas engine, several jack screws, varying in capacity from one to three tons, castings for a stamp mill, and for a mortising machine, as well as a large number of castings for general repairs and construction work about the College. The object of this work is to stimulate constructive ability in the students, to furnish them with specific, practical, task such as they would encounter in the mechanical industries existing in the West today, and to develop responsibility, control of machinery, and a power of definite achievement.

The work is specifically laid out for a year in advance, and it progresses with 

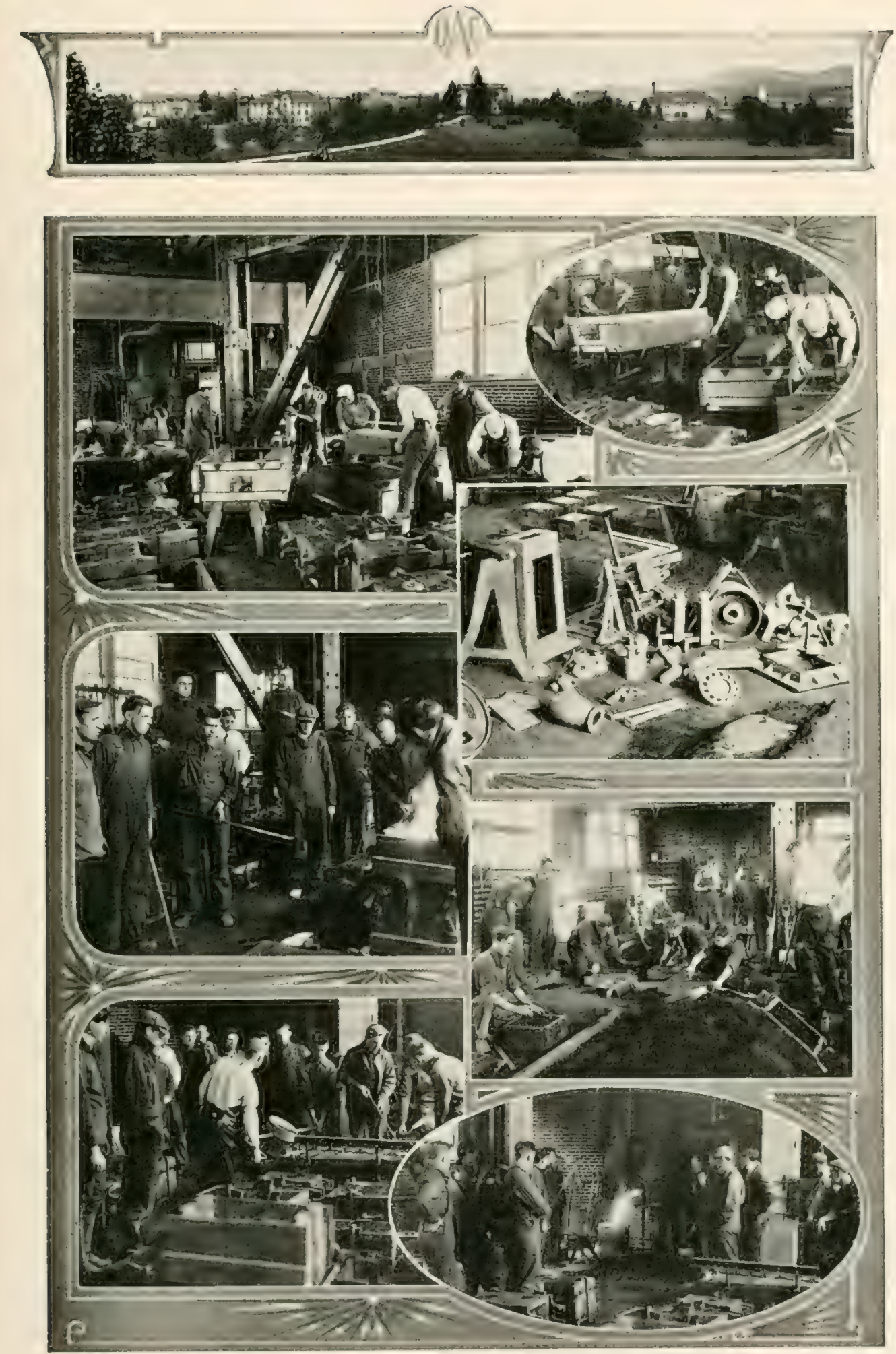

FOUNDRY

ILLUSTRATING STERS IN THE HANDLING OF MOLDS, "POURING A HEAT," AND 
the regularity that characterizes any great business concern. Much of the work is carried on by vocational students, who thus gain a practical working knowledge

Vocational Aspects. of the processes and machinery that belong to the iron-working and wood-working industries as they are conducted in the Pacific Northwest today. The instruction employed is not such as would be found in the trade schools of the East, where students are fitted for some particular task in a factory; it is a much broader type of training, involving larger initiative, a wider responsibility, and more versatile resourcesqualifications that are conspicuously needed in the business of Oregon and neighboring states, where factories are few, but where all sorts of engineering and mechanical activities, constantly under way and constantly increasing, have to be carried on under rather elementary conditions.

Highway engineering is rapidly taking prominence in Oregon, where cooperative movements for permanent highways are already making notable progress, and where individual communities are vying with one another in their effort to

Highway Engineering. lay a proper foundation for transportation. In Oregon, indeed, interest is more than keeping pace with the general interest throughout the country, especially in an effort to replace temporary work with enduring highways. In 1911 one hundred and forty-two million dollars were expended by the various states of the Union on public roads, only a small fraction of which was for permanent structures. In Oregon during 1914 it is estimated that four million dollars were spent on the roads.

In the face of such large expenditures, it is evident that some pioneer services are necessary to determine how fully the results are justifying the outlay, and how such considerable sums can be spent to better advantage. The College is doing constructive work in this great campaign for permanent highways, and is ready to give assistance to any community in launching its organization for the work.

Irrigation engineering, including sanitary and drainage engineering, is necessarily important in a State where large areas of land have been made wondrously productive under irrigation, where an abundance of streams and springs make

Irrigation

Engineering. possible in many a rural community the establishment of individual water systems, including sewers, and where the heavy lowlands of some of the great valleys await only the establishment of proper tiling systems to become as productive as the best of soils. Hence the instruction in hydraulies, which is made especially convenient by the proximity of the Willamette and Mary's Rivers, Oak Creek, and the Mill Race, as well as by means of the Station's irrigation plant, is given a distinetly practical turn, along with the essential instruction in theoretical principles. Throughout all the courses in irrigation engineering the students are taught to attack actual problems, such, for instance, as the effect of rainfall on the stream flow and underground water supply of evaporation; causes of waterlogging of 

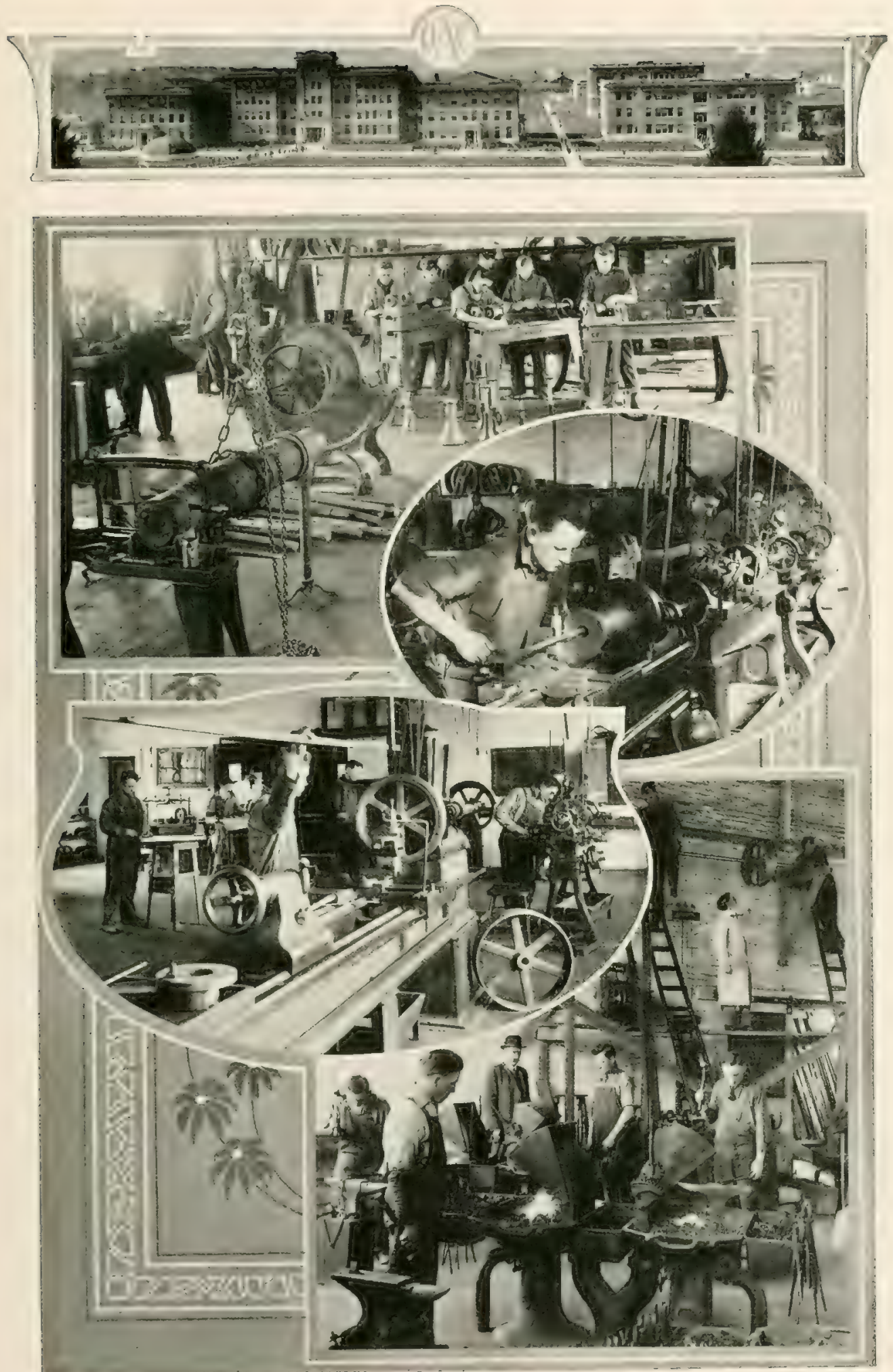

MACHINE SHOPS

SHOWING TOCATIONAL STUDENTS FINISHING CASTINGS MADE AT THE FOUNDRY, ASSEMBLING THE PARTS OF MACHINES, AND ERECTING MACHINERY 
the soil; the formation of alkali deposits on irrigated lands; the duty of water in irrigation; the proper location of irrigation systems and irrigation structures such as dams, flumes, gates, and measuring devices, as well as the design of dams and the location of reservoirs.

The department recently isisued a bulletin, in conjunction with the department of Bacteriology, on Septic Tanks and Absorption Systems for rural homes.*

Water power in most sections of Oregon is convenient and abundant. Mountain torrents, great waterfalls, and powerful rivers offer a compelling challenge to the inventive workman as well as to the electrical engineer. Hydro-electric

Electrical Engineering. systems, varying from a crude coordination of an overshot waterwheel and a small dynamo, to the most compact and finished of modern generating plants for household and farm purposes, are found here and there throughout the State, even in the most remote situations. Several commercial generating plants of immense capacity have already been installed for the general distribution of light and power, and electric railroading has gained a secure footing in the more populous sections of the State. Under these conditions, coupled with the extensive use of electricity in city communities, the field for electrical engineering in Oregon is altogether promising. Its invitation to aggresive leadership on the part of the college-trained man, is yearly growing keener, as population and industrial enterprises increase. The adequate utilization of the millions of horse-power now tumbling into useless foam at the foot of our many waterfalls, so that they shall yield the largest efficiency at the least cost, so that natural advantages shall not be sacrificed, and that the largest good shall come to the largest number of people, is a task in which the College is doing constructive service. Already the revolutionary effects of a larger use of electrical energy are becoming apparent in the lives of our people-in improved communication and its consequent social advantages, in larger comforts, in quicker and better transportation, and in a more convenient and refined mode of life.

Experimental Engineering, which is chiefly in the nature of a service department for all the other departments of engineering, mining, and forestry, is aesigned to introduce the student to the processes of engineering investigation.

\section{Experimental} Engineering. engines, water wheels, pumps, air compressors, and other power machinery; how to determine the strength of building materials, including timber, metal, and cement; how to calculate and verify different means of power transmission; how to determine the efficiency of various road-building materials; how to measure water for irrigation, and how to work out problems in irrigation, logging, reinforced concrete, etc. The department bas the usual massive and exact equipment for this work, which is one of the most responsible phases of modern engineering instruction. 

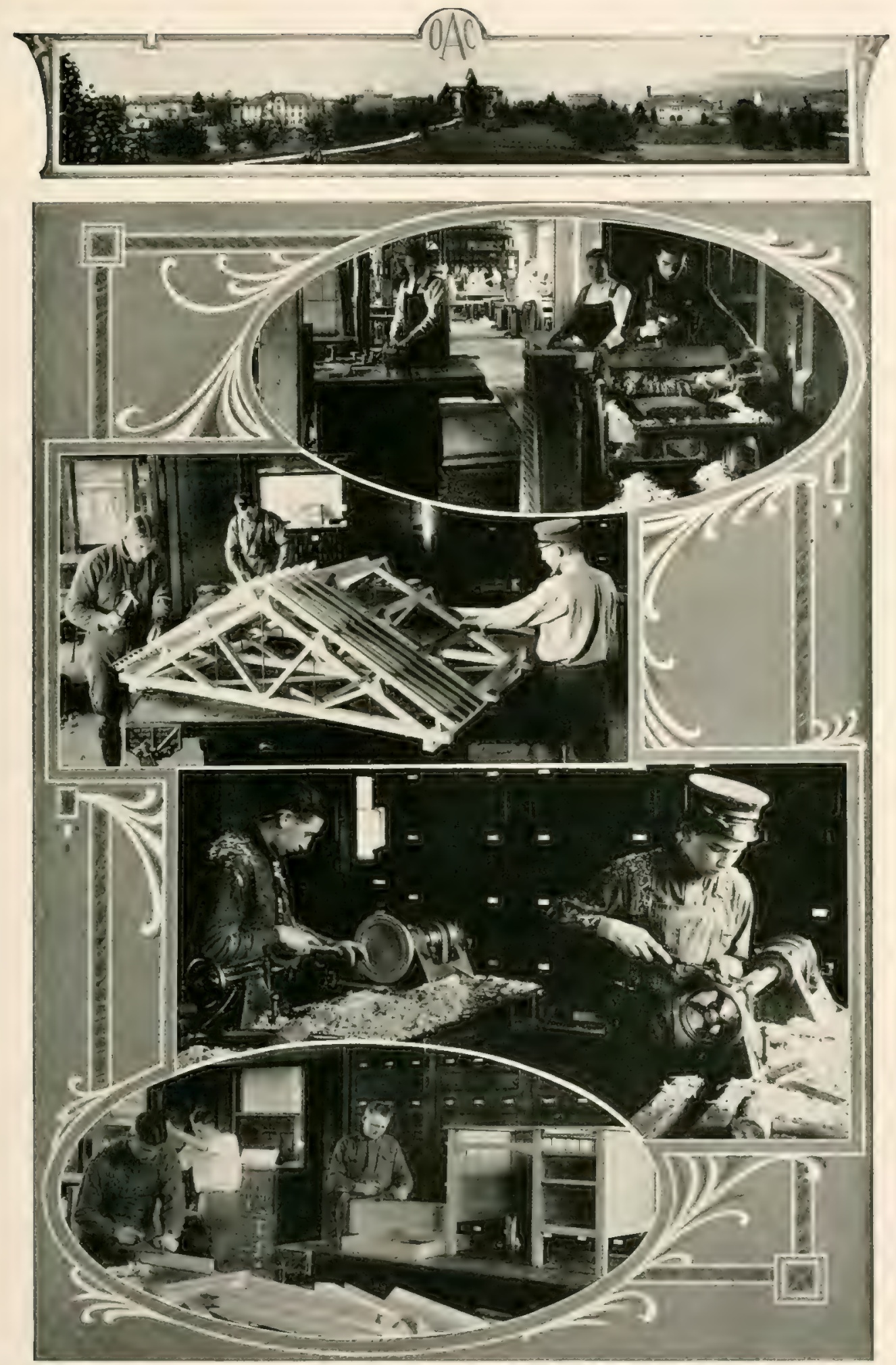

WOOD SHOPS

SHOWING VOCATIONAL STUDENTS AND OTHEKS AT WOKK WITH THE PLANER,

THE LATHES, AND WITH HAND TOOLS 

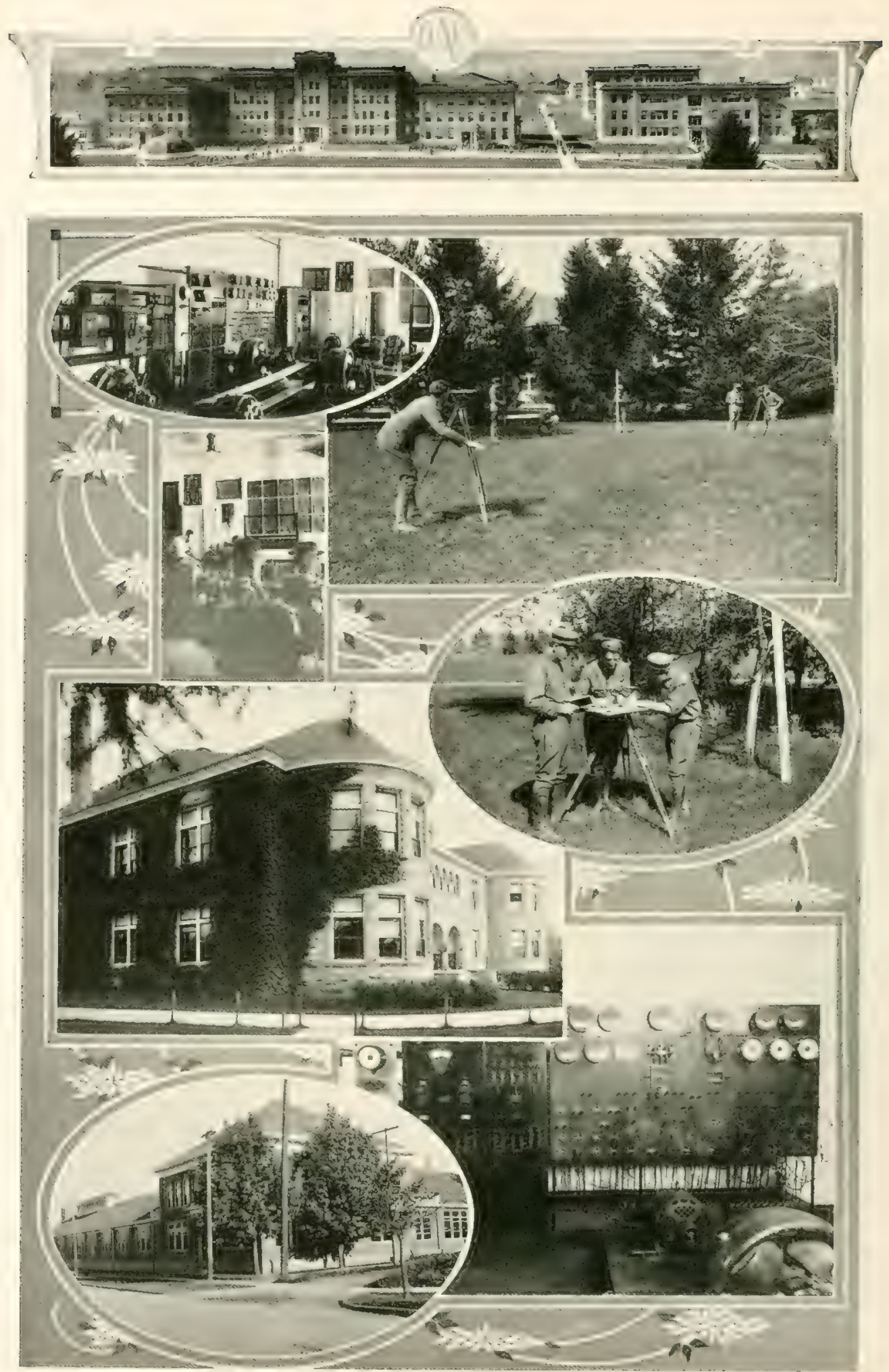

CIVIL AND ELECTRICAI, ENGINEERING

SHOWING GLIMSES OF BUILDINGS, LABORATORIES, AND FIELD EXFRCISES 

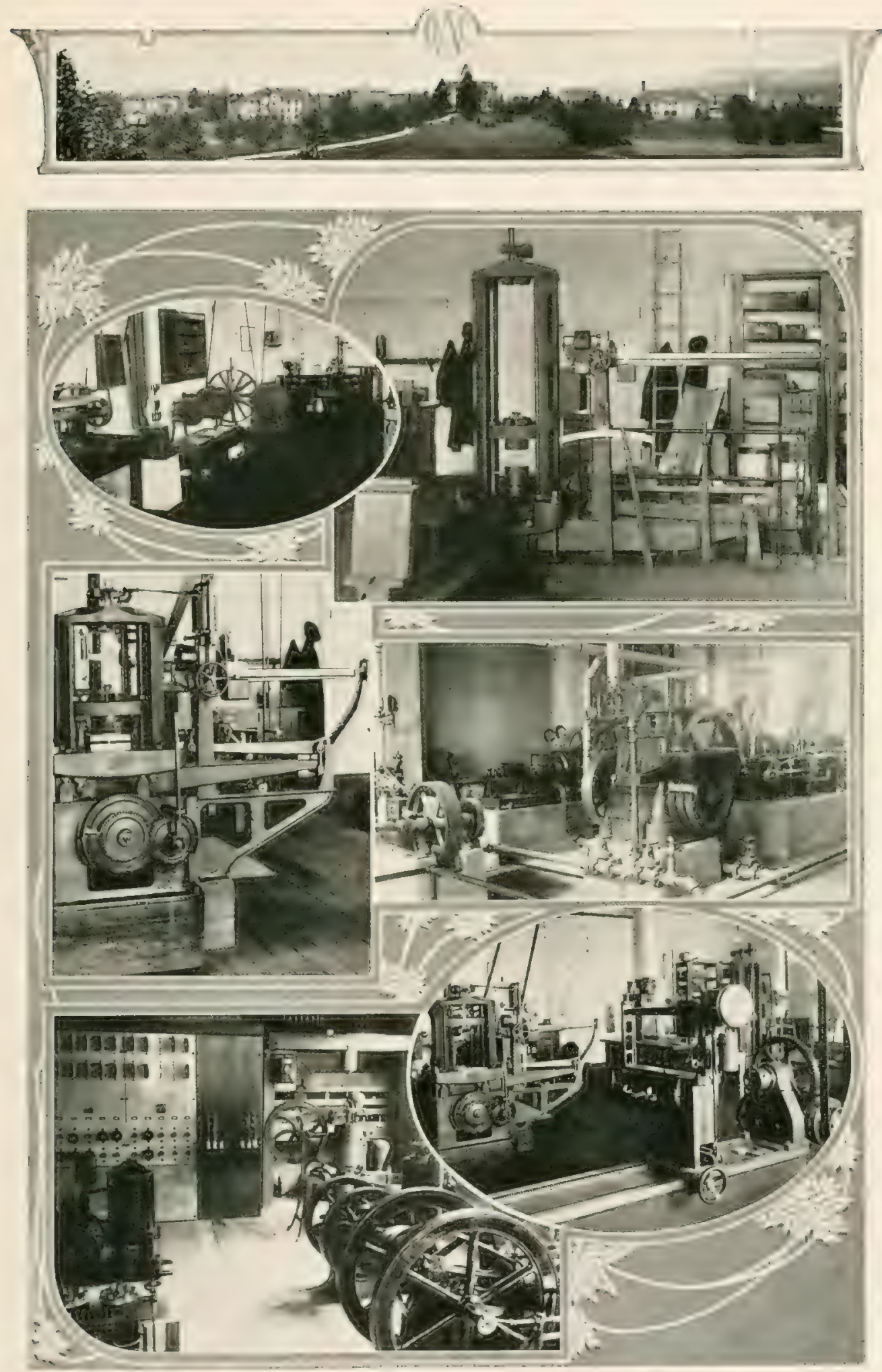

EXPERIMENTAL ENGINEERING

SHOWING VIEWS OF THF DEPARTMENT'S THREE LABORATORIES 


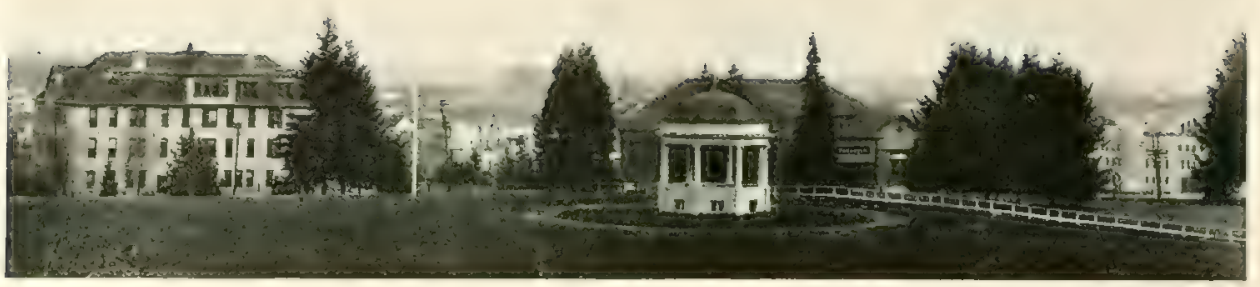

\section{SGHOOL OF FORESTRY.}

Oregon is the queen of the timbered States of the Tnion. Her mountain ranges are plumed with a wealth of Douglas fir, spruce, hemlock, cedar, and yellow pine: her valleys are majestic with primeval forests of the tallest and straightest of cone-bearing trees. One-sixth of all the standing timber of the United States is massed within the borders of Oregon. Her national forests alone contain an aggregate of over 130 billions of feet, board measure, while this is less than onethird of the merchantable timber of the State. A triumphant future awaits the development of the lumber business of Oregon, conserved and directed by an intelligent regard for the science of forestry.

The Oregon Agricultural College has the most fortunate field in America for the development of a great school of forestry. The abundance and variety of timber in the State, the proximity to the College of two great national foreststhe Santiam and the Siuslaw-the forest holdings by the State, and by the city of Corvallis, as well as the immediate neighborhood of logging camps, and sawmill operations, make up an environment for the study of scientific forestry that cannot be duplicated elsewhere in America.

The School of Forestry at the College, like the lumber business of the State, is still barely at the threshold of its career. It has had pioneering service to do, amid pioneer surroundings; and in its campaign for forest protection, on the one hand, and for a proficient and progressive training for Oregon's young foresters, on the other hand, it has met with the good fellowship and cordial cooperation of the leaders in the timber industries of the Pacific Northwest. In conjunction with the State Board of Forestry, the school is exerting a wide and penetrating influence for the conservation of the State's abundant heritage in timber; in cooperation with some of the leading loggers of Oregon and Wasbington, it is working out regular programs for giving to the students in Logging Engineering the practical experience they so seriously need, while at the same time affording 

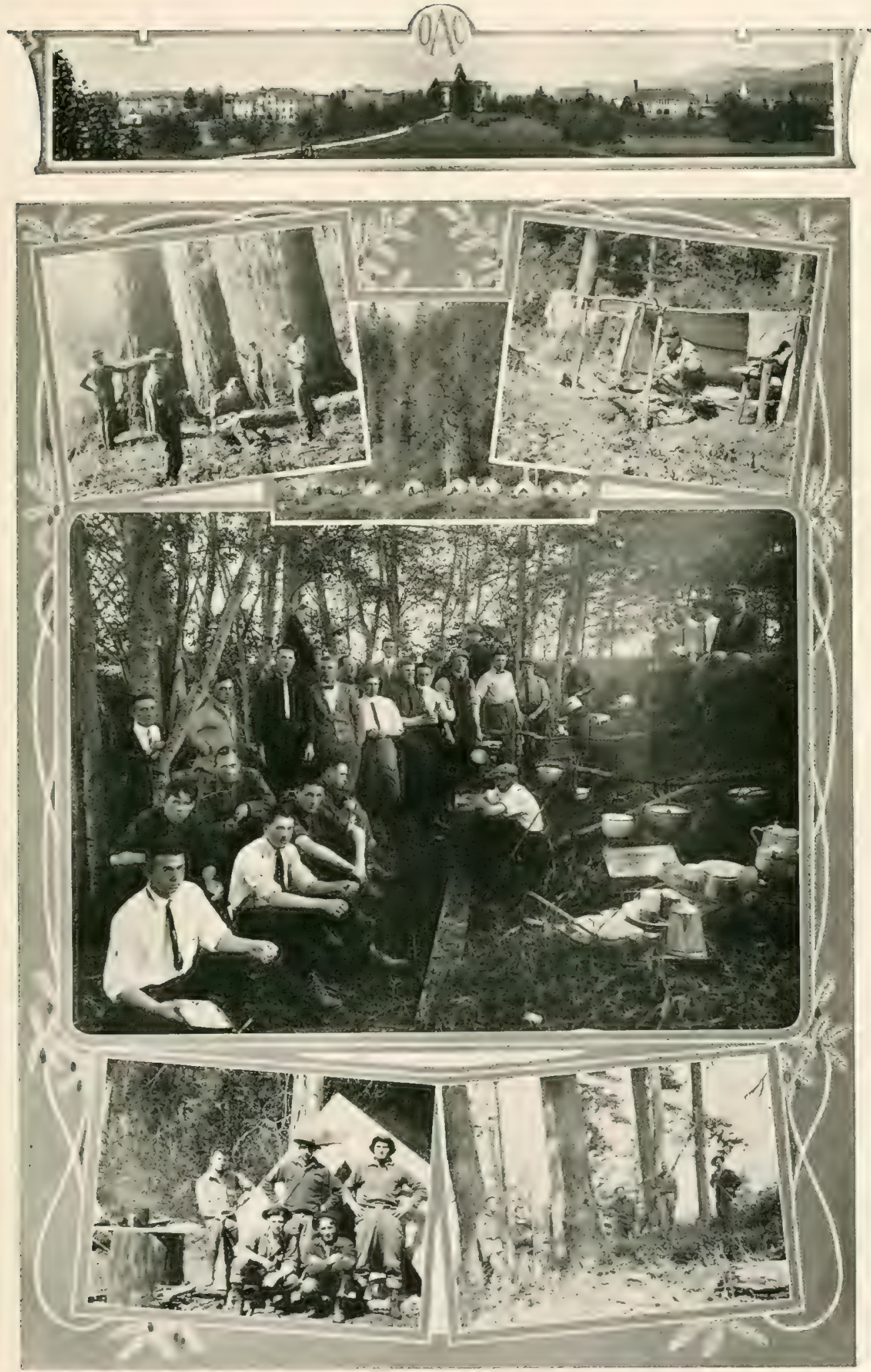


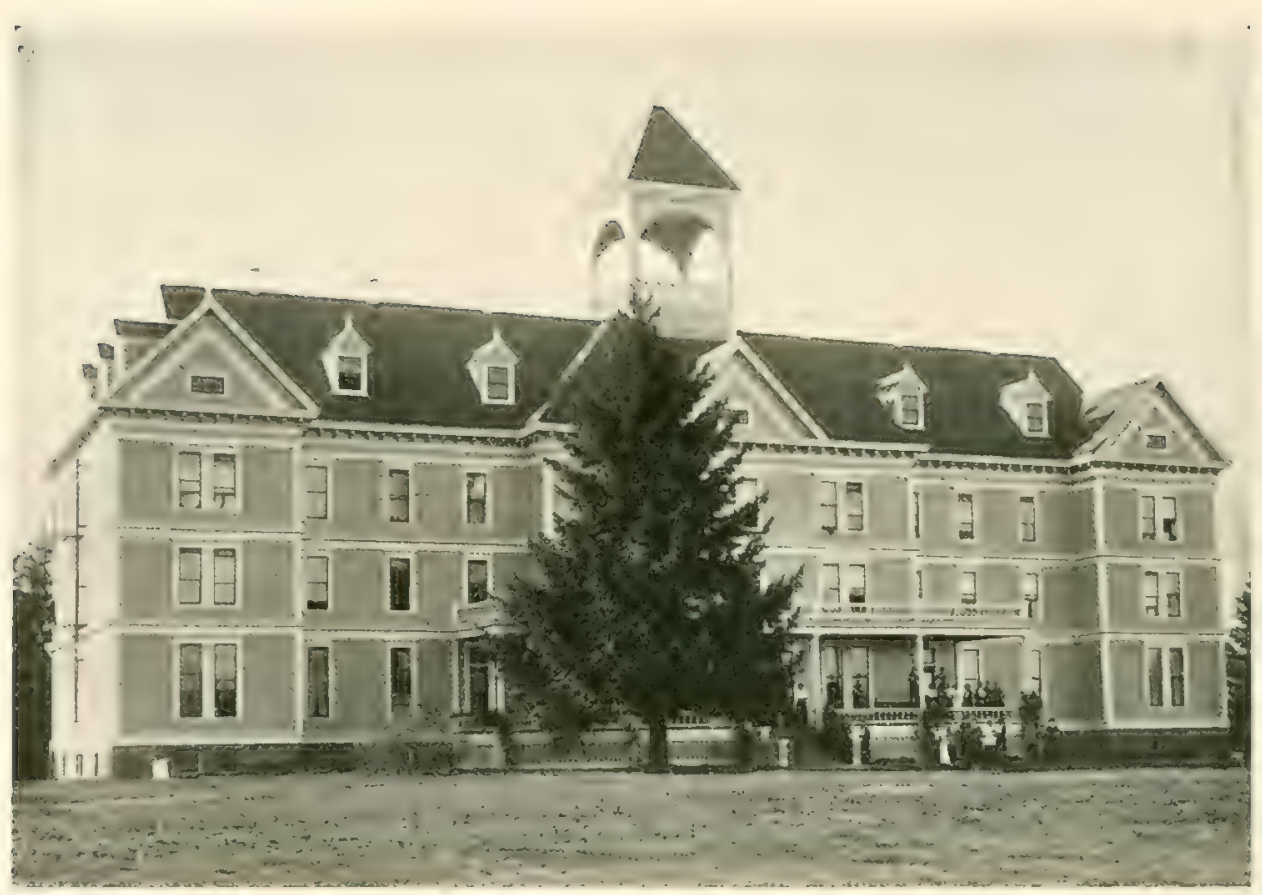

CAUTHORN HALL, WOMEN'S DORMITORY

them employment during their vacations, and giving the loggers the services of trained and ambitious workers. In association with the representatives of the national Forest Service, it has undertaken, each spring, a ten-days' field trip for work in pratical surveying, mapping, and timber cruising in the national forest.

Thus, by a policy that seeks the cooperation of all the varied interests that ale responsibly concerned with the timber and forest resources of Oregon, as well an by a plan of instruction that supplements the most authoritative features of the theory of forestry with the most vigorous, business-like, and practical experience in the field, the school of forestry strives to make its work not only immediately effective but permanently and harmoniously constructive.

Some day, not very remote now, in view of the rapid depletion of the timbered areas of the states east of the Rockies, the logging and lumber industries in Oregon will receive a tremendous impetus. Logging camps will multiply, mills will incredse in numbers and magnitude, and such plants as those for wood distillation, timber preservation, and lumber finishing, will add their busy hum to the intermittent whine of the huge saws, the roar of the log carriage, and the crash of piling boardw under the guidance of the lumber graders. To be ready for that day, and to meet its responsibilities in the light of a secure future for Oregon's forest resources, is one of the functions of the School of Forestry, which offers to the young men of the Pacific Northwest exceptional opportunities for leadership in this virile and fascinating profession. 


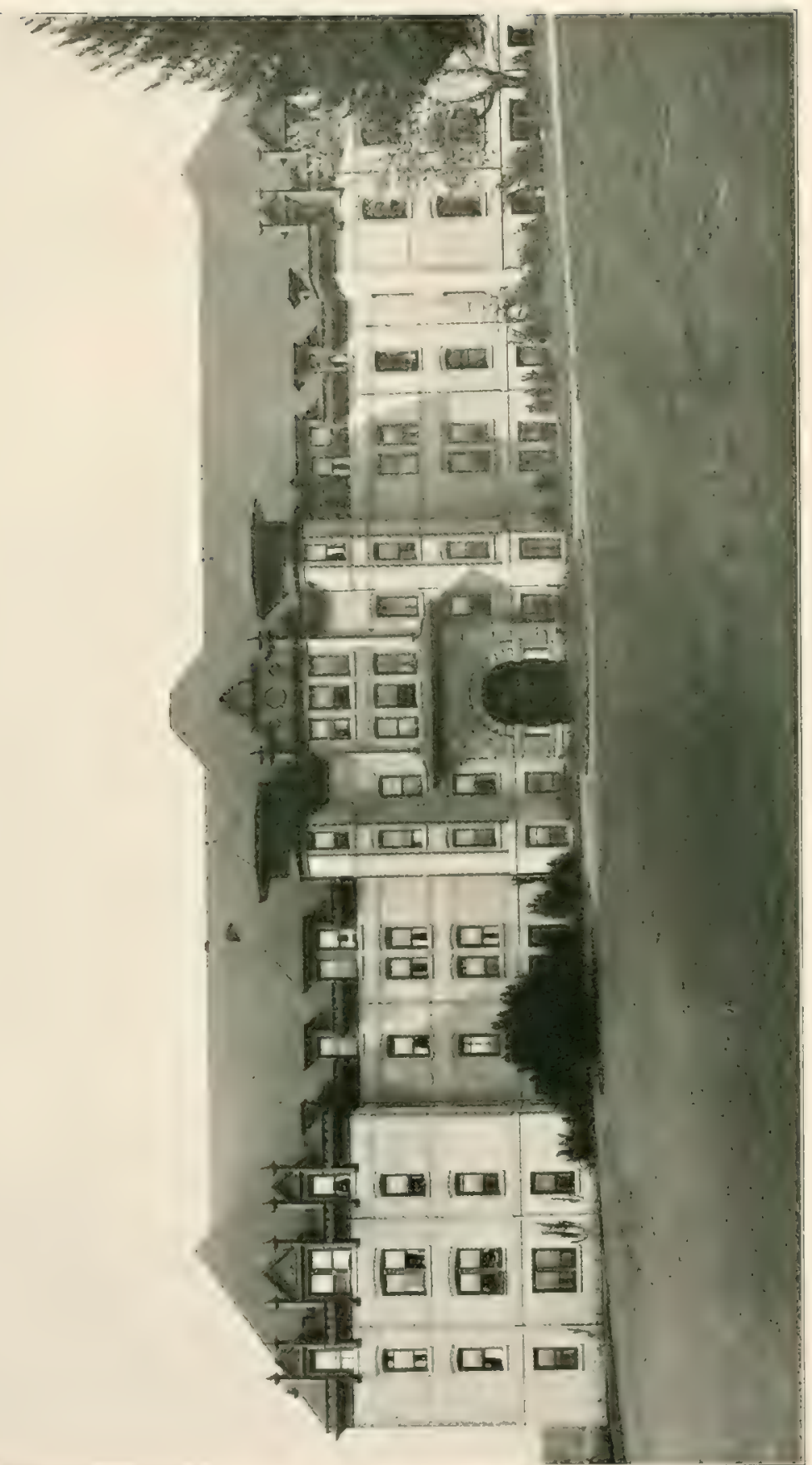

ह 


\section{SCHOOL OF MINES.}

Oregon's mineral industries are still in their infancy. They await the leaders who can guide them into a competent and aggressive independence. States that border Oregon are rich in mineral products: Washington to the north, Idaho to the east, and California to the south, all have had, and still enjoy, a versatile and abundant mineral wealth. Oregon's geological conditions are identical in most essentials with those of her neighbors. Corresponding riches, under corresponding methods of development, should naturally follow.

Until recent years, however, lack of authoritative information concerning mineral resources in Oregon has given her but one-fourth the $\$ 17,000,000$ worth of mineral products that Washington has turned out, and but one-twentieth of the $\$ 86,000,000$ worth of minerals that California has produced. Under the encouragement of scientific data, however, the worth of the metals produeed in Oregon has increased during the past two years one hundred and sixty per cent. The School of Mines of the Agricultural College, in cooperation with the Oregon Bureau of Mines, has shown conclusively that while $\$ 135,000,000$ worth of gold and silver has been recovered from Oregon's mines, yet there are extensive and altogether promising areas where little prospecting and no development work has yet been undertaken. Thus it seems probable that Oregon's harvest of these precious metals is only at its beginning.

Many other minerals, not a few of them of first importance for commercial and structural purposes, are found in abundance in different sections of Oregon. Limestone and shale, suitalle for the manufacture of cement and quicklime are plentiful in several localities; clays of all kinds and qualities are widely distributed; building and ornamental stones of many varieties and of choice quality have been located in different parts of the State; coal, chromite, copper, lead, zine, iron, and asbestos are still other minerals that exist, in more or less promising quantities, in the State, while the nickel deposits near Riddle give promise of being the most important in the United-States.

This is a remarkable mineral endowment. Yet in the face of such native wealth, oregon imports annually millions of dollars worth of geological products, at least three-fourths of which could be profitably produced within her own borders. To remedy this unfortunate commercial condition, is one of the leading objects of the school of Mines. Not only hy making authentic surveys of the State's geological resourees, conducted chiefly through the Oregon Bureau of Mines, but also by turning out competently trained men who appreciate Oregon's opportunity in the field of mining and ceramies, and are able to lead the way in the intelligent exploitation of this field, the School of Mines is making splendid progress. 

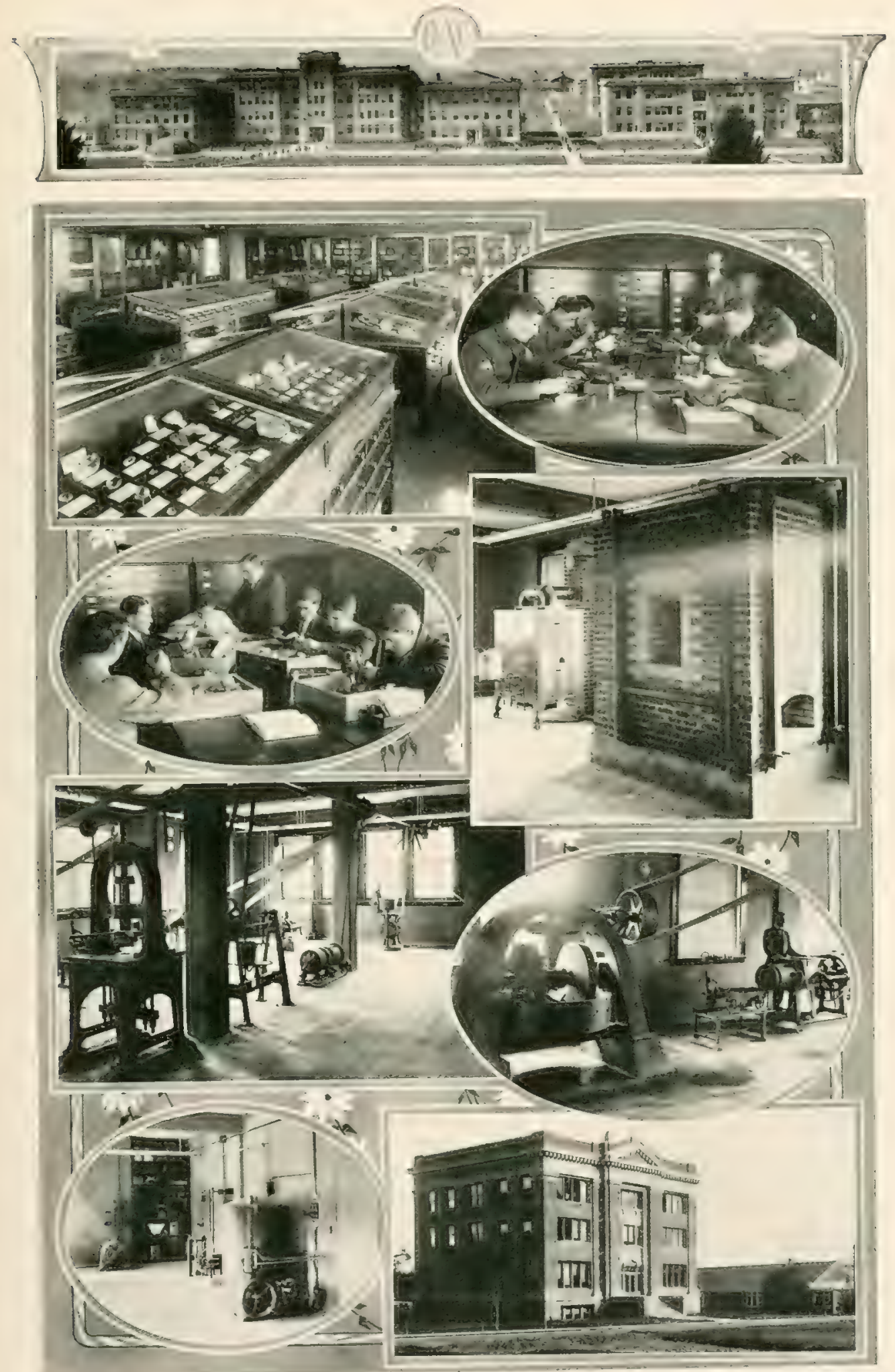

MINES

SHOWING THE MUSEUM, WITH GLIMPSES OF THE LABORATORIES IN GEOLOGY, CERAMICS, AND ORE DRESSING 


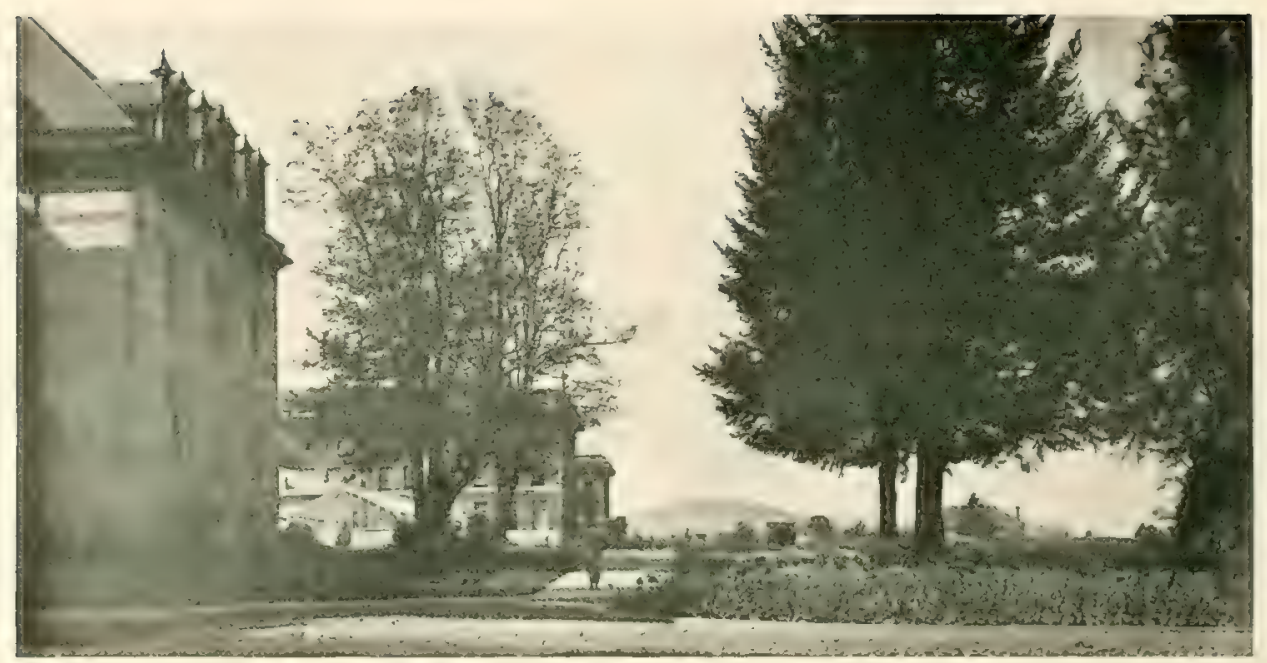

A GIIMPSE FROM WALDO HALL LOOKING NOITH

Its ultimate success in this eampaign will mean the flow of a rich revenue through the commercial arteries of the State, not for a decade only, but for all time. Those who take part in this vast plan of development will perform an enduring service for the State. They must be trained men, with knowledge and skill to afford intelligent leadership; and they must be men of vision, who will not let the petty discouragements of an hour obscure the goal of splendid achievement that the future has in store. Their program, which is not for a day, is identical with that of the College-to make detailed and comprehensive surveys of the mineral resources of the State; to determine the fitness of the respective minerals for use in the business of the commonwealth; to indicate the probable extent to which these minerals may be macle profitably arailable through practicalble means of mining or manufacture; and to mike known the fundamentals of the sciences and engineering practices necessary for the suceessful prosecution of the great mining and ceramic industries.

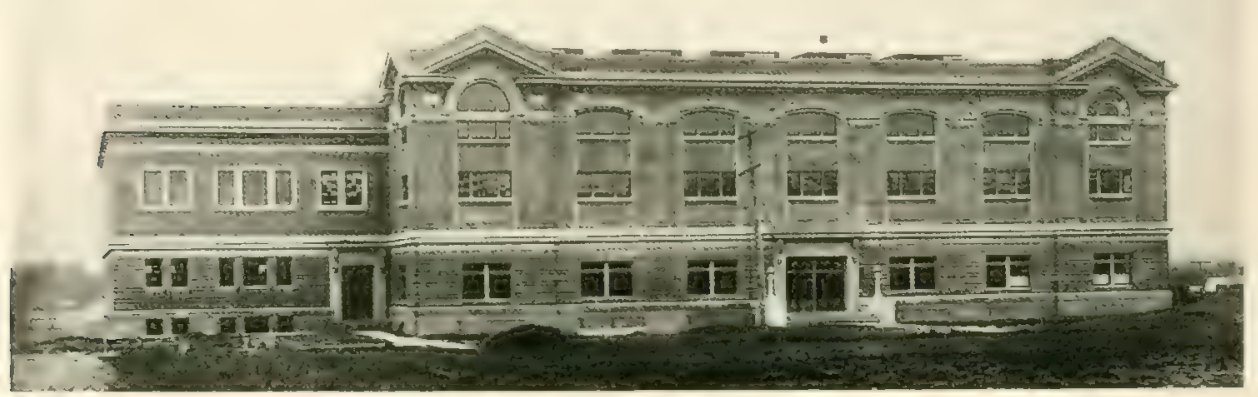

THE: NEW MEN'S GYMNASIUM (INCOMPLETE) 

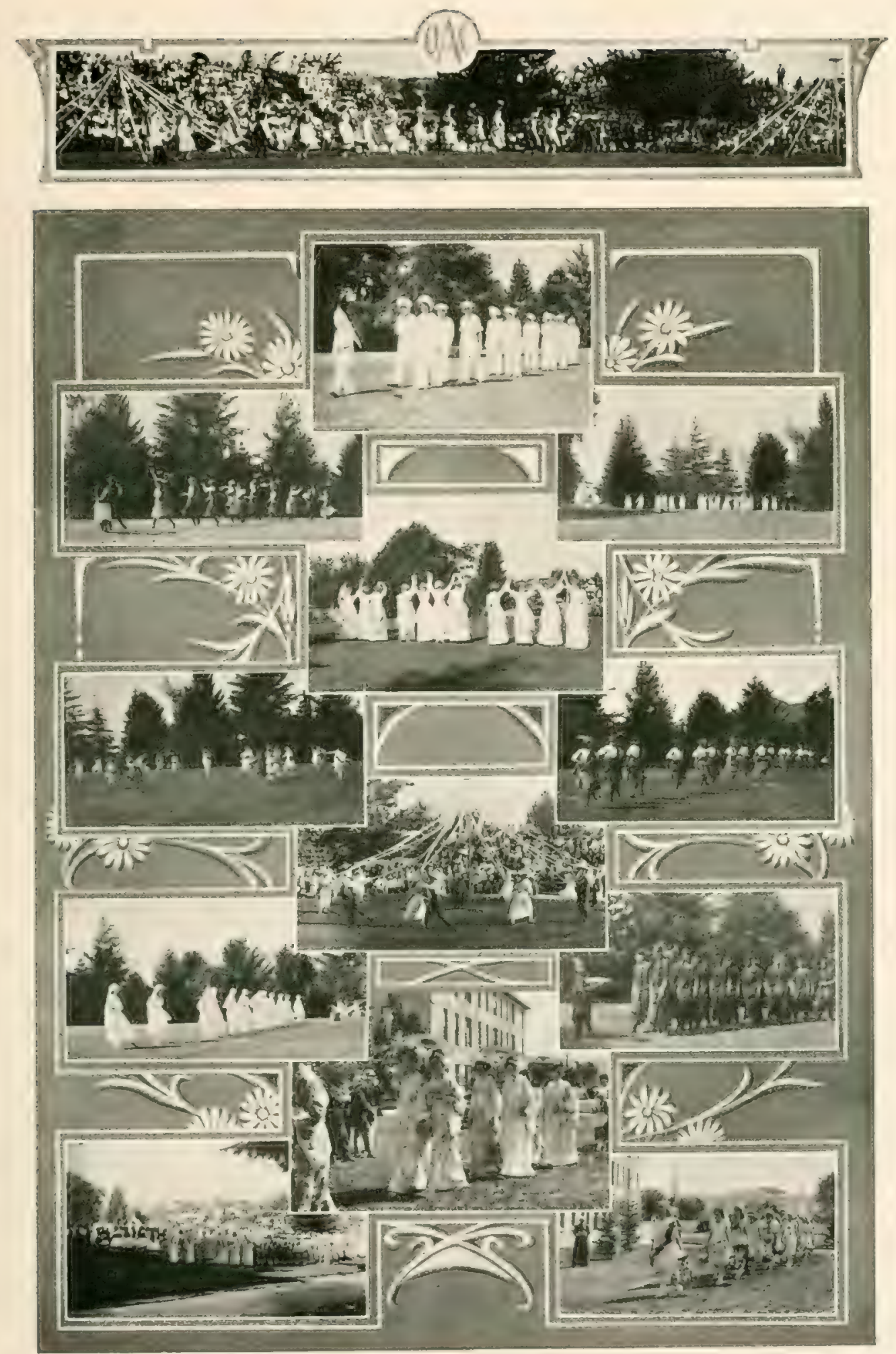


\section{SCHOOL OF HOME ECONOMICS.}

The School of Home Economics in the Oregon Agricultural College is one of the most important factors in the organization of the institution. Its growth has been phenomenal, its enrollment for the present year being second only to that of the School of Agriculture. Its activities, both in resident instruction and in extension service, have developed as rapidly as its enrollment. In spite of heavy class and laboratory duties, as well as excessive obligations incident to student organizations and institutional events, the members of the faculty have engaged in important researeh and investigational work, and have directed the studies of advanced students in this important field. The attituaie of the administrative authorities of the school toward this work is well shown by the report of the Dean of the School of Home Economies for the year 1914-15, which says: "It is eminently fitting that the School of Home Economics carry out a series of experiments relating to home problems. So little actual information exists concerning household matters that a great fiela is open to some institution to establish a department of household experimental work and to publish the results of their investigations."

Only the briefest outline of the investigational work of the school can be offered here. Even the mention of some of the efforts that have been launched, however, will show the significance of the work. Exhaustive studies relating to the cooking qualities of various Oregon apples at different seasons of the year have been carried out, and the result published in bulletin form.* Studies relating to pears and also to the uses of loganberries have been oceupying the attention of graduate students. A coure in experimental cookery, which has enrolled twelve senior students, has directed the work of investigating various individual short problems. Thus, experiments have been made on the cooking qualities of the leading varieties of potatoes raised on arid, irrigated, and valley lands. Other experiments have sought to determine the comparative value of spring salmon and fall salmon in various cooked products. Still other experiments aim to determine the value for home and institutional use of various meals now on the market, such as pea, bean, and lentil meals, which give promise of general usefulness; and the comparative value of eggs of different degrees of freshness, as well as eggs preserved in water glass and in various other ways, for the making of such delicate egg products as mayonnaise.

Domestic Art problems, such as the different methods of finishing woods for house interiors, and the various color schemes possible for interior finish with the western woods commonly used in interior house construction, have also occupied the attention of advanced students in Home Economics.

-Station Bulletin 124. 

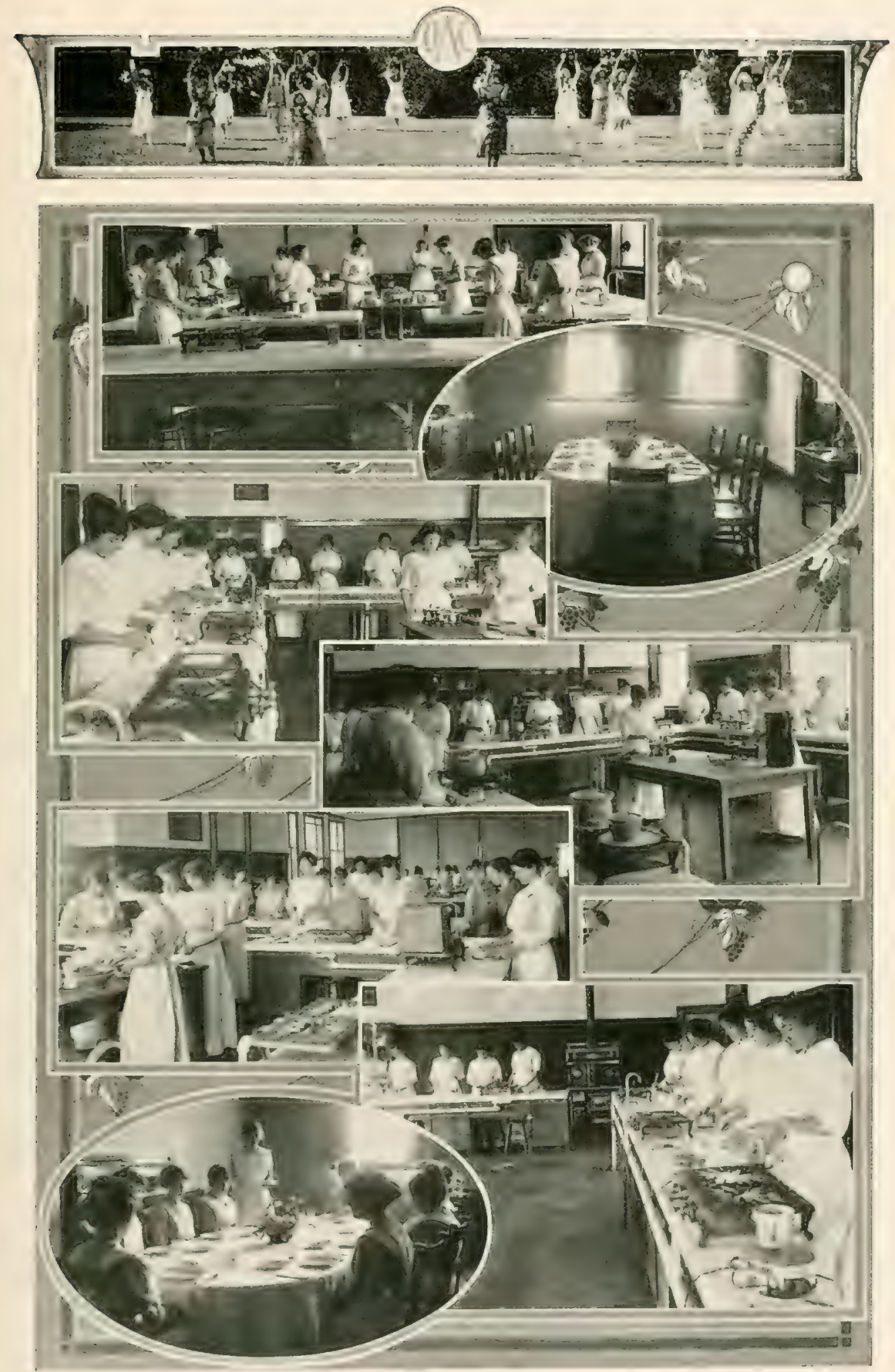

DOMESTIC SCIENCF 
Plans are made, and are being carried out as rapicily as the time and the resources of the school permit, for experiments with the common Oregon fuels, to determine their comparative economy and efficiency; for testing the various "labor-saving" devices for the household, and for a variety of investigational studies concerning the science and art of home-making and institutional management.

Not the least of the school's efforts in opening up new avenues for home betterment, for community progress, and for civic righteousness, are its extension services throughout the State-its personal contact with parent-teachers' associations, community centers, civic improvement leagues, women's clubs, granges, and various other organizations designed to blaze a trail to a larger, more fraternal, and more spiritualized private and public life.

\section{MILITARY DEPARTMENT.}

The Military organization of the College consists of one regiment of infantry having three battalions of four companies each. It includes also a hospital corps, a signal corps detachment, and a double band of fifty pieces. The organization is mantained at the behest of the United States Government, which delegates an officer of the United States Army, with two assistants, to direct the work as Commandant. The eight hundred men enrolled in the organization receive, in the course of their military training, a very superior type of discipline: which not only improves their personal bearing and helps to cultivate habits of restraint, decision, and alertness; but improves their health as well.

The Regiment has repeatedly taken high rank in the official reports concerning the cadet regiments of the land-grant colleges throughout the country, and has been a source of congratulation to the College on all occasions.

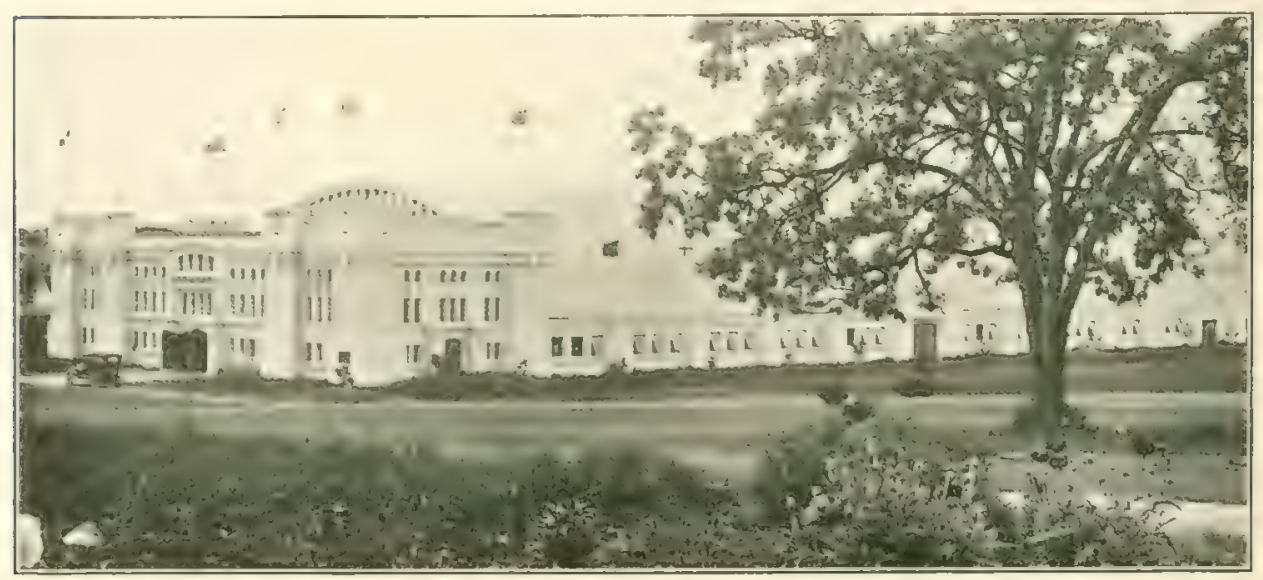

THF ARMORY 

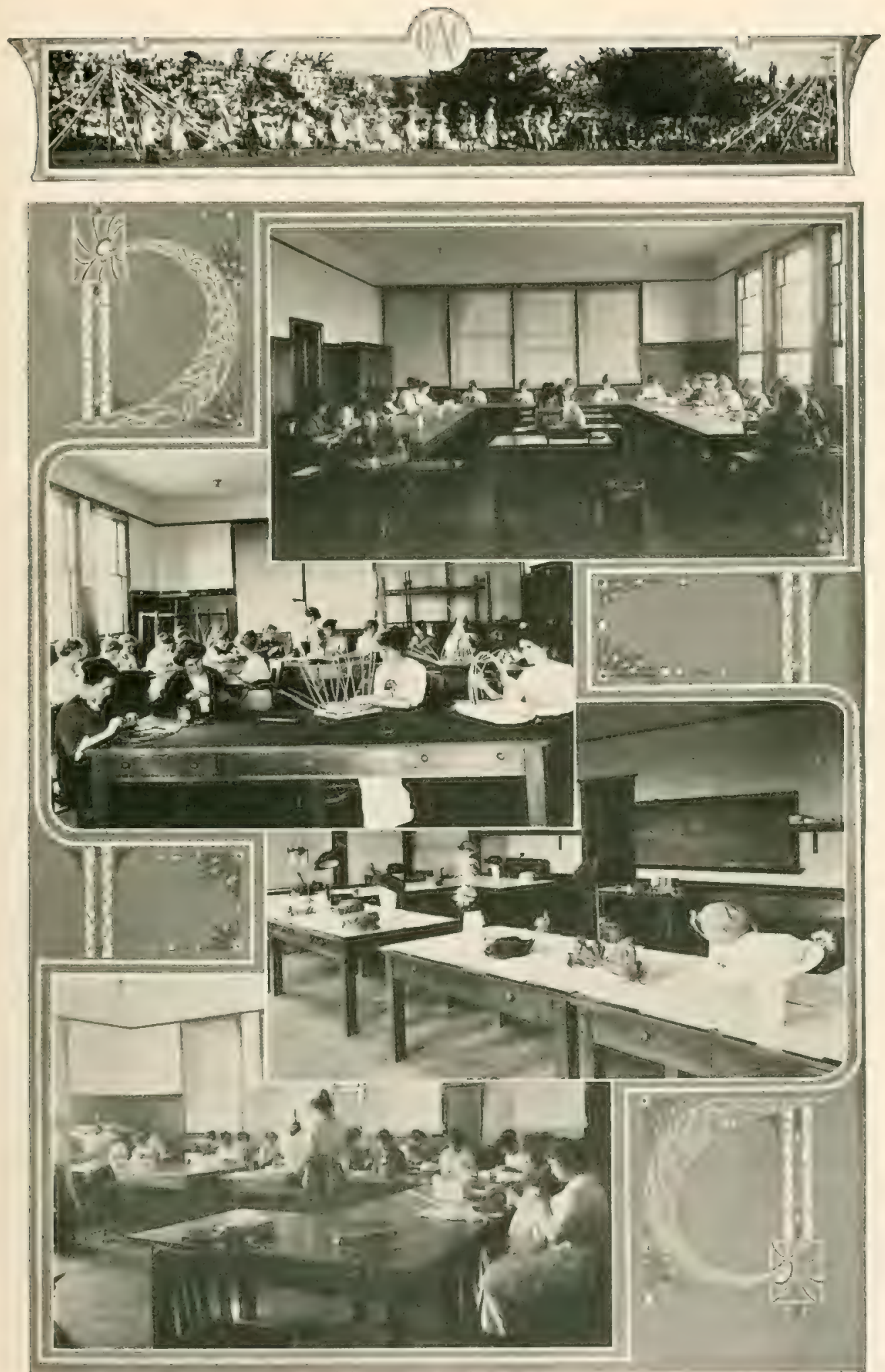

DOMESTIC ART

VIFWS OF THE SFWING, BASKETRY, AND DRESSMAKING LABORATORIES, TO(HTHER WITH AN EXUIRIT OF MILLINERY MADF BY A 1914 CLASE 


\section{SCHOOL OF COMMERGE.}

'The School of Commerce, which is ranked among the few best in the country, has been a national leader in evolving systems of farm accounts, farm records, and various devices for insuring a simple and accurate method of determining

\section{Pioneering the} New Agriculture. the net profit of farm operations, and the expense of household maintenance.* It has been a leader also in the campaign for improved methods of marketing farm products, maintaining that the most acute defect in the machinery of agricultural operations today is the loss of value in transferring products from producers to consumers, or the diversion of profits to those among the handlers of these products who have not earned them. Accordingly, it has taken the initiative, at the request of the farmers, in the organization of various cooperative associations throughout the State, some of which have already made conspicuous suceesses in the conduct of their affairs. It has also interested itself in the various systems of community organization that make for greater efficiency in business, in social relations, and in the betterment of the rural home.* Noting the successful examples of these modern movements in various European countries that have enriched themselves through a progressive agriculture, it has adapted these methods to local conditions and made its recommendations accordingly.

Rural credit, that gives to the farmer such privileges as the business man of the city commonly enjoys at the hamds of his local hanks, especially cooperative credit associations, rural insurance, and equitable methods of taxing farm propAnd the New Search for Efficiency. erties, are still others of the paramount problems that are engaging the attention of the School of Commerce. Through the Bureau of statisties, one of the departments of the School, a vast amount of important data is being accumulated, and classified, which is proving to be an ever-increasing asset in the study of the economic problems of the Pacific Northwest. Rural Law, still another subject of vital importance to the average citizen of Oregon, has been given merited attention at the hands of the School of Commerce, which has recently issued a summary of its important principles in bulletin form. $\dagger$ Aside from this pioneering attack upon the great rural problems, the School is also enlisted in the present-day movement for efficiency in the conduct of all types of business - through attention to the big human problems involved, as well as to the details of office equipment, filing devices, etc., that make for economy and for power.

- College Bulletin 33

- College Bulletin 71

tCollege Bulletin 196 

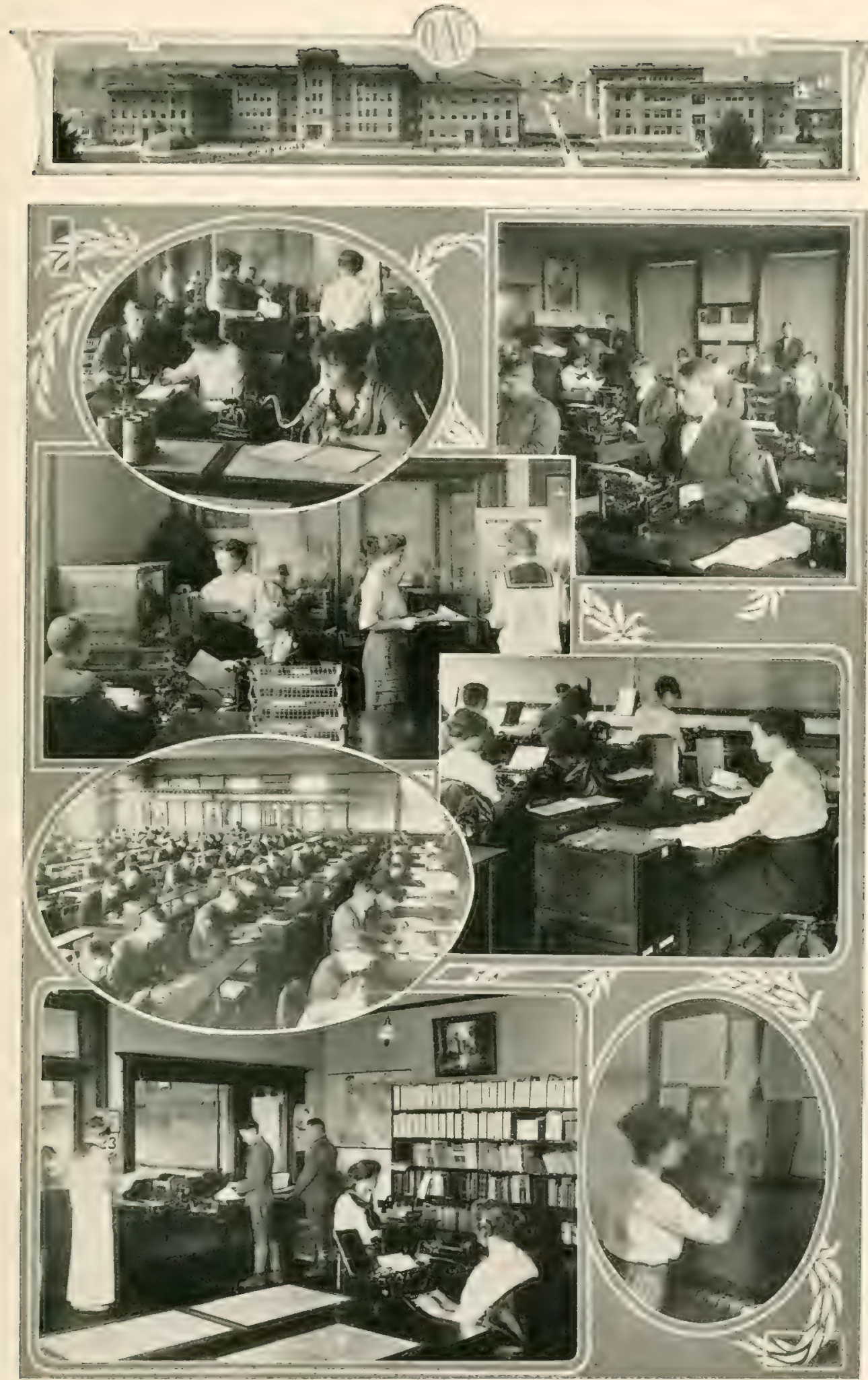

COMMERCE

SHOWING VARIOUS ACTIVTIES IN THE BUSY DEPARTMENTS OF THIS EFFICIENT SCHOOL 


\section{PHARMACY.}

The more exacting standards regarding the licensing of physicians, pharmacists, and ascistant pharmacists, the new demand for pure food and drugs. and the consequent warfare on adulterants, have given new importance to wellcquipped schook of phamaley and imposed upon them additional responsibilities. A school of pharmacy located in a state agricultural college and having access to its extensive facilities for investigation and instruction in chemistry, bacteriology, zoology, botany and other allied subjects, has many advantages over an independent school, however adequately equipped in other respects. Through contact with the energizing and broadening influences of other departments charged with important functions hy both state and Nation, it takes on an added dignity and a more penetrating method of work.

Under the new administration of the department, improved organization has increased its efficiency and added new courses of instruction. A sustained effort is being made, moreover, not only to equip students of all courses in the department to meet the responsibilities which the law exacts of them, but to become exponents of the highest ideals and the most exacting attainments of the profession. Steps have been taken, also, to utilize the peculiar opportunities offered by an experiment station by establishing a drug garden for the experimental culture of various native and acclimated drug plants.

A two-years course, designed especially to meet the requirements of the American Conference of Pharmaceutical Faculties, and leading to the degree of Ph. G. (graduate in pharmacy), has reenty leen added to the regular long courses leading to the baccalaureate degree. Never before has the department been so competently qualified to exercise a useful influence and a constructive leadership in the pharmaceutical profession of the Pacific Northwest.

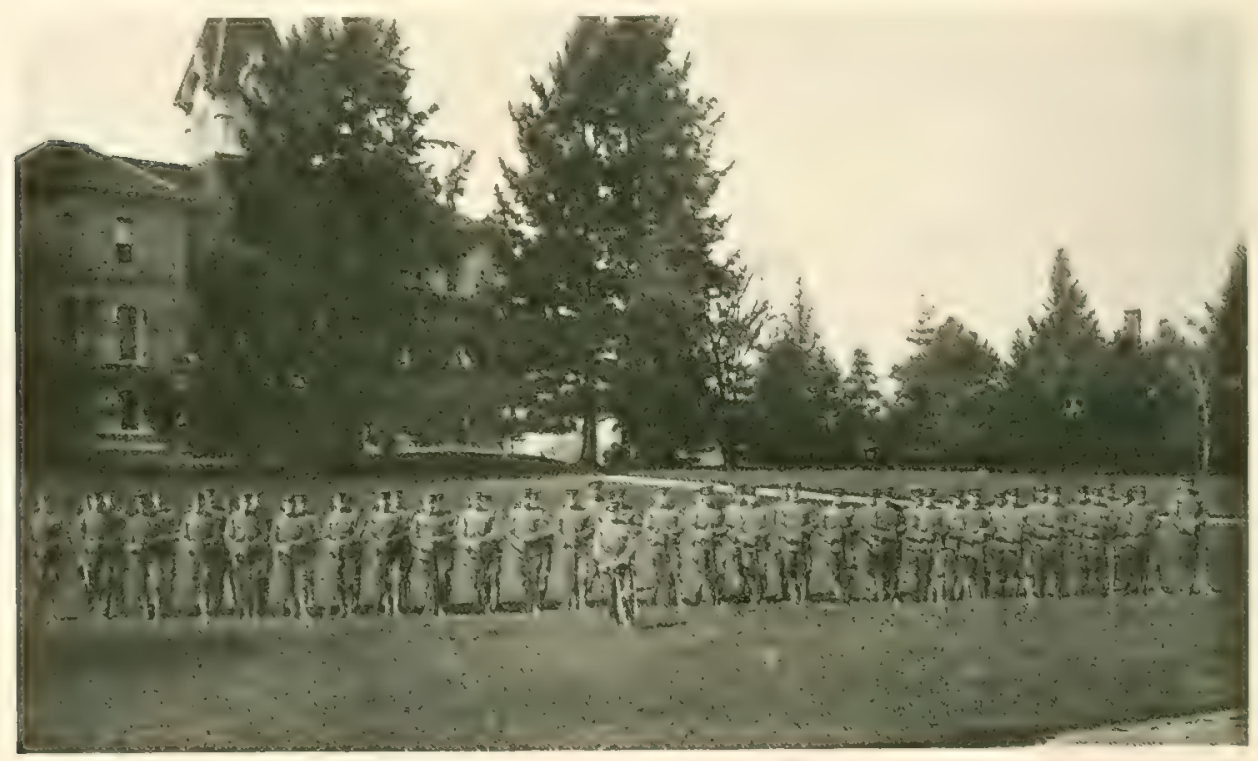



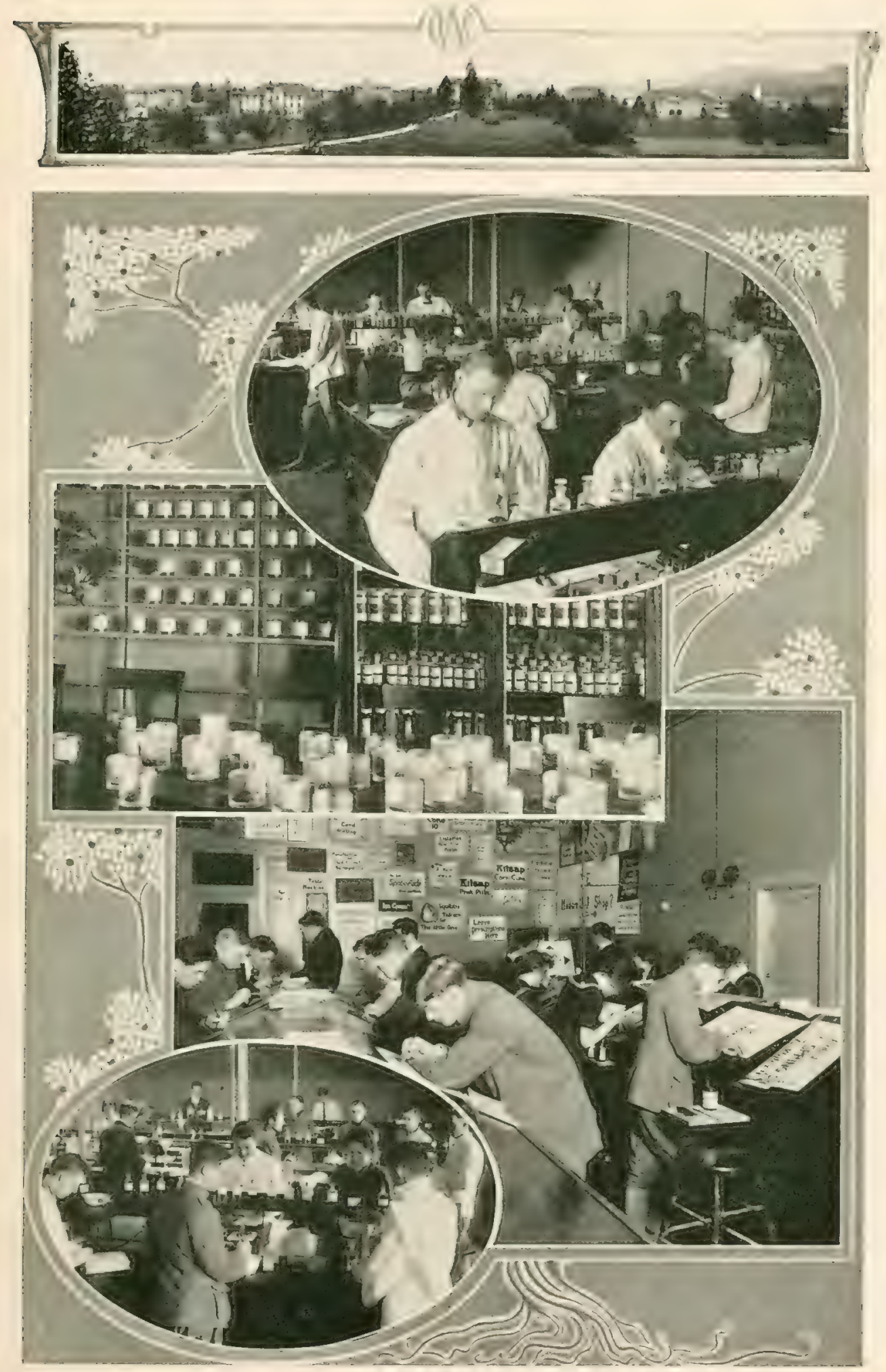

PHARMACY

SHOWING LABORATORIES AND SIGN-PAINTING ROON 


\section{THE EXTENSION SERVICE.}

The Extension Service of the College is the newest of its three grand divisions of work; namely, Investigation, Instruction, and Extension. Investigation, which includes all work of the Experiment Station, is essentially a search for fundamental truth: it is the foundation work without which

Objects of Extension Service. the other two grand divisions would soon become sterile and ineffective. Instruction, which includes all work of teaching students at the institution, is the most conspicuous and distinctive feature of the College life; it gives motive and vitality to the investigational work, and transmits it not only to the present but to the future. Extension Service, which includes all means of imparting the message of the College to the people in their own communities, is virtually a sowing broadcast throughout the State of the available truths worked out hy the Experiment station or found applicable for resident instruction. It aims to benefit the many, rather than the few, and to make practical and immediate application of the great hody of seientific knowledge that only awaits the right means of circulation to work a revolution in the agricultural and industrial welfare of the State.

The Extension Service at the Oregon Agricultural college, like that in similar institutions of other states, has advanced by giant strides. Four years ago it was a hopeful plan. Today it is a convincing reality, with a force of thirty-two aggressive workers, devoting their full time to its program,

Its Rapid

Growth. and with scores of assistants in the persons of Station and College officers and instructors. Through its itinerant schools, devoted to dairying, horticulture, agronomy, animal husbandry, and home economics; and through its institutes, short courses, and community and individual demonstrations, it has reached every county in ()regon during the past year, and has responded to calls from every community that was in position to profit by its services. Over one hundred thousand people have been reached by its various modes of instruction.

The Industrial Club work of the public schools, one of the most constructive features of the Extension Service, fraught with the utmost promise for the future, has included projects in gardening, poultry-raising, stock-raising, cooking, canning, sewing, etc., that have enlisted the ardent energies of Industrial Club Work. 12,000 boys and girls, all taking suggestions from the Industrial Club Leader of the Extension Service, and most of them sending to him, at the conclusion of their work, a detailed and informing report concerning the progress of their projects. 

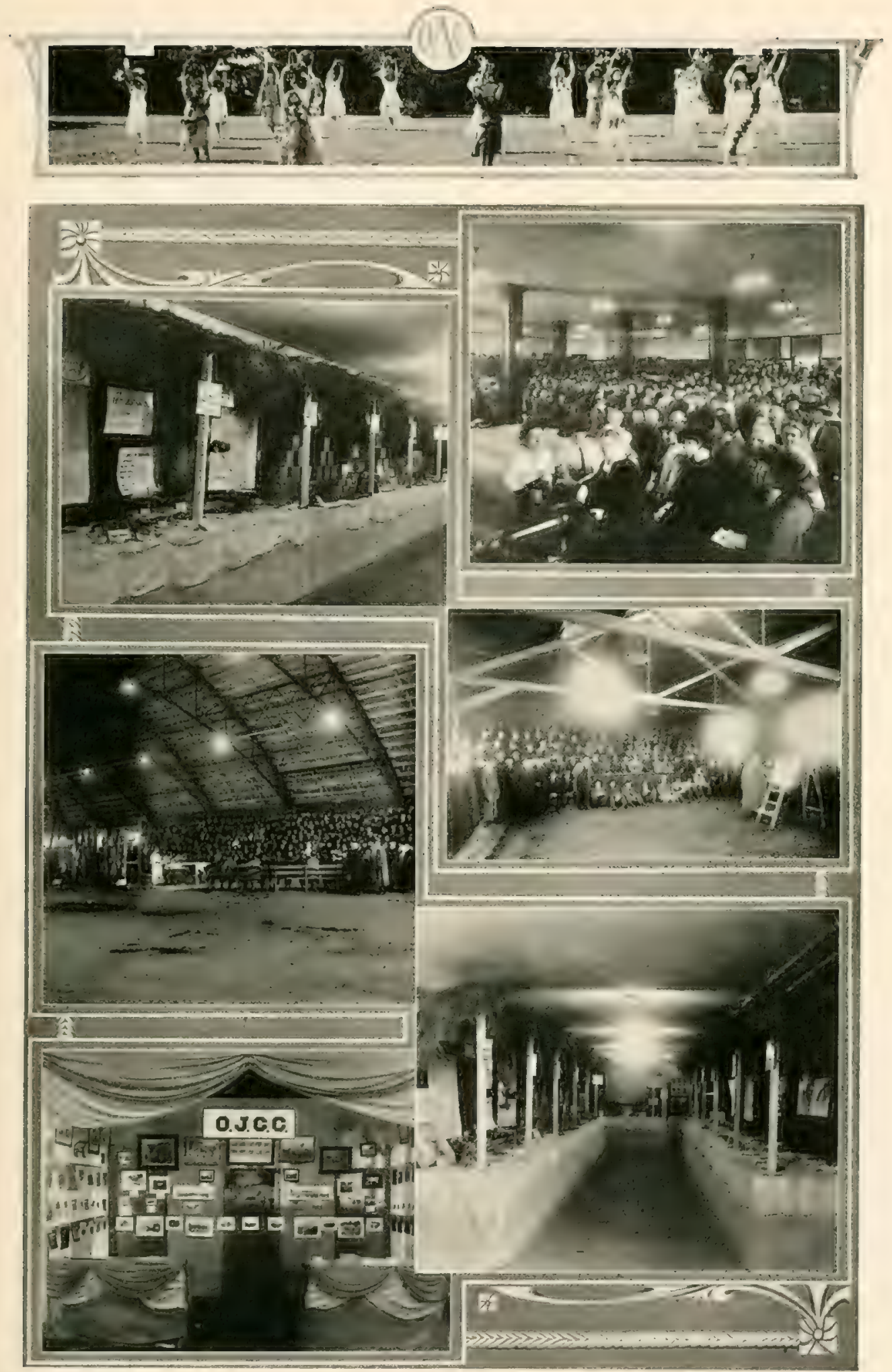
The county agricultural work, a form of extension service in which the State of Oregon has taken an advanced position among the states of the Union, has made remarkable progress since its inauguration in 1914. Thirteen counties

The County Agents. have already taken the necessary legal steps to enroll in the movement, and have employed county agents to conduct this momentous work. Men employed for this service require both expert training in a technical college and practical experience in farm work. Such men are diligently sought out by the authorities responsible for this work and where they are secured, the county agricultural plan works wonders in uniting the farmers for better agricultural practices, and for a larger, more aggressive, and more prosperous community life.

At the beginning of the present year, in cooperation with the United States Department of Agriculture, the Extension Service employed a man to undertake a Farm Management Survey of the State. He selects groups of about sixty farms, representing conditions typical of various sections of

Farm Management Survey.

the State. Conditions on these farms are analyzed in detail to determine the net labor income of the various individual farms and to determine esperially what operations are profitable and what are not. Upon the completion of the survey, the information will be taken back to the farmers, and analyzed with a view to showing how unprofitable operations may be corrected.

In these and many other ways, increasingly practical, direct, and intimate, the Extension service is taking to the people the benefits of the scientific information that centers in the College, and is bringing back from this contact an energizing contribution from a practical and progressive con-

The Mutual Benefits. stituency. Just here springs a benefit from the Extension Service that is rarely if ever emphasized-the responsive influence of the community that is reached; the recoil, so to speak, resulting from the personal contact of representatives of the State Institution and representatives of an alert, searching, and aspiring public. In this sense, the Extension Service is the lungs of the College organism, vitalizing its circulation, reporting the pulse of its constituency, safeguarding it from a cloistered isolation, and stimulating it to a keen, competent, and practical service to the commonwealth. 

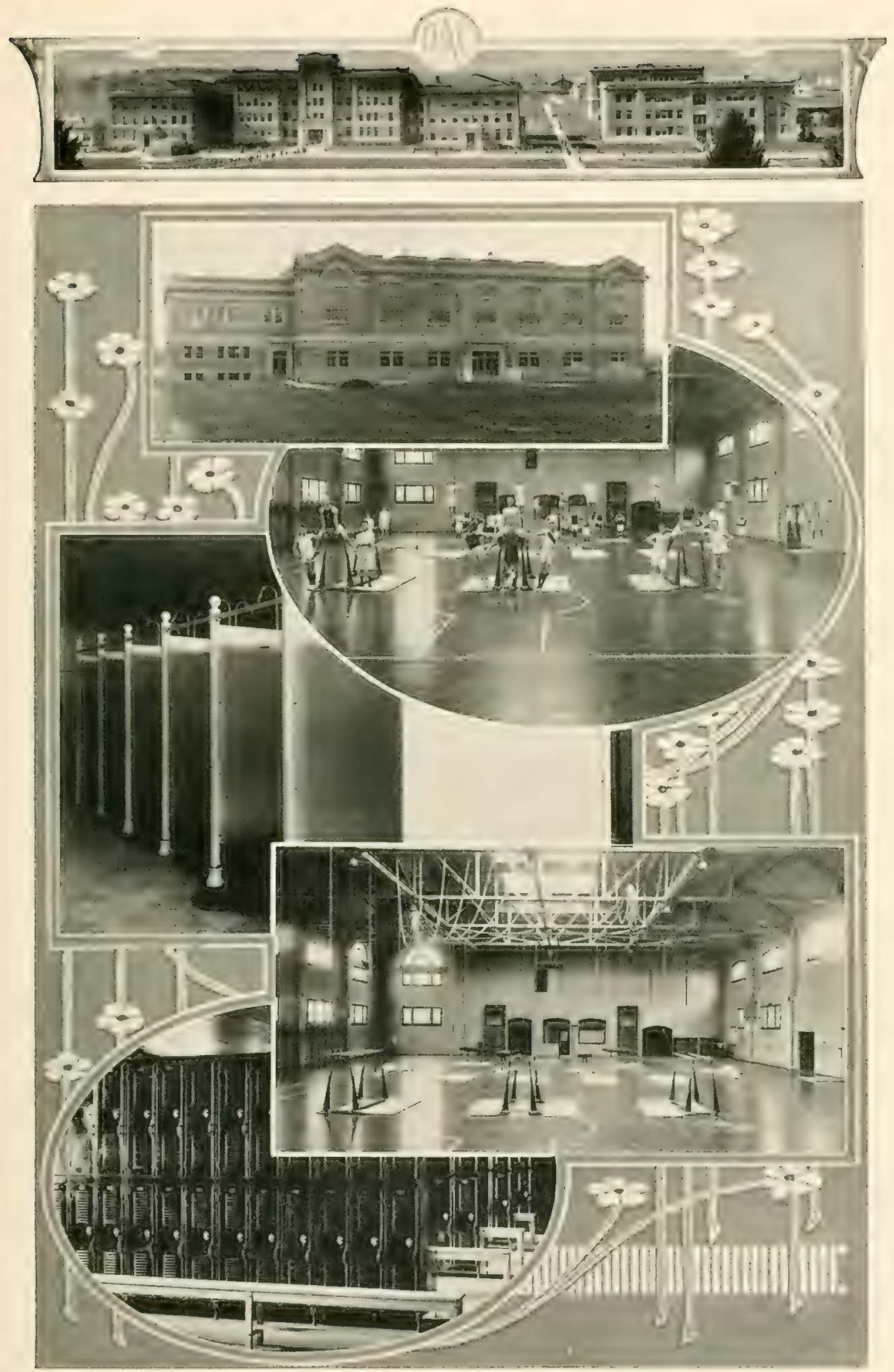

PHYSICAI, EDUCATION

SOME OF THE FACILITIES FOR PHYSICAL EDUCATION FOIR MEN 


\section{PHYSICAL EDUCATION.}

Physical Education, including athletics, both for men and for women, is under faculty direction at the Oregon Agricultural College, where it is a regular factor in the courses of study required of all for graduation. In this respect the College is in the vanguard of those institutions of higher learning throughout the country that are giving serious, constructive attention to the health and physical development of their students. Professionally trained faculties have charge of physical education and athletic sports for men and for women, respectively, with separate and specially equipped gymnasiums. The system of training recently instituted at the College, especially in corrective and medical gymnastics, has excited very general approval, wherever it has come to the attention of the authorities of similar institutions. Its constructive effects are already manifested, and will continue to grow, with cumulative results, as time gives opportunity. Its purpose is to give to every student, through the most wholesome and spontaneous activities that are possible in the given case, such training as will develop a symmetrical and self-sustaining physique.

Investigation, resident instruction, extension-these are the three grand divisions of work at the Oregon Agricultural College. This booklet has been chiefly concerned with investigation-research, experimentation, and original inquiry. This is not, by any means, the sum of the institution's service to the State. It is but a fraction of that service. Not all departments of the College are represented here, or even mentioned. Those only that are chiefly concerned with investigative or experimental work-and that of an economic nature-are dealt with. What may be said here, what may be omitted here, is in no sense prejudicial to departments not treated. They are as valuable a part, in other ways, of a great educational institution, armirably fulfilling its high function, its various members working smoothly together in articulate harmony, its policy and ideals-manifested through the work of the various schools, and unified by a central genius of administration working steadily toward a splendid solidarity. The Oregon Agricultural College aims to give its students not simply the best type of technical instruction that the land-grant colleges afford, but a "liberal and practical education.... in the several pursuits and professions in life." 

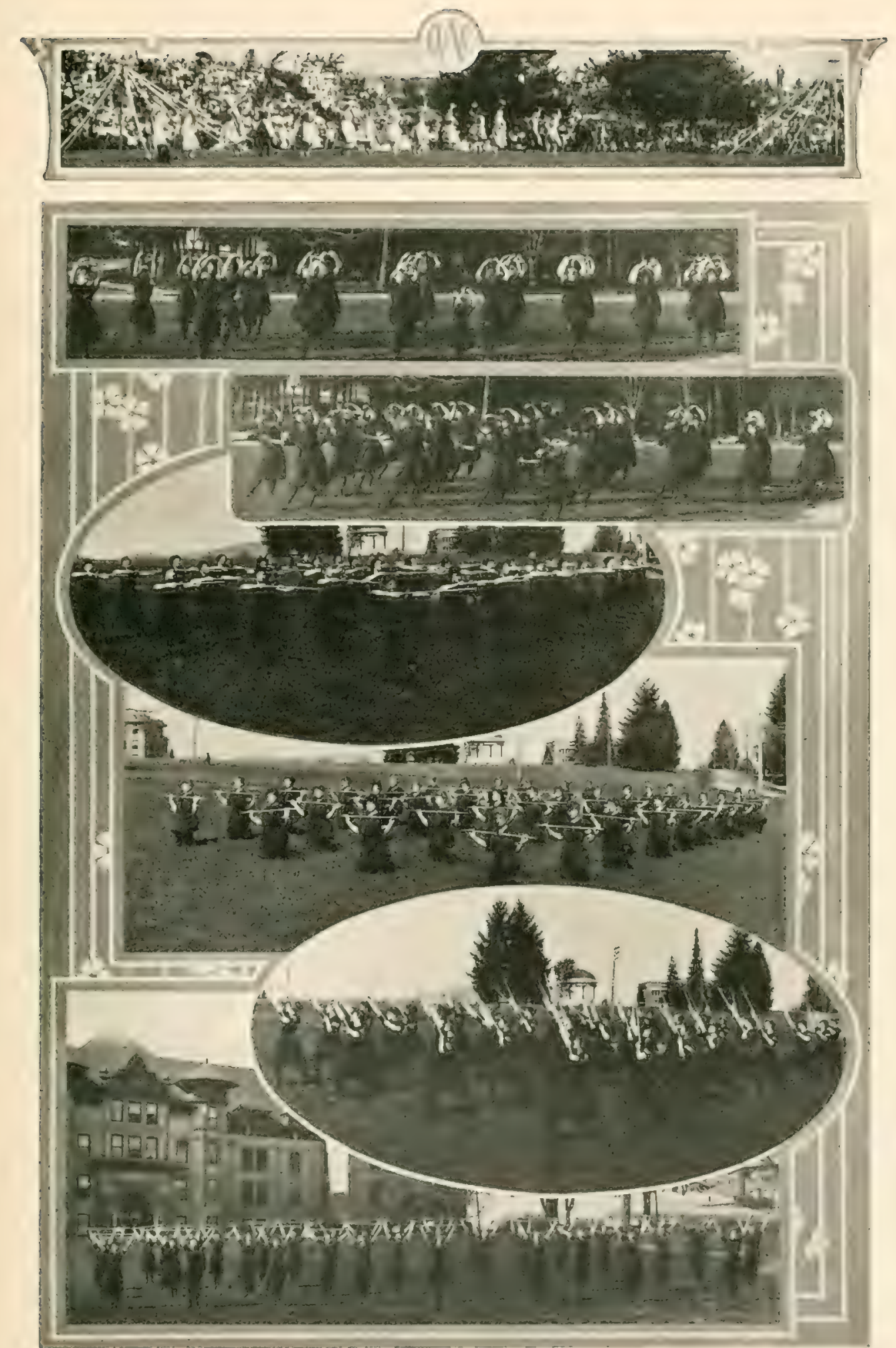

PHYSICAL EDUCATION

FORMAL UUTDOOR FXERCISES IN PHYSICAL EDUCATIOS FOR WOMEN 


\section{FACTS ABOUT THE OREGON AGRICULTURAL COLLEGE.}

\section{Founded in 1885 .}

Student Publications include The Barometer, issued semi-weekly, The Oregon Countryman and The Student Engineer, issued monthly, The C.-P. Journal, issued quarterly, and the Junior Annual.

Presidents. The College has been fortunate in having few changes in the presidency, especially in recent years. D. I. Arnold occupied the office from the establishment of the College as a State institution up to $1892 ; J$. M. Bloss from ' 92 to '96; H. B. Miller from '96 to '97; Thomas M. Gatch from '97 to 1907, and Villiam Jasper Kerr from 1907 to the present time.

Faculty and Employees. 'The faculty comprises six deans, 31 professors, 8 associate professors, 21 assistant professors, 69 instructors, and 23 assistants, besides one hundred and fifteen other persons variously employed in instruction, extension, and experimental work.

Enrollment. The total enrollment in all courses for 1914-15, to March 6, is 4,158. Of these, 2,598 are men, 1,560 are women; 2,535 are enrolled in the summer and winter short courses, 1,623 in the regular thirty-six weeks' courses. The schools of Agriculture and Home Economics lead all the schools of the College in enrollment, the school of Engineering ranking third, Commerce fourth.

Buildings and Equipment. Fifteen substantial buildings of brick and stone with five additional frame buildings, comprise the campus group used for instructional and laboratory purposes. In addition, two large dormitories for women, both of which are modern and attractive, and a dozen or more farm and service buildings are utilized in carrying on the work of the College and Expermient Station.

'The equipment throughout the institution is sterling and efficient; representing excellent values for the money invested. Since many of the schools have been established within the past decade, their entire resources are of the most modern and approved type. The Schools of Agriculture, Commerce, Mining, and Home Economics, for instance, are cquipped to compete with the best of the land-grant colleges, while the school of Engineering has no superior in the West.

Environment. The environment of the College, both natural and civic, is ideal. The institution is located at Corvallis, in "the heart of the valley," with excelleat transportation facilities over a half-dozen railroads and a steamboat line on the Willamette river. The city itself, which has a population of 6,000 , is one of the most beautiful in the State, with a civic life altogether alert, wholesome, and attractive. Its citizens take a great interest in the College and appreciate their responsibilities as a factor in educating the youtbs of the Pacific Northwest.

Student Life. Student self-government has prevailed successfully for four years. Practically two-thirds of all the students are wholly or partly self-supporting. The men live principally in clubs, the women in two substantial College dormitories, attractively situated on the campus. Social life is ample, yet properly restrained, and College interests manifest a wholesome enthusiasm for the vocations as well as the avocations of real life. Leadership is thus developed through student activities as well as through regular college instruction.

Living expenses are moderate, the necessary outlay of the wverage student in College being about $\$ 220$ a college year.

Opportunities for Graduates. In no field today are the opportunities for graduates so numerous and attractive as in the fields for which men and women are prepared at the Oregon Agricultural College. Agricultural and industrial education are every year demanding more competent workers than ever before. The agricultural and mechanical industries are waiting for scientifically trained men. Forestry and mining are dynamic and almost virgin fields for skilled workers in Oregon, which is one of the richest States for these vocations in America. Students, either men or women, competently trained in Commerce or Pharmacy, find ready and profitable fields of usefulness, while the young woman equipped with the substantial type of education offered in the School of Home Economies, is qualified for leadership in many walks of life.

The school of Music, affiliated with the College, offers instruction in voice, piano, violin, orchestra, and band. 


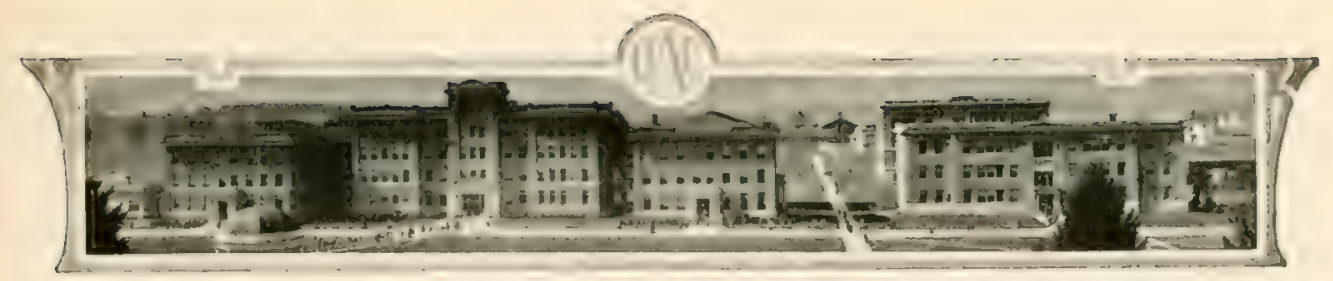

THE STUDENT'S OPPORTUNITY.

Students of a land-grant college of today-the college where scientific researeh, investigation, and experimentation are carried on side by side with resident instruction and with extension-become the trail blazers of tomorrow. They learn to lead. They are self-supporting because their education is practical; they acquire initiative and a democratic spirit because of the ideals of the land-grant college, which is backed by the State and the Nation.

THE OREGON AGRICULTURAI. COLLEGE is one of the learling land-grant colleges of the country. It is the largest institution of higher learning in Oregon. It comprisessix schools of instruction, with 26 subdivisions, offering degrees. Entrance to these regular four-years degree courses requires a standard high school course of study as preparation. Entrance to the vocational courses requires an eighth grade preparation, or equivalent practical experience on the part of mature applicants.

Following are the Courses of Study leading to degrees:

In the SCHOOL OF AGRICULTURE, major courses in-
(a) General Agriculture
(g) Agricultural Chemistry
(b) Agronomy
(h) Agricultural Bacteriology
(c) Animal Husbandry
(i) Botany and Plant Pathology
(d) Dairy Husbandry
(e) Horticulture
(j) Economic Entomology
(f) Poultry Husbandry
(k) Economic Zoology
(1) Agricultural Education

In the SCHOOL OF FORESTRY, major courses in-
(a) General Forestry
(b) Logging Engineering

In the SCHOOL OF HOME ECONOMICS, major courses in-
(a) Domestic Science
(c) Home Administration
(b) Domestic Art
(d) Institutional Management

In the SCHOOL OF ENGINEERING, major courses in-
(a) *Civil Engineering
(b) Electrical Engineering
(d) Highway Engineering
(c) Mechanical Engineering
(e) Irrigation Engineering
(f) Industrial Arts

In the SCHOOL OF MINES, major courses in-
(a) Mining Engineering
(c) Chemical Engineering
(b) Ceramic Engineering

In the SCHOOL OF COMMERCE, a major course in-

(a) Commerce

In the department of PHARMACY, a course in-

(a) Pharmacy

In addition to the above haccalaureate courses, provision has been made for the following VOCATIONAL COURSES:

A. Agriculture (one year)

B. Dairying (one year)

C. Home Makers' Course (one year)

D. Mechanic Arts (three years)

E. Forestry (November 2 to April 16)

F. Business Short Course (two years)

G. Pharmacy (two years) leading to degree of $\mathrm{Ph}$. G.

*No work below Sophomore grade will be given in Civil Engineering during the year 191 t-15.

Write to the REGISTRAR, OREGON AGRICULTURAL COLLEGE, Corvallis, Ore., tor a copy of the College Catalogue. 

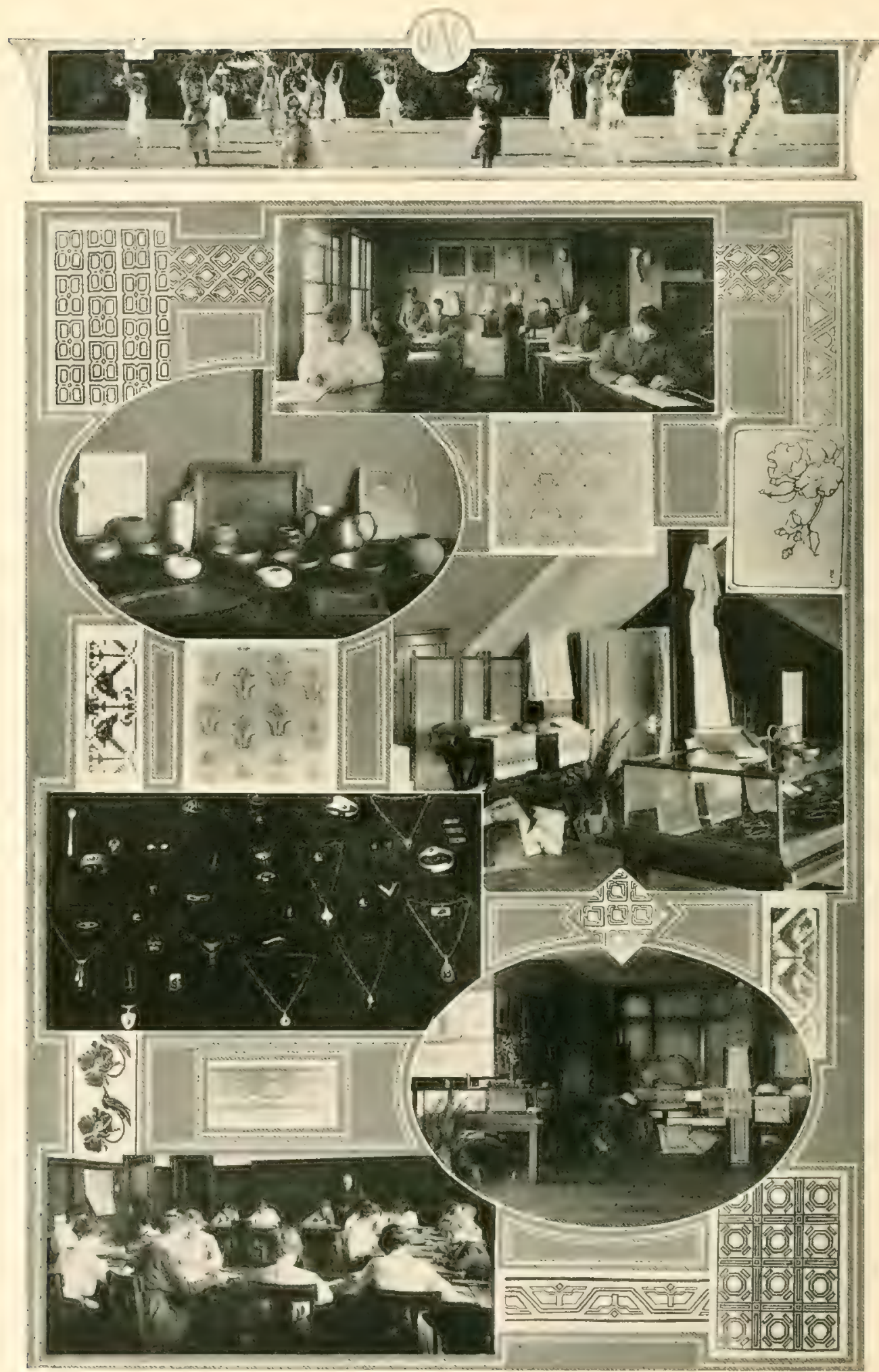

ART AND ARCHITECTURE

SHOWING CLASS EXERCISES, SPECIMENS OF STUDENT HANDIWORK IN POTTERY, JEWELEIRY FTC. AND DETAILS OF DESIGNS WORKED OUT BY STUDENTS FROM ASSIGNED ELEMENTS 



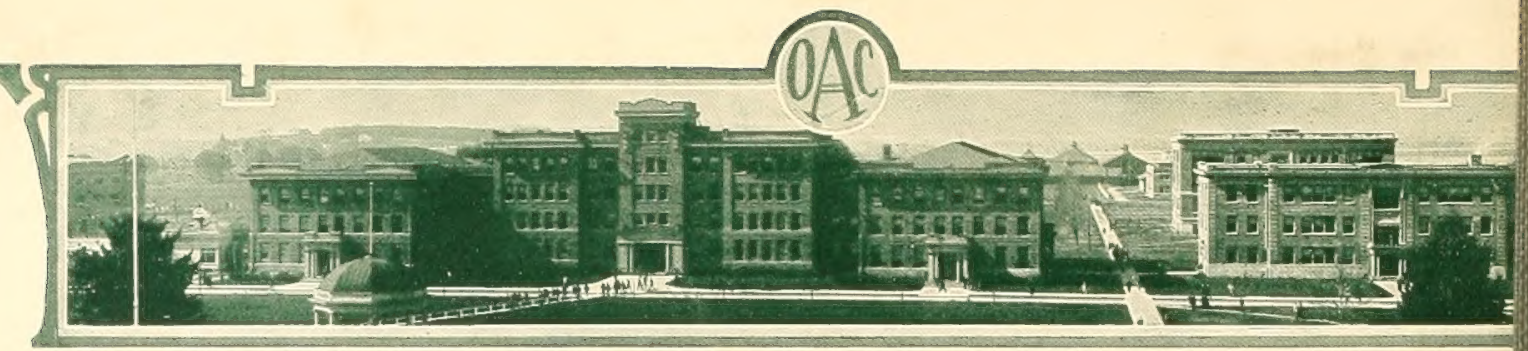

"The Agricultural and Mechanical Colleges have occupied a new field in education. Without precedent or guide, they have had to hew their own way through the thicket of prejudice and suspicion." - President W.J.Kerr, Oregon Agricultural College.

"We have no institutions better adapted to build up a true American citizenship than our Agricultural and Mechanical Colleges, where literary, ethical, scientific, industrial, and military training are blended into a strong, sensible, inspirational scheme of education." -U. S. Senator Knute Nelson, of Minnesota.

"The College aims to bring its advantages as near to all the people as possible; to provide a liberal, thorough, and praclical education. Special emphasis is placed upon the importance of practical training; the application of scientific principles; yet the disciplinary value of education is kept constantly in view. It is recognized that the man and the woman come before the vocation or the profession; and in all the work throughout the institution the object is to develop high ideals of manhood and womanhood, to foster all that makes for right living and good citizenship."-President W.J. Kerr, Oregon Agricultural College.
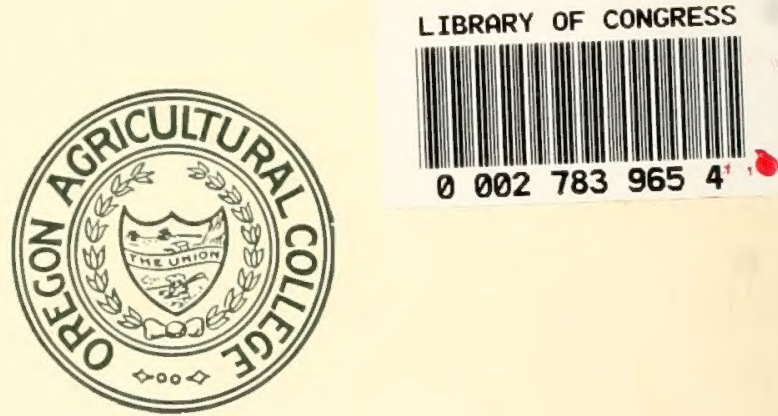

\section{COLLEGE BULLETIN ISSUED MONTHLY NO. TWO HUNDRED JUNE, 1915}

ENTERED AS SECOND CLASS MATTER NOYEMBER 27, 1909, AT THE POST. OFFICE AT CORVALLIS, OREGON, UNDER THE ACT OF JULY 16,1894 
LBRARY OF CONGRESS

| || || || || || ||

00027839654

Hollinger Corp. $\mathrm{pH} 8.5$ 